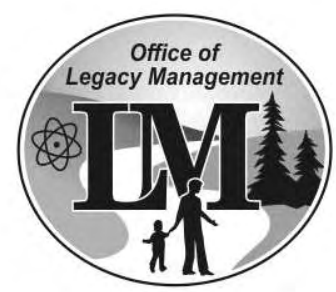

\title{
Post-Closure Inspection and
} Monitoring Report for Corrective Action Unit 417: Central Nevada Test Area Surface, Hot Creek Valley, Nevada, for Calendar Year 2007

September 2008

Rev. 1

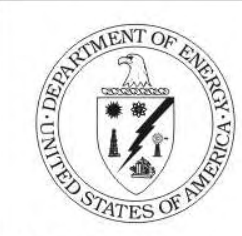

U.S. Department of Energy

\section{Office of Legasy Whangerments}


This page intentionally left blank 


\section{Post-Closure Inspection and Monitoring Report for Corrective Action Unit 417: Central Nevada Test Area Surface, Hot Creek Valley, Nevada}

\section{for Calendar Year 2007}

September 2008

Rev. 1 
This page intentionally left blank 


\section{Contents}

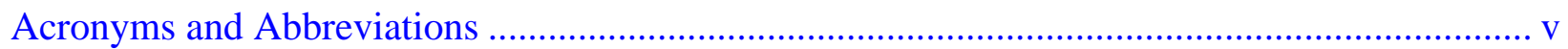

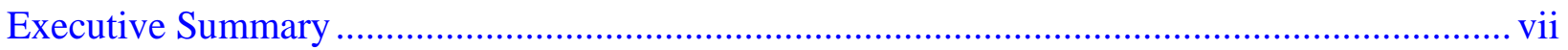

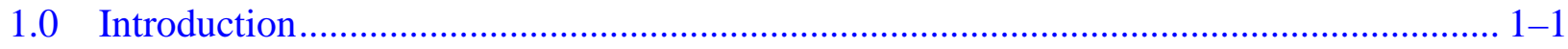

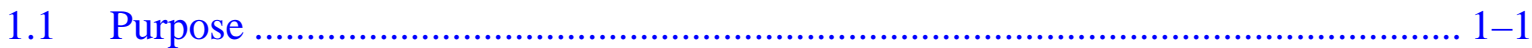

1.2 Site Location and Background................................................................. 1-1

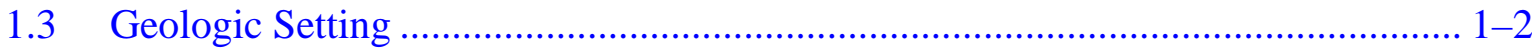

2.0 Post-Closure Monitoring Requirements ................................................................. 2-1

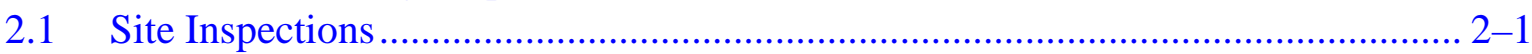

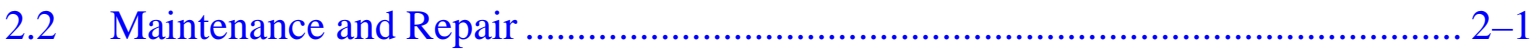

2.3 Soil Moisture Monitoring .................................................................................... 2-2

2.4 Compliance Criteria..................................................................................... 2-4

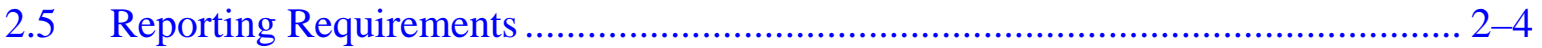

3.0 Site Inspections, Surveys, and Maintenance ....................................................... 3-1

3.1 Annual Site Inspection Results ..................................................................... 3-1

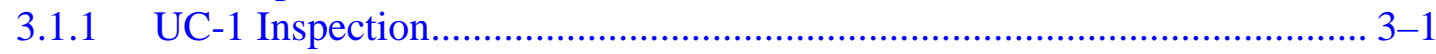

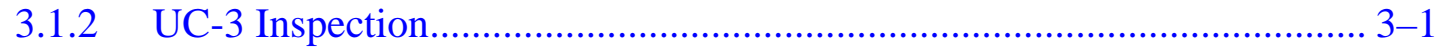

3.1.3 UC-4 Inspection.............................................................................. 3-1

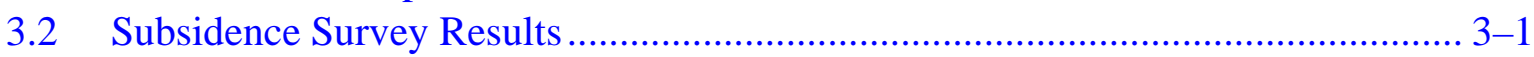

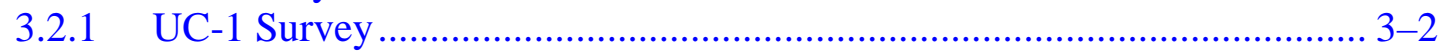

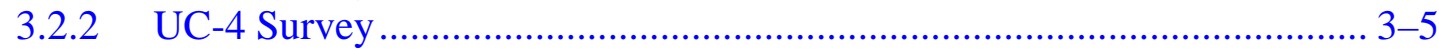

3.3 Vegetation Survey Results............................................................................ 3-7

3.4 Precipitation and Soil Moisture Monitoring Results ......................................... 3-8

3.4.1 UC-1 Soil Moisture Results..................................................................... 3-9

4.0 Summary, Conclusions, and Recommendations................................................. 4-1

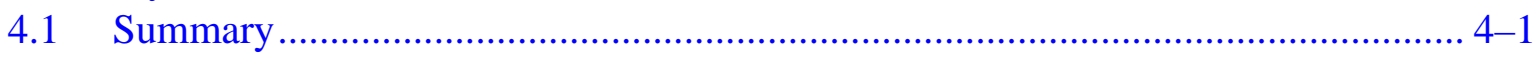

4.2 Conclusions........................................................................................ 4-1

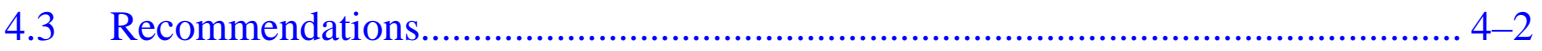

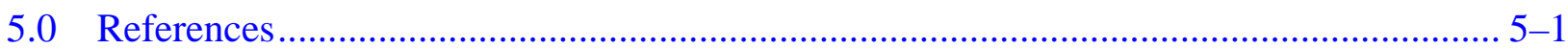




\section{Figures}

Figure 1-1. Central Nevada Test Area Location Map ........................................................ 1-2

Figure 1-2. CAU 417, Central Nevada Test Area Surface Map .......................................... 1-3

Figure 2-1. UC-1 CMP Cover Monitoring Instrumentation ................................................ 2-3

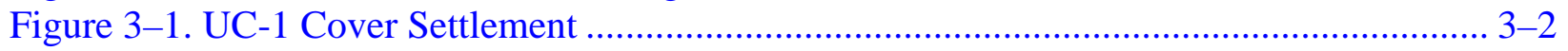

Figure 3-2. UC-4 West and East Monuments ................................................................ 3-5

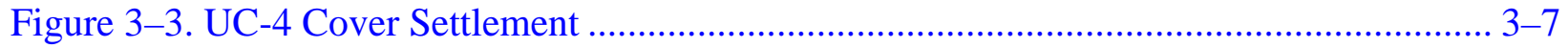

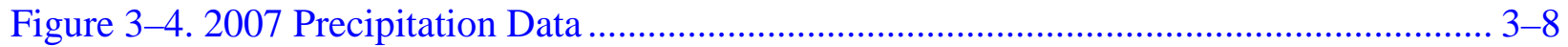

Figure 3-5. UC-1 Soil Moisture Content, East TDR Nest A.................................................. 3-9

Figure 3-6. UC-1 Soil Moisture Content, East TDR Nest B.............................................. 3-10

Figure 3-7. UC-1 Soil Moisture Content, West TDR Nest A ............................................ 3-10

Figure 3-8. UC-1 Soil Moisture Content, West TDR Nest B ............................................ 3-11

\section{Tables}

Table 3-1. UC-1 Monument Elevations and Subsidence ................................................... 3-3

Table 3-2. UC-4 Monument Elevations and Subsidence ................................................... 3-6

\section{Appendixes}

Appendix A Inspection Checklists, Field Notes, and Photographs

Appendix B Historical Moisture Monitoring Data

Appendix C Vegetation Monitoring Report

Appendix D Correspondence and Record of Review 


\section{Acronyms and Abbreviations}

\begin{tabular}{|c|c|}
\hline CAS & Corrective Action Site \\
\hline CAU & Corrective Action Unit \\
\hline $\mathrm{cm}$ & centimeter(s) \\
\hline CMP & Central Mud Pit \\
\hline CNTA & Central Nevada Test Area \\
\hline DOE-LM & U.S. Department of Energy Office of Legacy Management \\
\hline $\mathrm{DOE} / \mathrm{NV}$ & U.S. Department of Energy, Nevada Operations Office \\
\hline FFACO & Federal Facility Agreement and Consent Order \\
\hline $\mathrm{ft}$ & foot (feet) \\
\hline in. & inch(es) \\
\hline $\mathrm{km}$ & kilometer(s) \\
\hline $\mathrm{m}$ & meter(s) \\
\hline mi & mile(s) \\
\hline NDEP & Nevada Division of Environmental Protection \\
\hline NNSA/NSO & $\begin{array}{l}\text { U.S. Department of Energy, National Nuclear Security Administration Nevada } \\
\text { Site Office }\end{array}$ \\
\hline NNSA/NV & $\begin{array}{l}\text { U.S. Department of Energy, National Nuclear Security Administration Nevada } \\
\text { Operations Office }\end{array}$ \\
\hline SOARS & System Operation and Analysis at Remote Sites \\
\hline SM & Subsidence Monument \\
\hline TDR & Time Domain Reflectometry \\
\hline VMC & Volumetric Moisture Content \\
\hline
\end{tabular}


This page intentionally left blank 


\section{Executive Summary}

This report presents data collected during the annual post-closure site inspection conducted at the Central Nevada Test Area Surface Corrective Action Unit (CAU) 417 in May 2007. The annual post-closure site inspection included inspections of the UC-1, UC-3, and UC-4 sites in accordance with the Post-Closure Monitoring Plan provided in the CAU 417 Closure Report (NNSA/NV 2001).

The annual inspection conducted at the UC-1 Central Mud Pit (CMP) indicated the site and soil cover were in good condition. No new cracks or fractures were observed in the soil cover during the annual inspection. A crack on the west portion of the cover was observed during the last quarterly inspection in December 2006. This crack was filled with bentonite as part of the maintenance activities conducted in February 2007 and will be monitored during subsequent annual inspections. The vegetation on the soil cover was adequate but showing signs of the area's ongoing drought. No issues were identified with the CMP fence, gate, or subsidence monuments. New DOE Office of Legacy Management signs with updated emergency phone numbers were installed as part of this annual inspection, no issues were identified with the warning signs and monuments at the other two UC-1 locations.

The annual subsidence survey was conducted at UC-1 CMP and UC-4 Mud Pit C as part of the maintenance activities conducted in February 2007. The results of the subsidence surveys indicate that the covers are performing as expected, and no unusual subsidence was observed.

A vegetation survey of the UC-1 CMP cover and adjacent areas was conducted as part of the annual inspection in May 2007. The vegetation survey indicated that revegetation continues to be successful, although stressed due to the area's prevailing drought conditions. The vegetation should continue to be monitored to document any changes in the plant community and to identify conditions that could potentially require remedial action to maintain a viable vegetation cover on the site. It is suggested that future vegetation surveys be conducted once every 2 years or as needed to help monitor the health of the vegetation.

Precipitation during 2007 was below average; the April through December rainfall total was 3.23 centimeters (1.27 inches). Soil moisture content data show that the UC-1 CMP cover is performing as designed, and evapotranspiration is effectively removing water from the cover.

The inspection at UC-3 indicated that the site is in excellent condition. All monuments and signs showed no displacement, damage, or removal. All warning signs were replaced with new DOE Office of Legacy Management signs with updated emergency phone numbers. No other issues or concerns were identified.

The last quarterly inspection performed at the UC-4 Mud Pit C cover in December 2006, revealed that an erosion rill was forming along the eastern side of the cover. This erosion rill was repaired as part of the maintenance activities conducted in February 2007 and within 90 days of reporting (in compliance with Federal Facility Agreement and Consent Order requirement). Sparse vegetation is present on the cover. The monuments, fence, and gate are in good condition. All warning signs were replaced with new DOE Office of Legacy Management signs with updated emergency phone numbers. No issues were identified with the warning signs and monuments at the other four UC-4 locations. 
This page intentionally left blank 


\subsection{Introduction}

This report presents data collected during the annual post-closure site inspection conducted by the U.S. Department of Energy (DOE) Office of Legacy Management (LM) at the Central Nevada Test Area (CNTA) surface Corrective Action Unit (CAU) 417. This report has been prepared in accordance with the Post-Closure Monitoring Plan contained in the CAU 417 Closure Report (NNSA/NV 2001) and Federal Facility Agreement and Consent Order (FFACO) (FFACO 1996). Responsibility for environmental site restoration of the CNTA was transferred from the DOE Office of Environmental Management to DOE-LM on October 1, 2006. This is the first Post-Closure Inspection Report prepared by DOE-LM for CAU 417.

This report provides an analysis and summary of site inspections, subsidence surveys, meteorological information, and soil moisture monitoring data collected during calendar year 2007. In 2007, the annual site inspection was conducted to document the physical condition of the CAU 417 soil covers, monuments, signs, fencing, and restricted-use areas. Subsidence surveys of the UC-1 Central Mud Pit (CMP) and UC-4 Mud Pit C covers and surveys of the CMP cover vegetation were also conducted. In addition, the UC-1 CMP cover is instrumented to monitor the soil moisture conditions within the upper 1.2 meters $(\mathrm{m})$ (4 feet $[\mathrm{ft}]$ ) of the cover to determine if the cover is performing as designed.

\subsection{Purpose}

The purpose of the post-closure monitoring at CAU 417 is to determine if:

- $\quad$ Maintenance or repairs to the UC-1 CMP or UC-4 Mud Pit C cover, fences, or diversion channels are needed;

- $\quad$ UC-1 CMP or UC-4 Mud Pit C covers are subsiding;

- $\quad$ UC-1 CMP cover is performing as designed;

- Vegetation on the UC-1 CMP cover is healthy;

- Maintenance and repair to the aboveground monuments or warning signs at UC-1, UC-3, and UC-4 are needed; and

- $\quad$ Modifications to the administrative controls are needed.

\subsection{Site Location and Background}

The CNTA is located approximately 22.5 kilometers $(\mathrm{km})(14$ miles [mi]) north of U.S. Highway 6 and approximately 137 km (85 mi) northeast of Tonopah in Nye County, Nevada (Figure 1-1). Three emplacement boreholes, UC-1, UC-3, and UC-4, were drilled at CNTA for underground nuclear weapons testing. The Project Faultless underground nuclear test was conducted in borehole UC-1 at a depth of $975 \mathrm{~m} \mathrm{(3,200} \mathrm{ft)} \mathrm{below} \mathrm{ground} \mathrm{surface} \mathrm{on} \mathrm{January} \mathrm{19,}$ 1968. The other two emplacement boreholes (UC-3 and UC-4) were not used, and no further testing was conducted at CNTA. Boreholes UC-1, UC-3, and UC-4 are located on three separate land withdrawals that range in size from approximately 1 to 1.5 square mi (Figure 1-2). All three land withdrawals are accessible to the public. 


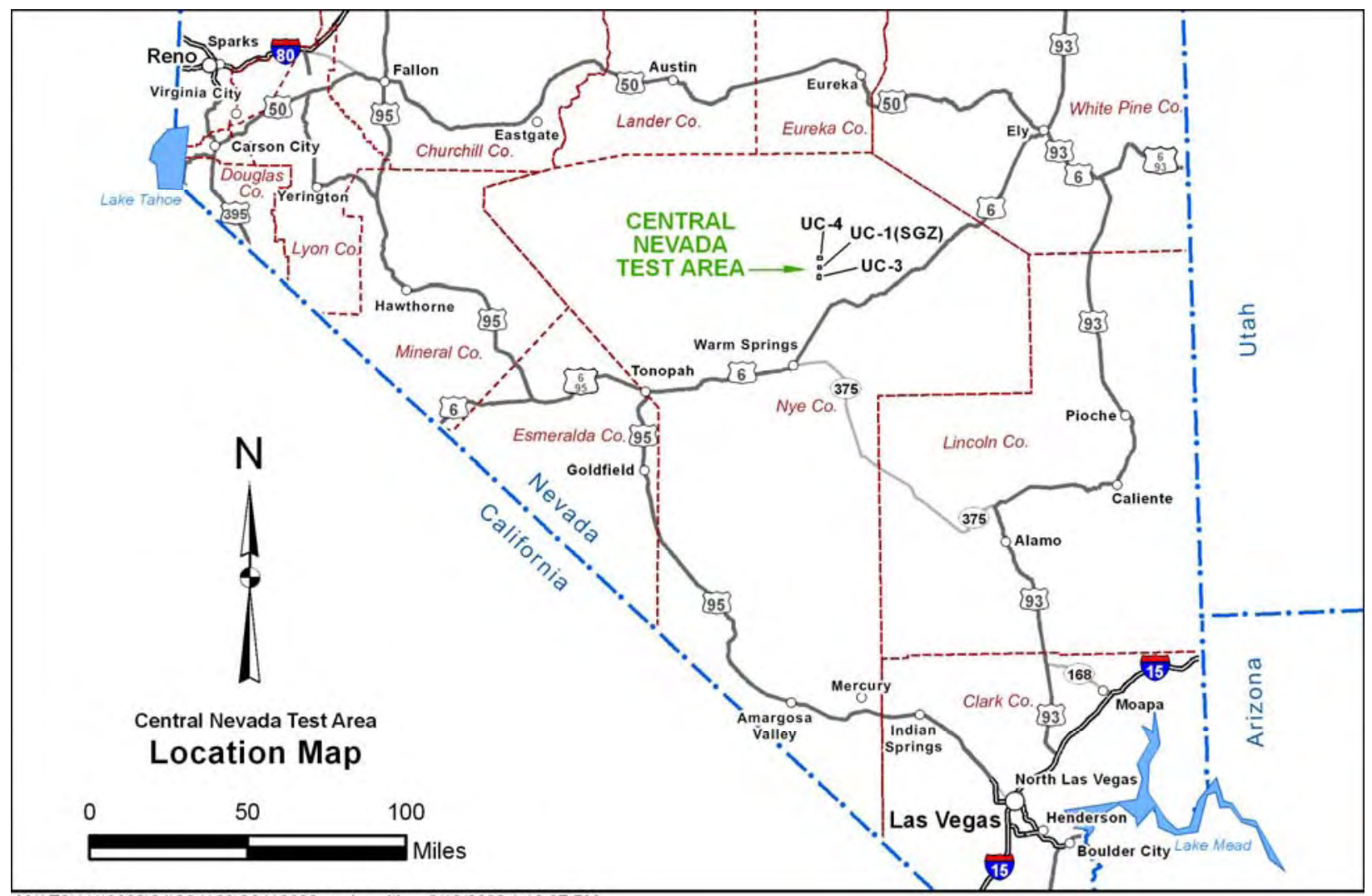

M:ILTS $|11110083104|$ S04166IS0416600.mxd smithw 3/18/2008 1:13:07 PM

Figure 1-1. Central Nevada Test Area Location Map

\subsection{Geologic Setting}

The CNTA is located in the north-central portion of the Hot Creek Valley within the Basin and Range physiographic province. This province consists of regularly spaced, roughly north-south-trending mountain ranges separated by alluvial valleys formed by faulting. The UC-1 site lies at an elevation of 1,860 m (6,100 ft) above mean sea level and is bordered by the Hot Creek Range to the west and the Pancake Range to the east of UC- 1 . The Hot Creek Range is composed of Paleozoic sedimentary rocks and Tertiary volcanic rocks. The Paleozoic rocks comprise sandstones, quartzite, limestone, and dolomite, while the Tertiary volcanic rocks comprise welded tuff, nonwelded bedded tuff, argillized and zeolitized tuff, conglomeratic tuffaceous sandstone, carbonaceous siltstone, and rhyolite (Healey 1968). The alluvium at UC-1 is approximately $730 \mathrm{~m}(2,400 \mathrm{ft})$ thick and is underlain by tuffaceous sediments and zeolitized tuffs to a depth of approximately $998 \mathrm{~m}$ (3,275 ft) (Barnes 1968). The Morey Peak-Hot Creek Caldera is thought to be buried by deposits of tuff and alluvium beneath the northern portion of Hot Creek Valley (Healey 1968). 


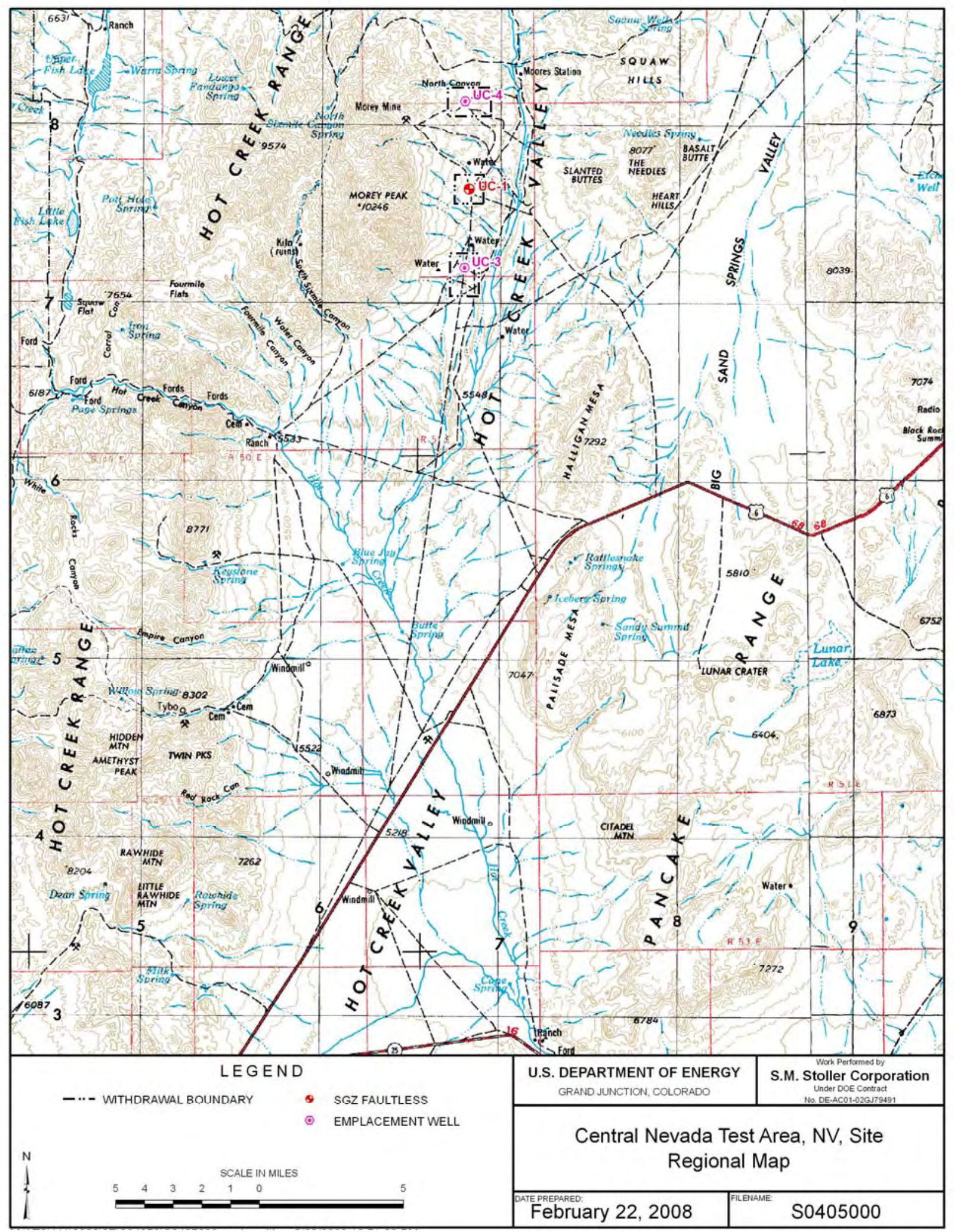

Figure 1-2. CAU 417, Central Nevada Test Area Surface Map 
The Project Faultless test resulted in the subsidence of an irregularly shaped area of approximately 0.9 square kilometer (0.3 square mile). One northeast-trending fault scarp extends beneath the southeastern corner of the UC-1 Mud Pit and cover with as much as $4.6 \mathrm{~m} \mathrm{(15 \textrm {ft } )}$ vertical displacement. Normal drainage patterns were disrupted by the formation of this scarp, so flood diversion channels were constructed to protect the cover and prevent infiltration along the fault scarp (NNSA/NV 2001). Depth to the water table at the UC-1 CMP is approximately $168 \mathrm{~m}$ $(550 \mathrm{ft})$. 


\subsection{Post-Closure Monitoring Requirements}

\subsection{Site Inspections}

Beginning in 2007, the post-closure inspection of CAU 417 is performed annually. The annual site inspection is documented on an inspection checklist, with site photographs and field notes if applicable. The post-closure inspection consists of the following:

- $\quad$ Inspecting the UC-1 CMP cover and UC-4 Mud Pit C cover and fencing, including walking the entire perimeter of the fence and documenting the condition of the barbed wire and chicken wire fencing, warning signs, and entrance gate.

- $\quad$ Inspecting all aboveground monuments, attached warning signs, and affixed survey pins placed at UC-1, UC-3, and UC-4 sites for signs of wear, disturbance, vandalism, animal burrows, and other damage; repair of monuments and attached signs during site inspection visits or, if necessary, at a later time in the calendar year.

- Inspecting the condition of the two subsidence monuments (SMs) on the UC-4 cover and 12 SMs on the UC-1 CMP cover; a subsidence survey of all SMs annually to determine if the covers have subsided.

- $\quad$ Documenting any changes to the cover or fenced area, including, but not limited to, the presence of trash and debris inside the fenced areas, animal burrows on the cover or under the perimeter fence, erosion features on the covers or diversion channels, and any change in the health of the UC-1 CMP cover vegetation.

- Documenting the soil water content profile of the UC-1 CMP cover to determine whether the cover is performing as designed.

- $\quad$ Reporting on the health and stability of the UC-1 CMP cover vegetation.

\subsection{Maintenance and Repair}

If a site inspection detects that either the UC-1 CMP cover or the UC-4 Mud Pit C cover is not in compliance, or if conditions requiring major repairs are noted, or if any other problems in critical areas are noted, the issue will be evaluated and reported to the Nevada Division of Environmental Protection (NDEP) within 60 days of detection (in compliance with the FFACO). The following guidelines apply to CAU 417 maintenance and repairs:

- $\quad$ Cracks, settling features, erosion rills, and animal burrows larger than 15 centimeters (cm) (6 inches [in.]) deep that extend $1 \mathrm{~m}$ (3 ft) or more and that do not compromise the UC-1 CMP or UC-4 Mud Pit C covers will be evaluated and repaired within 90 days of detection.

- $\quad$ Noncritical cracks, settling features, erosion rills, and animal burrows less than $15 \mathrm{~cm}$

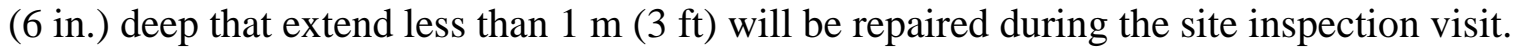

- $\quad$ Damage to the fencing surrounding the UC-1 CMP cover or the UC-4 Mud Pit C cover, warning signs, or monuments will be evaluated and repaired within 90 days of detection.

- $\quad$ Major damage to use-restriction warning signs or monuments will be evaluated and repaired during subsequent site inspections.

- $\quad$ All repair work will preserve the original as-built design and will be documented in the annual post-closure report. 


\subsection{Soil Moisture Monitoring}

The CNTA UC-1 CMP monolayer cover is designed to limit infiltration of moisture into the disposal unit by evapotranspiration from vegetation that was established on the cover for that purpose. The cover performance is monitored using time domain reflectometry (TDR) sensor data to provide a profile of the water content in the cover. The soil water content profile will determine whether the cover is performing as designed and if it is in compliance with the closure plan and agreements.

The soil moisture content is obtained using a Campbell Scientific TDR-100 and a data logger housed in an instrument vault located just off the southern edge of the cover. TDR sensors were buried in the cover at two locations during cover construction. At both locations, two TDR sensors were placed at each of the following depths: $0.15,0.46,0.76$, and $1.07 \mathrm{~m}(0.5,1.5,2.5$, and $3.5 \mathrm{ft}$ ) below the surface of the cover (Figure 2-1). The TDR nests are located approximately $48 \mathrm{~m}(157 \mathrm{ft})$ northwest and $48 \mathrm{~m}(157 \mathrm{ft})$ northeast of the instrument vault. Data are collected daily from each TDR sensor and stored in a data logger located in the instrument vault. The stored TDR and precipitation data are automatically transmitted via a satellite uplink to a Geostationary Operational Environmental Satellite for relay to the National Oceanic and Atmospheric Administration’s Wallops Island, Virginia, earth station.

The data are automatically retrieved from the earth station daily through the Internet and imported into the System Operation and Analysis at Remote Sites (SOARS) system. The post-processing software used by SOARS automatically produces graphs and tables, and the data are automatically backed up daily.

The TDR probes were calibrated to volumetric moisture content (VMC) using a "dry-down" method with native soil and the full cable length. The results of the calibration indicated that a site-specific calibration equation should be used instead of the standard Topp equation. It was also found that because of the long cable lengths and soil conductivities, the TDR reflection end points were extremely flat under saturated and near-saturated conditions, resulting in unreliable data in these regions.

A fourth-order polynomial fit of the calibration data over the range of 5 to 35 percent VMC yielded the following calibration equation:

$$
\operatorname{VMC}(\%)=-308.701+373.1803(\mathrm{~L} / \mathrm{L})-163.644(\mathrm{~L} / \mathrm{L})^{2}+31.82972(\mathrm{~L} / \mathrm{L})^{3}-2.25548(\mathrm{~L} / \mathrm{L})^{4}
$$

Where $\mathrm{L} / \mathrm{L}$ is the ratio of trace length to probe length as recorded by the data logger. 


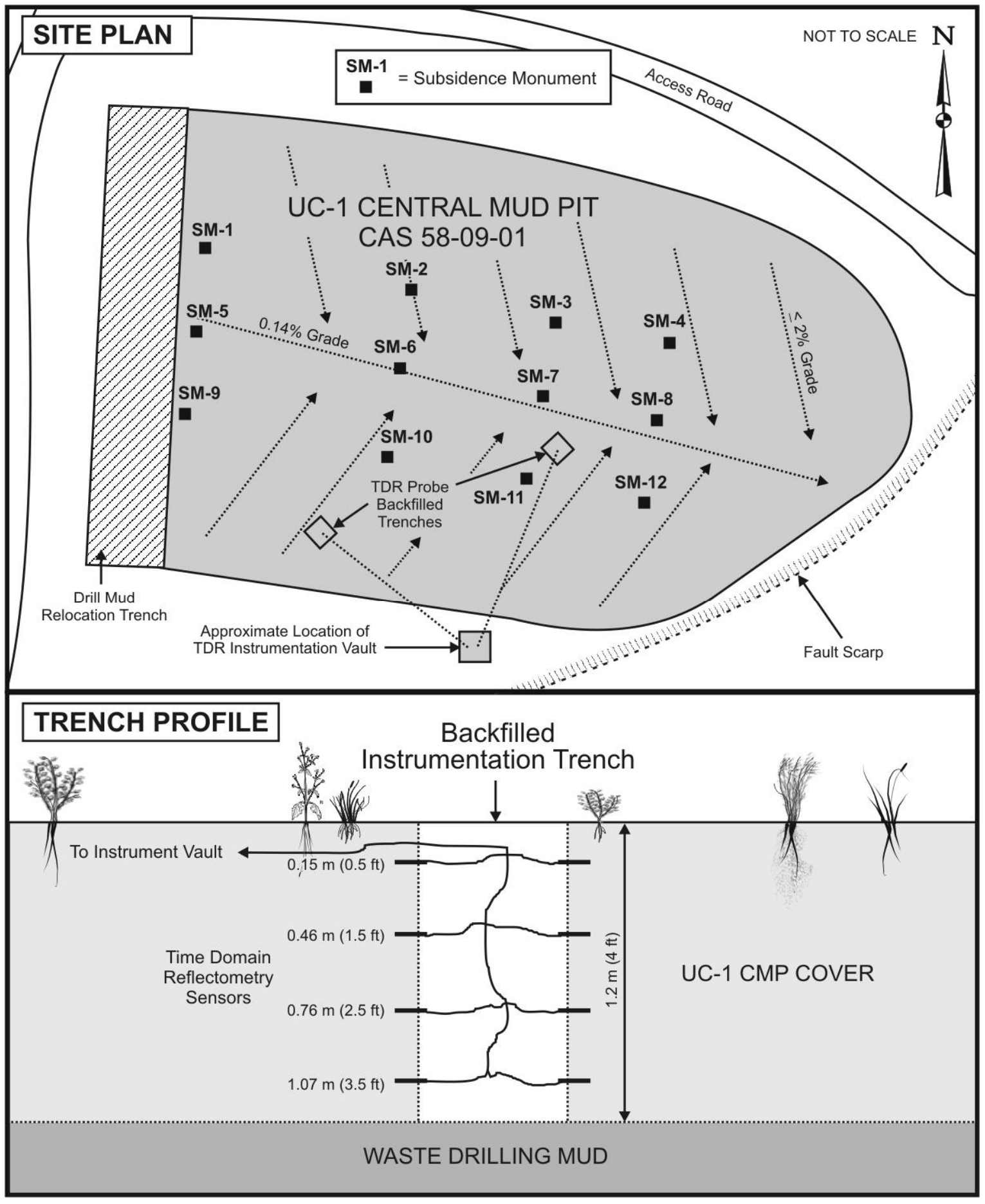

Figure 2-1. UC-1 CMP Cover Monitoring Instrumentation 


\subsection{Compliance Criteria}

The point of compliance for the UC-1 CMP cover is the depth of the deepest TDR soil moisture probe, which is approximately $1.07 \mathrm{~m}(3.5 \mathrm{ft})$ below ground surface. Cover compliance will be based on the soil moisture content of the cover once steady-state conditions are reached. Cover performance modeling presented in the CAU 417 Corrective Action Plan (DOE/NV 2000) predicted that steady-state conditions will be achieved within 10 years of cover construction, which was completed in September of 2000. At that time, it is expected that soil moisture trigger values will be agreed upon as compliance criteria with NDEP.

If soil moisture data indicate that the cover is not operating according to established compliance criteria, NDEP will be notified of the noncompliance within 14 days. After NDEP has been notified of noncompliance, a work plan will be submitted to NDEP within 90 days outlining the proposed remediation/investigation plan. All corrective actions will be documented in the annual Post-Closure Inspection and Monitoring Report.

\subsection{Reporting Requirements}

All inspection and maintenance activities conducted during the year are documented and included in an annual inspection and monitoring report. The annual post-closure report is submitted by DOE-LM to NDEP and includes the following information:

- $\quad$ A brief narrative and discussion of all post-closure inspection activities and observations;

- $\quad$ Copies of all completed inspection checklists and maintenance records;

- $\quad$ UC-1 CMP soil moisture content profiles through the previous year;

- $\quad$ Subsidence survey data; and

- $\quad$ Specific recommendations for nonstandard maintenance or changes in post-closure requirements.

All closure and post-closure monitoring documentation is maintained in project files and is available on request. 


\subsection{Site Inspections, Surveys, and Maintenance}

\subsection{Annual Site Inspection Results}

The annual inspection of all three sites was performed concurrently with the vegetation survey on May 15, 2007. Minor corrective actions to UC-1 and UC-4 were performed on February 22, 2007, concurrently with the survey of SMs at UC-1 and UC-4. Copies of the inspection checklists and photographs for calendar year 2007 are included in Appendix A. A summary of the inspection results is provided in the following sections.

\subsubsection{UC-1 Inspection}

The CMP site was in good condition. All locks, fencing, and signs were in good order. The vegetation on the cover was drought-stressed. No issues were identified with the monuments, and no maintenance or repairs were recommended. All other signs and monuments at Mud Pits A and $\mathrm{E}$ were in excellent condition. All warning signs were replaced with new DOE Office of Legacy Management signs with updated emergency phone numbers.

Minor maintenance activities were performed at UC-1 in 2007. A crack in the cover showing lateral expansion was observed during an inspection conducted in December 2006 and was repaired in February 2007.

\subsubsection{UC-3 Inspection}

The site was in excellent condition. No issues were identified with the monuments or signs, and no maintenance or repairs were recommended. All warning signs were replaced with new DOE Office of Legacy Management signs with updated emergency phone numbers.

No issues or concerns were found during the inspections in 2007; therefore, no maintenance or repairs were performed.

\subsubsection{UC-4 Inspection}

The Mud Pit C fence and SMs were in good condition. A pin on the gate lock hasp was missing, but it does not affect the integrity of the locking mechanism. No erosion or subsidence was observed on the cover. Mud Pits A, B, and D were in excellent condition, and no issues were identified with Area S or Area X. All warning signs were replaced with new DOE Office of Legacy Management signs with updated emergency phone numbers. The overall condition of the site was good, and no issues were noted that affected the integrity of the cover and appurtenances.

An erosion rill located on the northeast corner of the cover was found during the December 2006 inspection and repaired in February 2007.

\subsection{Subsidence Survey Results}

Surveys of the SMs for UC-1 and UC-4 were performed on February 22, 2007. A summary of the survey results is provided in the following sections. 


\subsubsection{UC-1 Survey}

Twelve SMs were installed on the UC-1 CMP cover to provide elevation control for measuring subsidence of the cover over both the CMP and the relocation trench (NNSA/NV 2001). These SMs are shown on Figure 2-1. The baseline subsidence survey was completed on December 4, 2000, and is used as the reference survey to calculate subsidence for each subsequent survey. Biannual subsidence monitoring, started in 2002, was replaced by annual subsidence monitoring beginning in 2007. The UC-1 baseline survey locations and all elevations are provided in Table 3-1 and are presented in graphical form in Figure 3-1.

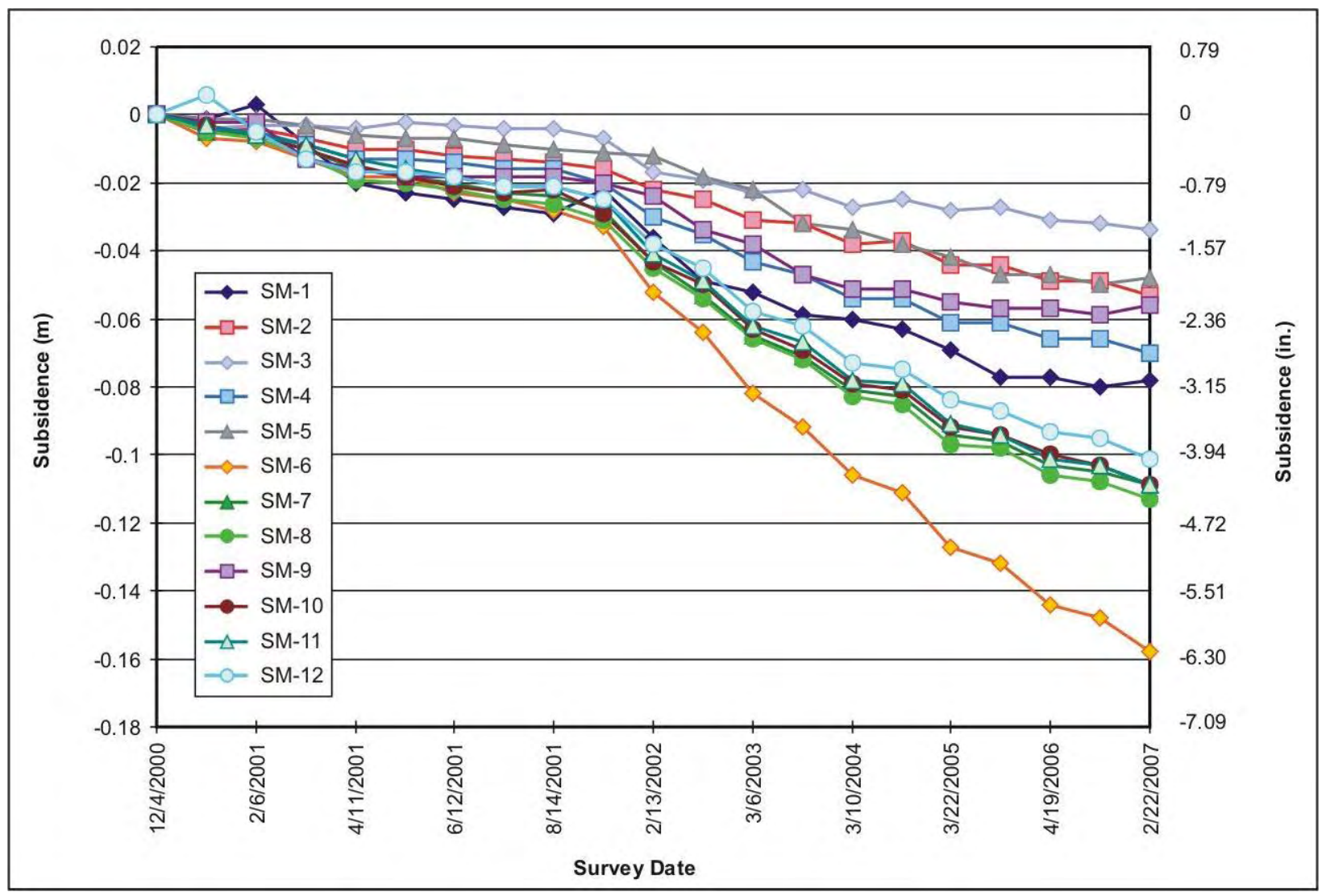

Figure 3-1. UC-1 Cover Settlement

The degree of settling in both the relocation trench and the CMP is within the predicted range and shows no unusual subsidence. The data collected over the CMP section of the cover indicate that the largest subsidence is located along the centerline of the CMP, including SM-6, SM-7, and SM-8. This was expected because of the thicker layer of underlying mud in this area. The northern monuments, SM-2, SM-3, and SM-4, along with the western-most monument, SM-5, show the least subsidence because of the thinner layer of underlying mud along this margin of the cover. The greatest degree of settling continues to be on SM-6, which has subsided a total of $15.8 \mathrm{~cm}$ (6.2 in.) since the baseline survey in December 2000. 


\begin{tabular}{|c|c|c|c|c|c|c|c|c|c|c|c|c|}
\hline \multirow[b]{2}{*}{ Date } & \multicolumn{12}{|c|}{$\begin{array}{l}\begin{array}{c}\text { Elevation at Top of Monument } \\
\text { Subsidence }(m)\end{array} \\
\end{array}$} \\
\hline & $\begin{array}{c}\text { SM-1 } \\
\text { N 6,430,874.2869 } \\
\text { E 539,588.2339 } \\
\end{array}$ & $\begin{array}{c}\text { SM-2 } \\
\text { N 6,430,863.3239 } \\
\text { E 539,644.8195 } \\
\end{array}$ & \begin{tabular}{|c|} 
SM-3 \\
N 6,430,855.2553 \\
E 539,684.3327 \\
\end{tabular} & \begin{tabular}{|c|} 
SM-4 \\
N 6,430,849.7763 \\
E 539,715.7991 \\
\end{tabular} & \begin{tabular}{|c|} 
SM-5 \\
N 6,430,852.0243 \\
E 539,585.4651 \\
\end{tabular} & \begin{tabular}{|c|} 
SM-6 \\
N 6,430,841.7590 \\
E 539,641.4674 \\
\end{tabular} & \begin{tabular}{|c|} 
SM-7 \\
N 6,430,834.5289 \\
E 539,680.5243 \\
\end{tabular} & \begin{tabular}{|c|} 
SM-8 \\
N 6,430,828.6994 \\
E 539,712.4350 \\
\end{tabular} & \begin{tabular}{|c|} 
SM-9 \\
N 6,430,828.8720 \\
E 539,582.4750 \\
\end{tabular} & \begin{tabular}{|c|} 
SM-10 \\
$N$ 6,430,818.6353 \\
$E 539,638.2030$ \\
\end{tabular} & \begin{tabular}{|c|} 
SM-11 \\
N 6,430,812.8276 \\
E 539,676.0839 \\
\end{tabular} & \begin{tabular}{|c|} 
SM-12 \\
N 6,430,806.7973 \\
E 539,708.9837 \\
\end{tabular} \\
\hline \multirow{2}{*}{$\begin{array}{c}\text { 12/04/2000 } \\
\text { Baseline }\end{array}$} & 1836.604 & 1835.154 & \begin{tabular}{|l|}
1834.995 \\
\end{tabular} & \begin{tabular}{|l|}
1834.854 \\
\end{tabular} & \begin{tabular}{|l|}
1836.541 \\
\end{tabular} & \begin{tabular}{|l|}
1834.887 \\
\end{tabular} & \begin{tabular}{|l|}
1834.709 \\
\end{tabular} & \begin{tabular}{|l|}
1834.681 \\
\end{tabular} & \begin{tabular}{|l|}
1836.547 \\
\end{tabular} & \begin{tabular}{|l|}
1834.943 \\
\end{tabular} & \begin{tabular}{|l|}
1834.744 \\
\end{tabular} & 1834.635 \\
\hline & 0 & 0 & 0 & 0 & 0 & 0 & 0 & 0 & 0 & 0 & 0 & 0 \\
\hline \multirow{2}{*}{ 01/10/2001 } & 1836.603 & 1835.149 & 1834.991 & 1834.850 & 1836.540 & 1834.880 & 1834.704 & 1834.676 & 1836.545 & 1834.940 & 1834.741 & 1834.641 \\
\hline & -0.001 & -0.005 & -0.004 & -0.004 & -0.001 & -0.007 & -0.005 & -0.005 & -0.002 & -0.003 & -0.003 & 0.006 \\
\hline \multirow{2}{*}{ 2/06/2001 } & 1836.607 & 1835.150 & 1834.992 & 1834.849 & 1836.540 & 1834.879 & 1834.703 & 1834.674 & 1836.545 & 1834.937 & 1834.738 & 1834.630 \\
\hline & 0.003 & -0.004 & -0.003 & -0.005 & -0.001 & -0.008 & -0.006 & -0.007 & -0.002 & -0.006 & -0.006 & -0.005 \\
\hline \multirow{2}{*}{ 03/13/2001 } & 1836.595 & 1835.147 & 1834.992 & 1834.845 & 1836.538 & 1834.874 & 1834.699 & 1834.669 & 1836.534 & 1834.933 & 1834.735 & 1834.622 \\
\hline & -0.009 & -0.007 & -0.003 & -0.009 & -0.003 & -0.013 & -0.010 & -0.012 & -0.013 & -0.010 & -0.009 & -0.013 \\
\hline \multirow{2}{*}{ 04/11/2001 } & 1836.584 & 1835.144 & 1834.991 & 1834.841 & 1836.535 & 1834.869 & 1834.693 & 1834.662 & 1836.531 & 1834.928 & 1834.731 & 1834.618 \\
\hline & -0.020 & -0.010 & -0.004 & -0.013 & -0.006 & -0.018 & -0.016 & -0.019 & -0.016 & -0.015 & -0.013 & -0.017 \\
\hline \multirow{2}{*}{ 05/09/2001 } & 1836.581 & 1835.144 & 1834.993 & 1834.841 & 1836.534 & 1834.869 & 1834.691 & 1834.661 & 1836.529 & 1834.925 & 1834.728 & 1834.618 \\
\hline & -0.023 & -0.010 & -0.002 & -0.013 & -0.007 & -0.018 & -0.018 & -0.020 & -0.018 & -0.018 & -0.016 & -0.017 \\
\hline \multirow{2}{*}{ 6/12/2001 } & 1836.579 & 1835.142 & 1834.992 & 1834.840 & 1836.534 & 1834.864 & 1834.689 & 1834.659 & 1836.529 & 1834.922 & 1834.726 & 1834.617 \\
\hline & -0.025 & -0.012 & -0.003 & -0.014 & -0.007 & -0.023 & -0.020 & -0.022 & -0.018 & -0.021 & -0.018 & -0.018 \\
\hline \multirow{2}{*}{ 07/18/2001 } & 1836.577 & 1835.141 & 1834.991 & 1834.838 & 1836.532 & 1834.862 & 1834.686 & 1834.656 & 1836.529 & 1834.920 & 1834.723 & 1834.614 \\
\hline & -0.027 & -0.013 & -0.004 & -0.016 & -0.009 & -0.025 & -0.023 & -0.025 & -0.018 & -0.023 & -0.021 & -0.021 \\
\hline \multirow{2}{*}{ 08/14/2001 } & 1836.575 & 1835.140 & 1834.991 & 1834.838 & 1836.531 & 1834.859 & 1834.685 & 1834.655 & 1836.529 & 1834.921 & 1834.723 & 1834.614 \\
\hline & -0.029 & -0.014 & -0.004 & -0.016 & -0.010 & -0.028 & -0.024 & -0.026 & -0.018 & -0.022 & -0.021 & -0.021 \\
\hline \multirow{2}{*}{ 09/12/2001 } & 1836.582 & 1835.138 & 1834.988 & 1834.834 & 1836.530 & 1834.854 & 1834.681 & 1834.650 & 1836.527 & 1834.914 & 1834.719 & 1834.610 \\
\hline & -0.022 & -0.016 & -0.007 & -0.020 & -0.011 & -0.033 & -0.028 & -0.031 & -0.020 & -0.029 & -0.025 & -0.025 \\
\hline \multirow{2}{*}{ 02/13/2002 } & 1836.568 & 1835.132 & 1834.978 & 1834.824 & 1836.529 & 1834.835 & 1834.666 & 1834.636 & 1836.523 & 1834.900 & 1834.703 & 1834.597 \\
\hline & -0.036 & -0.022 & -0.017 & -0.030 & -0.012 & -0.052 & -0.043 & -0.045 & -0.024 & -0.043 & -0.041 & -0.038 \\
\hline \multirow{2}{*}{ 08/26/2002 } & 1836.555 & 1835.129 & 1834.976 & 1834.819 & 1836.523 & 1834.823 & 1834.656 & 1834.627 & 1836.513 & 1834.893 & 1834.695 & 1834.590 \\
\hline & -0.049 & -0.025 & -0.019 & -0.035 & -0.018 & -0.064 & -0.053 & -0.054 & -0.034 & -0.050 & -0.049 & -0.045 \\
\hline \multirow{2}{*}{ 03/06/2003 } & 1836.552 & 1835.123 & 1834.972 & 1834.811 & 1836.519 & 1834.805 & 1834.644 & 1834.615 & 1836.509 & 1834.880 & 1834.682 & 1834.577 \\
\hline & -0.052 & -0.031 & -0.023 & -0.043 & -0.022 & -0.082 & -0.065 & -0.066 & -0.038 & -0.063 & -0.062 & -0.058 \\
\hline \multirow{2}{*}{ 09/26/2003 } & 1836.545 & 1835.122 & $\begin{array}{l}1834.973 \\
\end{array}$ & 1834.807 & 1836.509 & 1834.795 & $\begin{array}{l}1834.638 \\
\end{array}$ & $\begin{array}{l}1834.609 \\
\end{array}$ & 1836.500 & $\begin{array}{l}1834.874 \\
\end{array}$ & 1834.677 & 1834.573 \\
\hline & -0.059 & -0.032 & -0.022 & -0.047 & -0.032 & -0.092 & -0.071 & -0.072 & -0.047 & -0.069 & -0.067 & -0.062 \\
\hline \multirow{2}{*}{ 03/10/2004 } & 1836.544 & 1835.116 & $\begin{array}{l}1834.968 \\
\end{array}$ & 1834.800 & 1836.507 & 1834.781 & $\begin{array}{l}1834.628 \\
\end{array}$ & $\begin{array}{ll}1834.598 \\
\end{array}$ & $\begin{array}{l}1836.496 \\
\end{array}$ & 1834.864 & 1834.666 & 1834.562 \\
\hline & -0.060 & -0.038 & -0.027 & -0.054 & -0.034 & -0.106 & -0.081 & -0.083 & -0.051 & -0.079 & -0.078 & -0.073 \\
\hline \multirow{2}{*}{ 09/15/2004 } & \begin{tabular}{|l|l}
1836.541 \\
\end{tabular} & 1835.117 & $\begin{array}{l}1834.970 \\
\end{array}$ & $\begin{array}{l}1834.800 \\
\end{array}$ & $\begin{array}{l}1836.503 \\
\end{array}$ & $\begin{array}{l}1834.776 \\
\end{array}$ & $\begin{array}{l}1834.626 \\
\end{array}$ & $\begin{array}{l}1834.596 \\
\end{array}$ & $\begin{array}{l}1836.496 \\
\end{array}$ & $\begin{array}{l}1834.862 \\
\end{array}$ & 1834.665 & 1834.560 \\
\hline & -0.063 & -0.037 & -0.025 & -0.054 & -0.038 & -0.111 & -0.083 & -0.085 & -0.051 & -0.081 & -0.079 & -0.075 \\
\hline \multirow{2}{*}{$03 / 22 / 2005$} & 1836.535 & $\begin{array}{l}1835.110 \\
\end{array}$ & $\begin{array}{l}1834.967 \\
\end{array}$ & $\begin{array}{l}1834.793 \\
\end{array}$ & $\begin{array}{l}1836.499 \\
\end{array}$ & 1834.760 & 1834.615 & $\begin{array}{l}1834.584 \\
\end{array}$ & $\begin{array}{l}1836.492 \\
\end{array}$ & $\begin{array}{l}1834.851 \\
\end{array}$ & 1834.653 & $\begin{array}{l}1834.551 \\
\end{array}$ \\
\hline & -0.069 & -0.044 & -0.028 & -0.061 & -0.042 & -0.127 & -0.094 & -0.097 & -0.055 & -0.092 & -0.091 & -0.084 \\
\hline \multirow{2}{*}{ 09/21/2005 } & 1836.527 & 1835.110 & $\begin{array}{l}1834.968 \\
\end{array}$ & $\begin{array}{l}1834.793 \\
\end{array}$ & $\begin{array}{l}1836.494 \\
\end{array}$ & 1834.755 & 1834.613 & 1834.583 & 1836.490 & $\begin{array}{l}1834.849 \\
\end{array}$ & 1834.650 & $\begin{array}{l}1834.548 \\
\end{array}$ \\
\hline & -0.077 & -0.044 & -0.027 & -0.061 & $\begin{array}{l}-0.047 \\
\end{array}$ & -0.132 & -0.096 & -0.098 & -0.057 & -0.094 & -0.094 & -0.087 \\
\hline \multirow{2}{*}{ 04/19/2006 } & $\begin{array}{l}1836.527 \\
\end{array}$ & 1835.105 & $\begin{array}{l}1834.964 \\
\end{array}$ & $\begin{array}{l}1834.788 \\
\end{array}$ & $\begin{array}{l}1836.494 \\
\end{array}$ & $\begin{array}{l}1834.743 \\
\end{array}$ & $\begin{array}{l}1834.606 \\
\end{array}$ & 1834.575 & 1836.490 & $\begin{array}{l}1834.843 \\
\end{array}$ & 1834.643 & 1834.542 \\
\hline & -0.077 & -0.049 & -0.031 & -0.066 & -0.047 & -0.144 & -0.103 & -0.106 & -0.057 & -0.100 & -0.101 & -0.093 \\
\hline $09 / 19 / 2006$ & $\begin{array}{l}1836.524 \\
\end{array}$ & 1835.105 & $\begin{array}{l}1834.963 \\
\end{array}$ & $\begin{array}{l}1834.788 \\
\end{array}$ & \begin{tabular}{|l|l}
1836.491 \\
\end{tabular} & $\begin{array}{l}1834.739 \\
\end{array}$ & $\begin{array}{l}1834.604 \\
\end{array}$ & $\begin{array}{l}1834.573 \\
\end{array}$ & $\begin{array}{l}1836.488 \\
\end{array}$ & $\begin{array}{l}1834.840 \\
\end{array}$ & $\begin{array}{l}1834.641 \\
\end{array}$ & $\begin{array}{l}1834.54 \\
\end{array}$ \\
\hline 09/19/2006 & -0.08 & $\begin{array}{l}-0.049 \\
\end{array}$ & $\begin{array}{l}-0.032 \\
\end{array}$ & $\begin{array}{l}-0.066 \\
\end{array}$ & -0.05 & -0.148 & -0.105 & -0.108 & -0.059 & -0.103 & -0.103 & -0.095 \\
\hline $02 / 22 / 2007$ & $\begin{array}{l}1836.526 \\
\end{array}$ & 1835.101 & $\begin{array}{l}1834.961 \\
\end{array}$ & $\begin{array}{l}1834.784 \\
\end{array}$ & 1836.493 & $\begin{array}{l}1834.729 \\
\end{array}$ & 1834.600 & $\begin{array}{l}1834.568 \\
\end{array}$ & 1836.491 & 1834.834 & 1834.635 & 1834.534 \\
\hline $02 / 2212001$ & -0.078 & -0.053 & -0.034 & -0.070 & -0.048 & -0.158 & -0.109 & -0.113 & -0.056 & -0.109 & -0.109 & -0.101 \\
\hline
\end{tabular}

a Vertical datum: National Geodetic Vertical Datum of 1929 in meters
b Horizontal datum: U.S. State Plane 1983; vertical datum: Nations

${ }^{\mathrm{b}}$ Horizontal datum: U.S. State Plane 1983; vertical datum: National Geodetic Vertical Datum of 1929

$\mathrm{E}=$ easting 
This page intentionally left blank 


\subsubsection{UC-4 Survey}

Two permanent SMs (west and east monuments) were installed in the cover to provide elevation control for measuring the subsidence of the cover. These SMs are shown on Figure 3-2. The baseline subsidence survey was completed on October 12, 1999, and is used as the reference survey to calculate subsidence. The UC-4 baseline survey locations and all elevations are provided in Table 3-2 and are presented in graphical form in Figure 3-3. Settling of the west monument is still slightly greater than the predicted settling of $5 \mathrm{~cm}$ (2 in.); the total subsidence is $6.6 \mathrm{~cm}$ (2.6 in.) since the baseline survey in October 1999. The east monument has subsided a total of $3.1 \mathrm{~cm}$ (1.2 in.) since the baseline survey. The largest changes occurred within the first year.

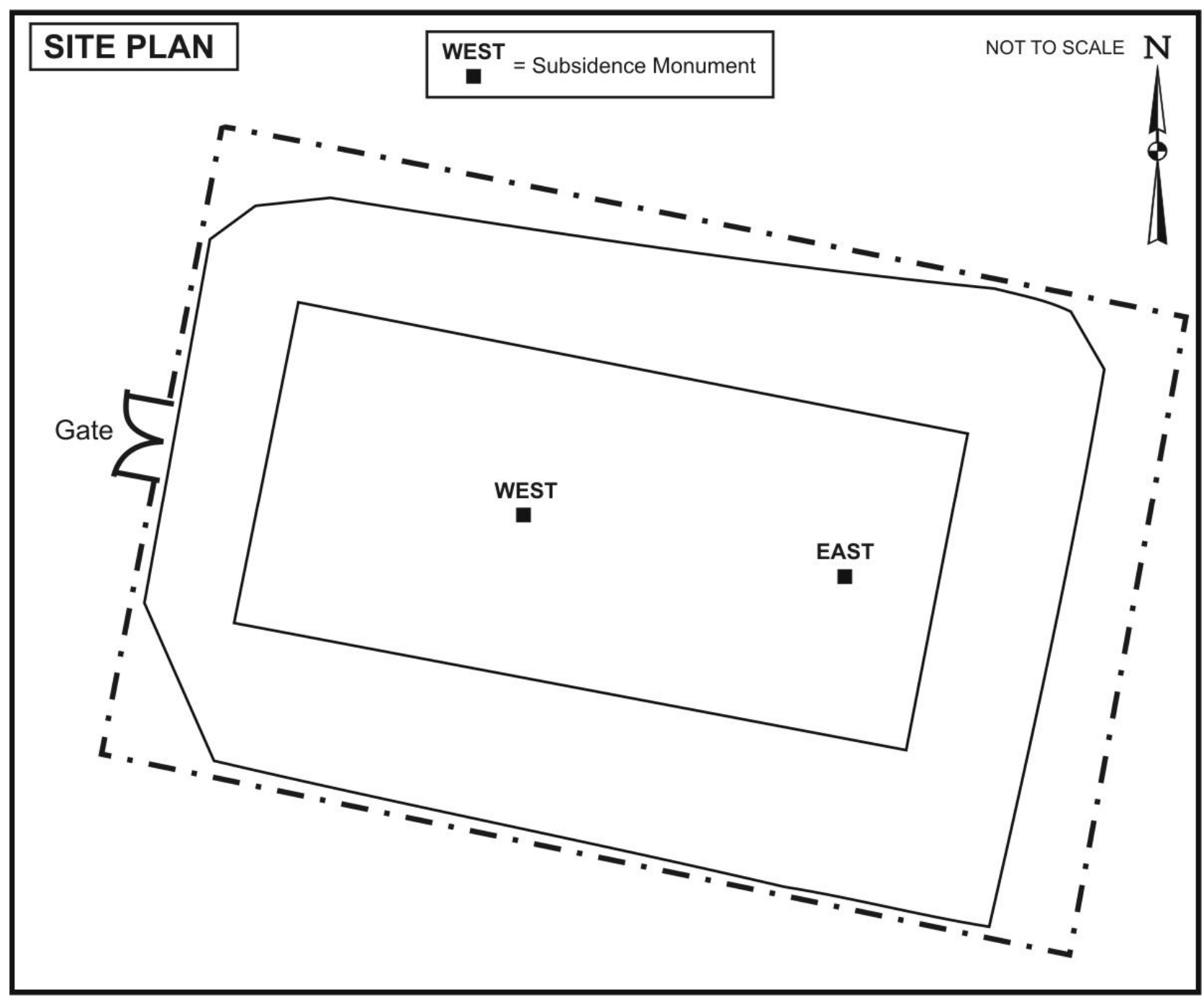

Figure 3-2. UC-4 West and East Monuments 
Table 3-2. UC-4 Monument Elevations and Subsidence

\begin{tabular}{|c|c|c|}
\hline \multirow[b]{2}{*}{ Date } & \multicolumn{2}{|c|}{$\frac{\text { Elevation at Top of Monument }^{\mathrm{a}, \mathrm{b}}}{\text { Subsidence }(\mathrm{m})}$} \\
\hline & $\begin{array}{c}\text { West Monument } \\
\text { N 6,435,982.965 } \\
\text { E 538,966.436 }\end{array}$ & $\begin{array}{c}\text { East Monument } \\
\text { N 6,435,978.404 } \\
\text { E 538,992.231 }\end{array}$ \\
\hline \multirow{2}{*}{$\begin{array}{c}\text { 10/12/1999 } \\
\text { Baseline }\end{array}$} & 1999.269 & 1999.062 \\
\hline & 0.000 & 0.000 \\
\hline \multirow{2}{*}{ 11/29/1999 } & 1999.260 & 1999.056 \\
\hline & -0.009 & -0.006 \\
\hline \multirow{2}{*}{$01 / 14 / 2000$} & 1999.254 & 1999.052 \\
\hline & -0.015 & -0.010 \\
\hline \multirow{2}{*}{$02 / 28 / 2000$} & 1999.251 & 1999.053 \\
\hline & -0.018 & -0.009 \\
\hline \multirow{2}{*}{ 03/28/2000 } & 1999.247 & 1999.052 \\
\hline & -0.022 & -0.010 \\
\hline \multirow{2}{*}{$04 / 27 / 2000$} & 1999.242 & 1999.05 \\
\hline & -0.027 & -0.012 \\
\hline \multirow{2}{*}{$06 / 01 / 2000$} & 1999.241 & 1999.05 \\
\hline & -0.028 & -0.012 \\
\hline \multirow{2}{*}{$02 / 13 / 2002$} & 1999.216 & 1999.037 \\
\hline & -0.053 & -0.025 \\
\hline \multirow{2}{*}{$08 / 27 / 2002$} & 1999.214 & 1999.039 \\
\hline & -0.055 & -0.023 \\
\hline \multirow{2}{*}{ 03/06/2003 } & 1999.21 & 1999.036 \\
\hline & -0.059 & -0.026 \\
\hline \multirow{2}{*}{ 09/26/2003 } & 1999.207 & 1999.035 \\
\hline & -0.062 & -0.027 \\
\hline \multirow{2}{*}{ 03/10/2004 } & 1999.208 & 1999.036 \\
\hline & -0.061 & -0.026 \\
\hline \multirow{2}{*}{ 09/14/2004 } & 1999.209 & 1999.041 \\
\hline & -0.060 & -0.021 \\
\hline \multirow{2}{*}{ 03/22/2005 } & 1999.206 & 1999.037 \\
\hline & -0.063 & -0.025 \\
\hline \multirow{2}{*}{ 09/21/2005 } & 1999.206 & 1999.036 \\
\hline & -0.063 & -0.026 \\
\hline \multirow{2}{*}{$04 / 18 / 2006$} & 1999.203 & 1999.033 \\
\hline & -0.066 & -0.029 \\
\hline \multirow{2}{*}{ 09/19/2006 } & 1999.203 & 1999.034 \\
\hline & -0.066 & -0.029 \\
\hline \multirow{2}{*}{$02 / 22 / 2007$} & 1999.203 & 1999.031 \\
\hline & -0.066 & -0.031 \\
\hline
\end{tabular}

${ }^{a}$ Vertical datum: National Geodetic Vertical Datum of 1929 in meters

${ }^{\mathrm{b}}$ Horizontal datum: U.S. State Plane 1983; vertical datum: North American Vertical Datum of 1929

$\mathrm{N}=$ northing

$\mathrm{E}=$ easting 


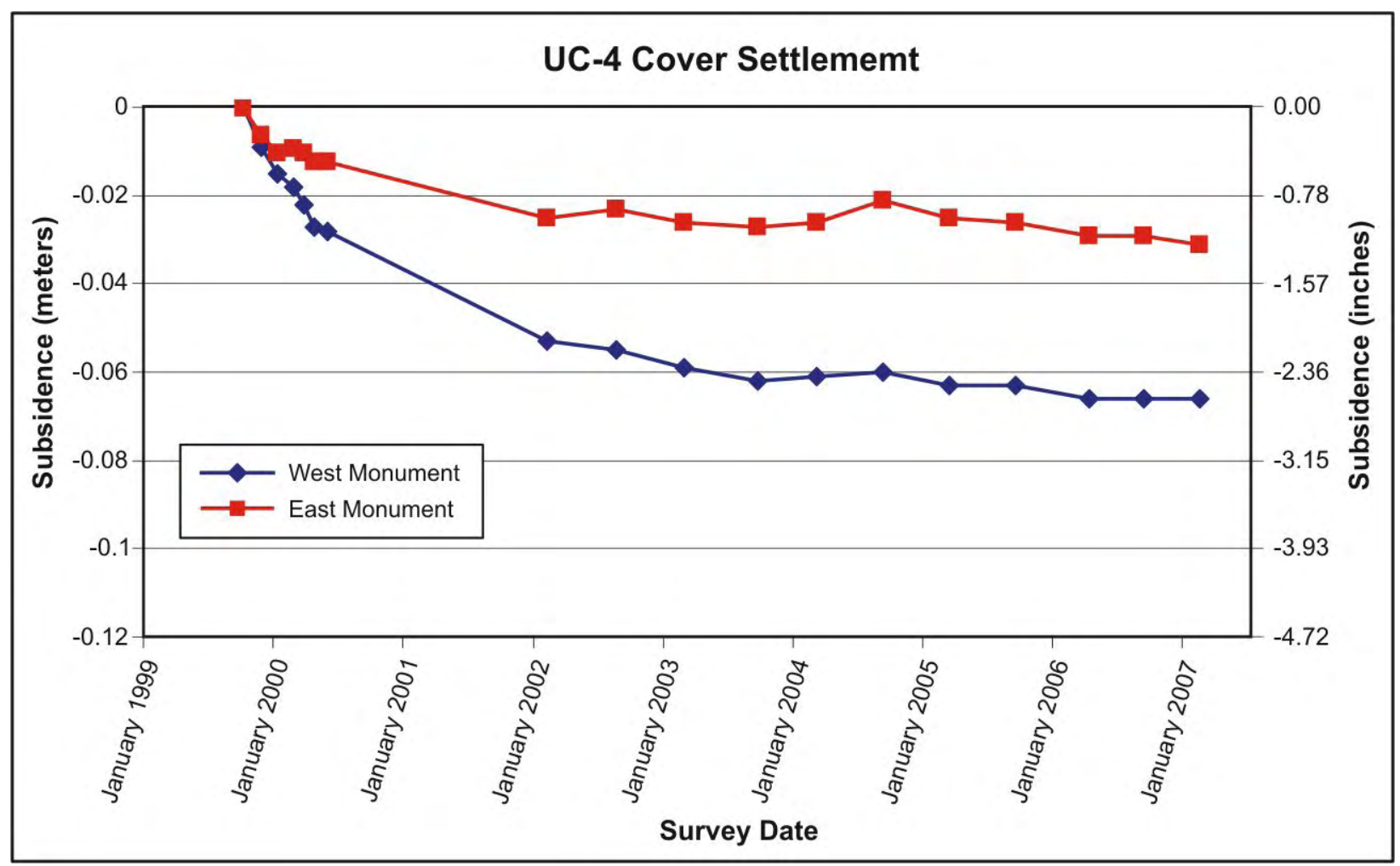

Figure 3-3. UC-4 Cover Settlement

\subsection{Vegetation Survey Results}

The vegetation survey was performed concurrently with the site inspection on May 15, 2007. The complete vegetation monitoring report is included in Appendix C. A summary of the vegetation survey is provided in this section.

The fenced UC-1 CMP cover and adjacent unfenced disturbed area were seeded in the autumn of 2000, and 5,000 transplants were planted on the soil cover in the spring of 2001.

Evapotranspiration by the vegetation reduces infiltration and percolation of storm water through the cover. The vegetation also helps reduce erosion of the cover by wind and water by reducing surface velocities.

Post-closure requirements for this site include periodic vegetation surveys to assess the establishment of a healthy and stable vascular plant cover and to monitor its effectiveness. A preliminary evaluation of the site was conducted in July 2001 to confirm germination, and subsequent surveys were conducted in October 2001, March 2002, September 2002, June 2003, June 2004, and May 2006 to evaluate the density, diversity, and overall condition of the vegetation. These evaluations demonstrated successful establishment of healthy plant communities and adequate resistance of the plants to cold weather. Seeded vegetation in the adjacent area outside the fence has not done as well as the vegetation on the cover because of animal grazing. 
The annual vegetation survey results indicated that approximately half of the Indian ricegrass plants observed within the fenced area appeared to be dormant or dead (i.e., they had not yet sprouted this year's green stems or leaves), and all of the rabbitbrush and fourwing saltbush plants had only begun to show evidence of new spring growth. Sagebrush plants did not show as much stress and appeared healthy. Average total plant cover on the CMP cover was estimated at 18 percent.

\subsection{Precipitation and Soil Moisture Monitoring Results}

Precipitation data are collected at the UC-1 CMP cover by a Campbell Scientific TE525 tipping bucket rain gauge with a CS705 precipitation adapter for snowfall measurements. The rain gauge data are collected and stored by the data logger until the daily TDR and precipitation data are transmitted via a satellite uplink to an earth station in Wallops Island, Virginia. The rain cage was inoperative from January through March 2007 but was placed back online in April 2007.

The data are automatically retrieved from the earth station daily through the Internet and imported into the System Operation and Analysis at Remote Sites (SOARS) system. The post-processing software used by SOARS automatically produces graphs and tables, and the data are automatically backed up daily.

The precipitation record for the UC-1 CMP cover is presented in Figure 3-4. Precipitation during 2007 was below average; the April through December rainfall total was 3.23 centimeters (1.27 inches). A summary of the results is provided in the following sections.

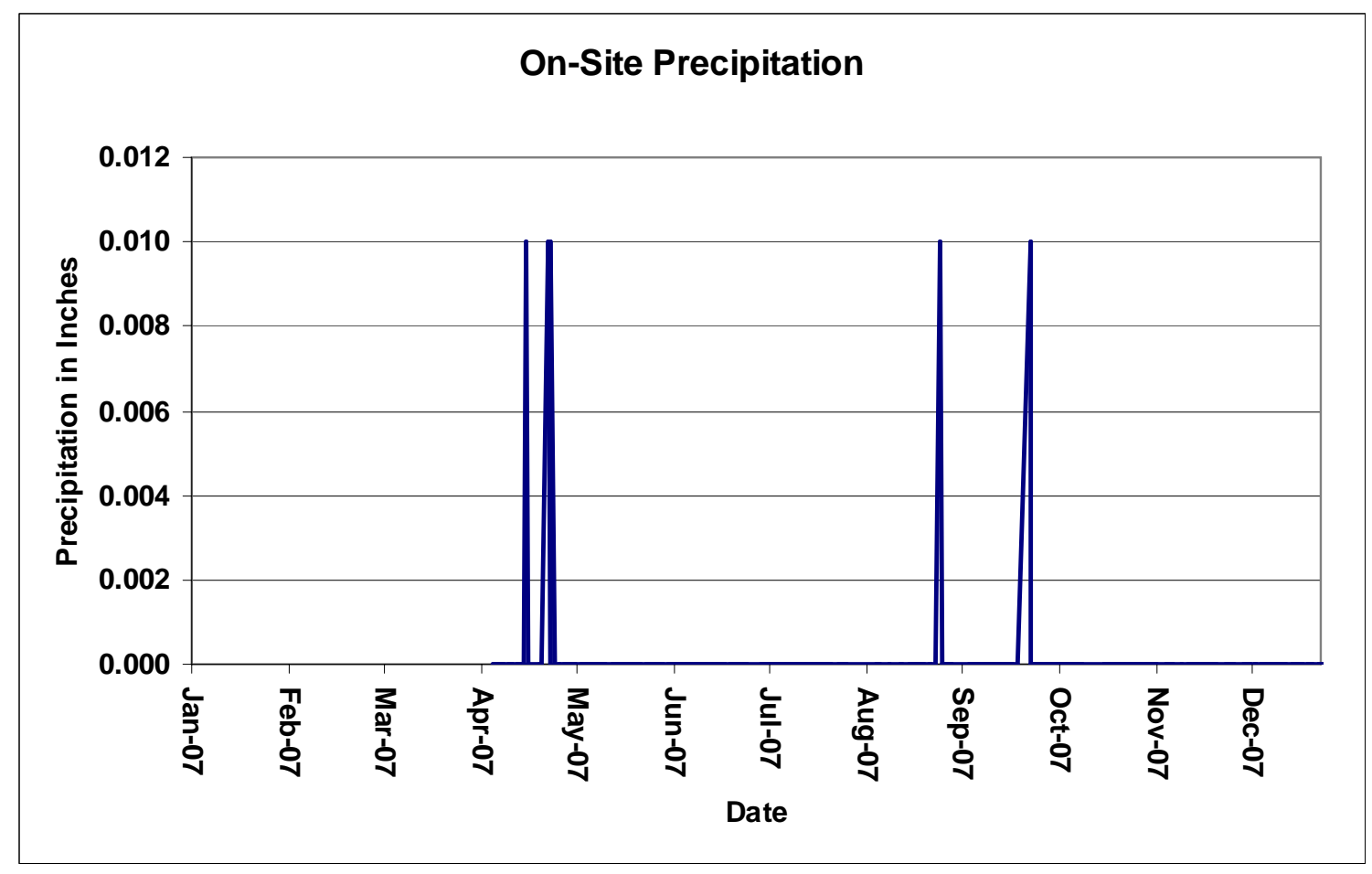

Figure 3-4. 2007 Precipitation Data 


\subsubsection{UC-1 Soil Moisture Results}

Graphs of the TDR-derived soil moisture content for 2007 are presented in Figure 3-5 through Figure 3-8. TDR data were not collected from December 2006 through early April 2007 because of system operations failure. The TDR system was brought back on line on April 7, 2007.

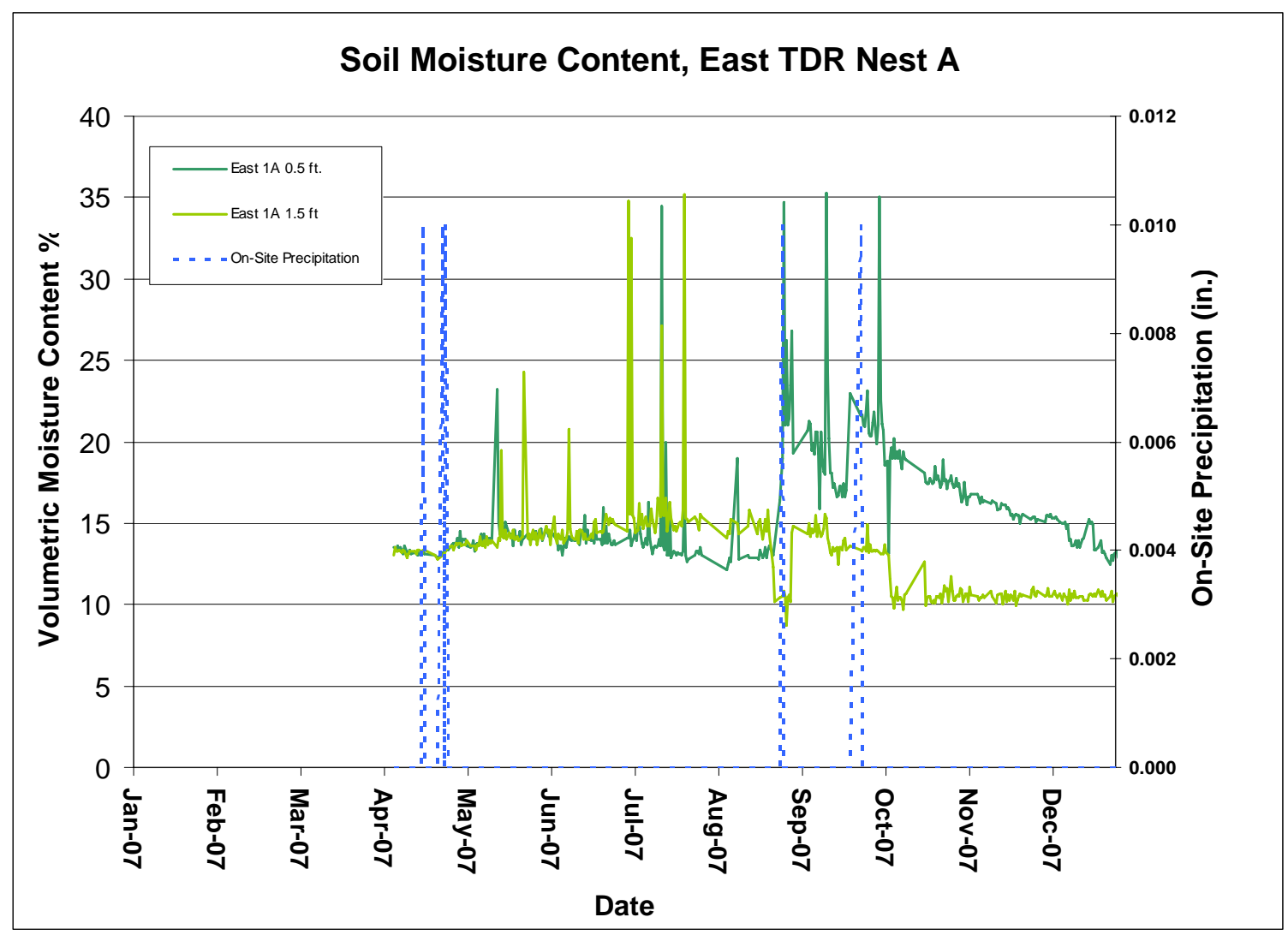

Figure 3-5. UC-1 Soil Moisture Content, East TDR Nest A 


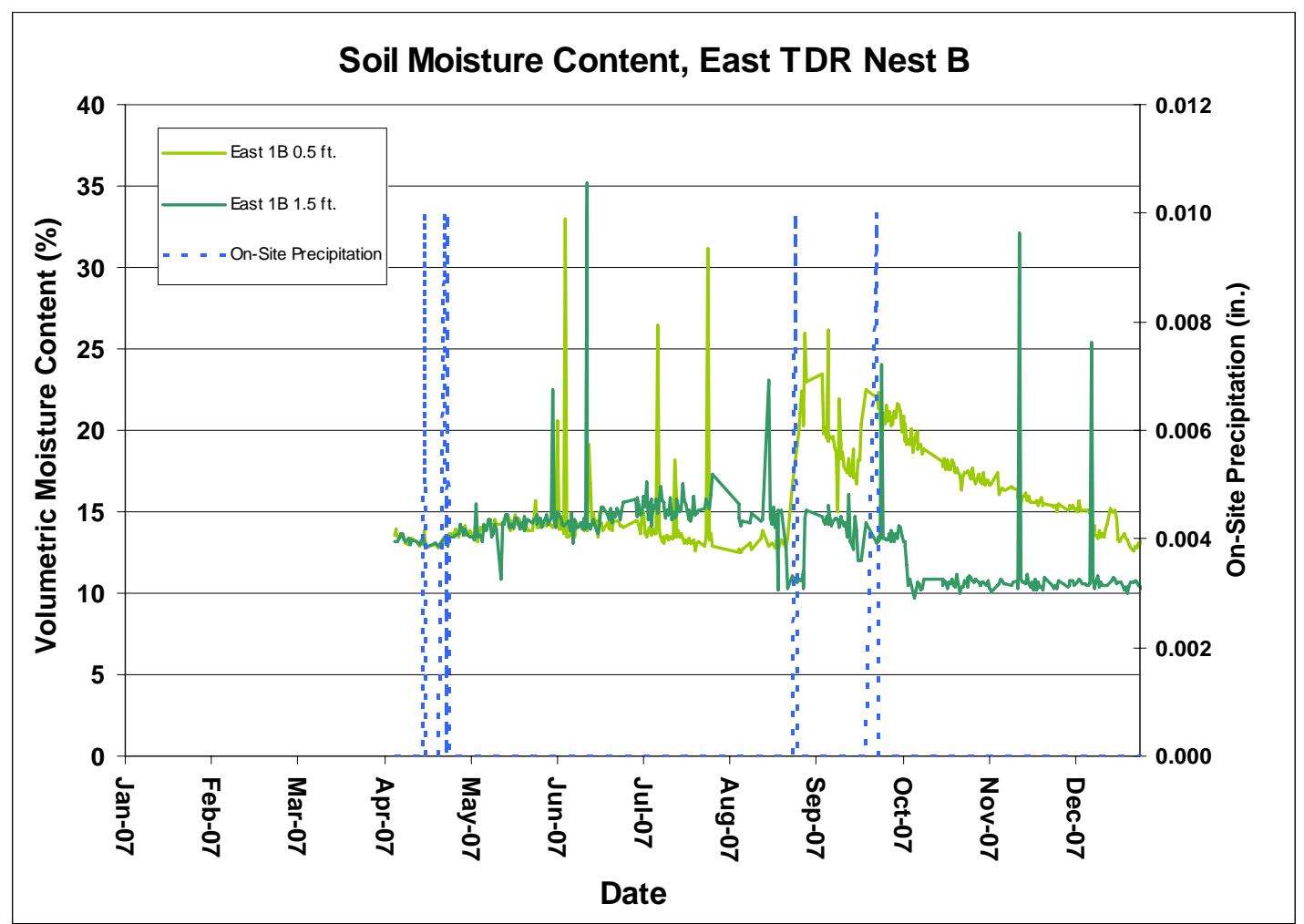

Figure 3-6. UC-1 Soil Moisture Content, East TDR Nest B

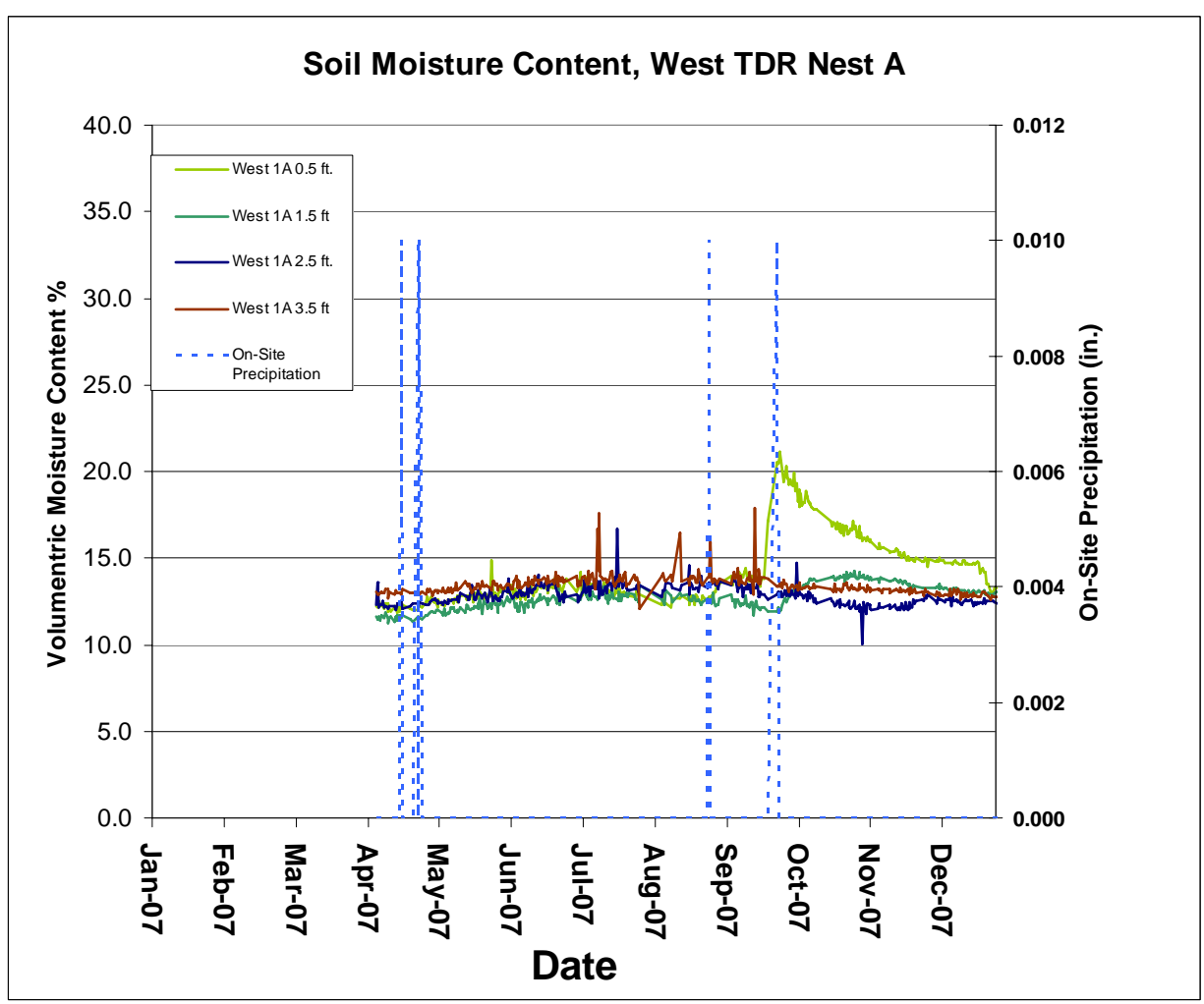

Figure 3-7. UC-1 Soil Moisture Content, West TDR Nest A 


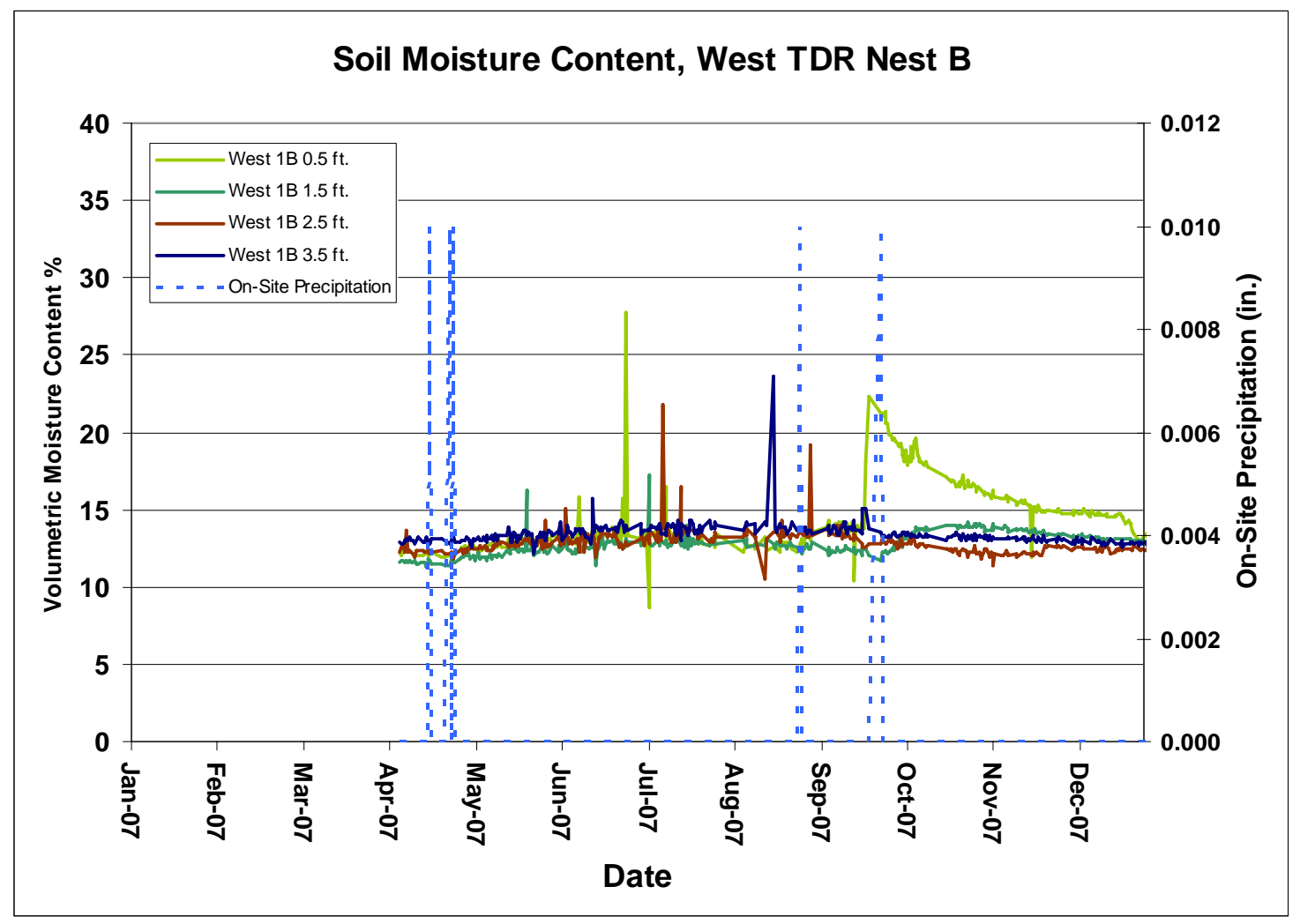

Figure 3-8. UC-1 Soil Moisture Content, West TDR Nest B

\section{UC-1 East TDR Nest}

TDR data obtained for the east nests for the 0.76- and 1.07-meter (2.5- and 3.5-ft, respectively) depths were entirely corrupted from an unknown cause. Previously, the long cable length created a problem in measuring the reflected signal from the TDR probes (NNSA/NV 2007). As a result, the data are very noisy and are missing entirely at the $0.76-\mathrm{m}$ and $1.07-\mathrm{m}(2.5-\mathrm{ft}$ and $3.5-\mathrm{ft}$, respectively) depths for both east nests. Inappropriate signal responses from the two TDR stations at depth in the east TDR nest make interpretation of the data difficult. Only the upper two depths are presented on the respective graphs, and from those profiles it is difficult to assess performance of the cover.

\section{UC-1 West TDR Nest}

Moisture content measurements indicate steady-state conditions throughout the year until mid-September, when moisture profiles of the near-surface depths increased. Overall, both nests present similar profiles and indicate the cover is performing as designed, with evapotranspiration effectively removing water from the cover. The moisture content at the two deeper profiles appears to be approaching steady state. 
This page intentionally left blank 


\subsection{Summary, Conclusions, and Recommendations}

\subsection{Summary}

The 2007 annual inspection of UC-1 CMP indicated the continued integrity of the cover unit. One new crack or fracture was observed on the UC-1 CMP cover during the December 2006 inspection. A crack located in the west portion of the cover showed evidence of lateral expansion. The crack was repaired with an application of bentonite fill in February 2007. No issues were identified with the fence or gate.

The May 2007 vegetation survey indicates that the UC-1 CMP revegetation is under droughtstressed conditions. The vegetation should continue to be monitored to document any changes in the plant community and identify conditions that could potentially require remedial action in order to maintain a viable vegetation cover on the site. It is suggested that future vegetation surveys be conducted once every 2 years or as needed to help monitor the health of the vegetation.

Precipitation during 2007 was below average; the April through December rainfall total was 3.23 centimeters (1.27 inches). Soil moisture content data show that the UC-1 cover is performing as designed, with saturated conditions at the cover-mud interface and evapotranspiration effectively removing water from the cover.

The UC-1 settling trend that has been seen since December 2000 continues to show a slight decrease in elevation during the current monitoring period, and most survey monuments showed only small changes from the 2006 to 2007 survey. The degree of settling in both the relocation trench and the CMP is within the predicted range and shows no unusual subsidence.

The inspections of UC-3 indicated that the sites are in excellent condition. All monuments and use-restriction signs are in good condition. No issues were identified, and no maintenance or repair activities are recommended at this time.

The last quarterly inspection done in December 2006 at UC-4 revealed that an erosion rill had formed along the east side of the Mud Pit C cover. This rill was repaired in February 2007. No concerns were identified with the monuments or gate.

Measurements at the UC-4 east monument indicated a slight decrease in elevation in the annual survey. The measurements in the elevation of the west monument stayed the same in both months of the 2006 surveys and remained the same in the 2007 survey. Subsidence at the west monument is still slightly greater than the predicted settling; the total subsidence was $6.6 \mathrm{~cm}$ (2.6 in.) since the baseline survey in October 1999. Settling of the monuments appears to have stabilized.

\subsection{Conclusions}

- $\quad$ No significant concerns were noted of the UC-1 CMP and UC-4 Mud Pit C covers during the annual inspection, and no further maintenance or repairs are recommended at this time.

- $\quad$ No significant concerns were noted on the subsidence surveys on UC-1 and UC-4. 
- $\quad$ The vegetation survey indicated that the vegetation on the UC-1 CMP and adjacent areas is drought-stressed.

- $\quad$ Soil moisture monitoring data indicate that the cover is performing as designed, and evapotranspiration is effectively removing water from the cover.

- $\quad$ The soil moisture monitoring compliance criteria cannot be established at this time because of below average rainfall during the past year.

\subsection{Recommendations}

- $\quad$ Continue site inspections annually as scheduled to observe the condition of the covers, fence, vegetation, signs, and monuments.

- $\quad$ Continue annual subsidence surveys on UC-1 and UC-4.

- $\quad$ Continue vegetation surveys once every 2 years or as needed to help monitor the health of the vegetation.

- $\quad$ Continue soil moisture data collection from only the west TDR nest.

- Meet with NDEP to discuss the closure plan with respect to historical site data collected, present site conditions, and future path forward. 


\subsection{References}

Barnes, W. 1968. Report of Exploration Progress, Central Nevada, Period August 1, 1967

December 31, 1967. U.S. Geological Survey Technical Letter, Central Nevada 3-2.

DOE/NV (U.S. Department of Energy, Nevada Operations Office), 2000. Corrective Action Plan for Corrective Action Unit 417: Central Nevada Test Area Surface, Nevada, DOE/NV-588, Las Vegas, Nevada.

FFACO (Federal Facility Agreement and Consent Order), 1996 (as amended). Agreed to by the State of Nevada, the U.S. Department of Energy, and the U.S. Department of Defense.

Healey, D. L. 1968. Gravity Survey of Northern Hot Creek Valley, Nye County, Nevada U.S. Geological Survey Technical Letter, Central Nevada-18.

NNSA/NV (U.S. Department of Energy, National Nuclear Security Administration Nevada Operations Office), 2001. Closure Report for Corrective Action Unit 417: Central Nevada Test Area Surface, Nevada, DOE/NV-743, Rev. 1, Las Vegas, Nevada.

NNSA/NV (U.S. Department of Energy, National Nuclear Security Administration Nevada Operations Office), 2007. Post-Closure Inspection and Monitoring Report for Corrective Action Unit 417: Central Nevada Test Area-Surface Hot Creek Valley, Nevada, DOE/NV/25946-168, Las Vegas, Nevada. 
This page intentionally left blank 


\section{Appendix A}

\section{Inspection Checklists,}

Field Notes, and Photographs 
This page intentionally left blank 


\section{Photograph Log}

\begin{tabular}{||c|c|l||}
\hline \hline Photograph & Date & Description \\
\hline \hline 1 & $02 / 22 / 2007$ & UC-1 View from south edge looking west \\
\hline 2 & $02 / 22 / 2007$ & UC-1 View from south edge looking northwest \\
\hline 3 & $02 / 22 / 2007$ & UC-1 View from south edge looking north \\
\hline 4 & $02 / 22 / 2007$ & UC-1 View from south edge looking northeast \\
\hline 5 & $02 / 22 / 2007$ & UC-1 View from south edge looking east \\
\hline 6 & $02 / 22 / 2007$ & UC-4 View from center looking west \\
\hline 7 & $02 / 22 / 2007$ & UC-4 View from center looking east \\
\hline 8 & $02 / 22 / 2007$ & UC-4 View from center looking southeast \\
\hline
\end{tabular}


This page intentionally left blank 


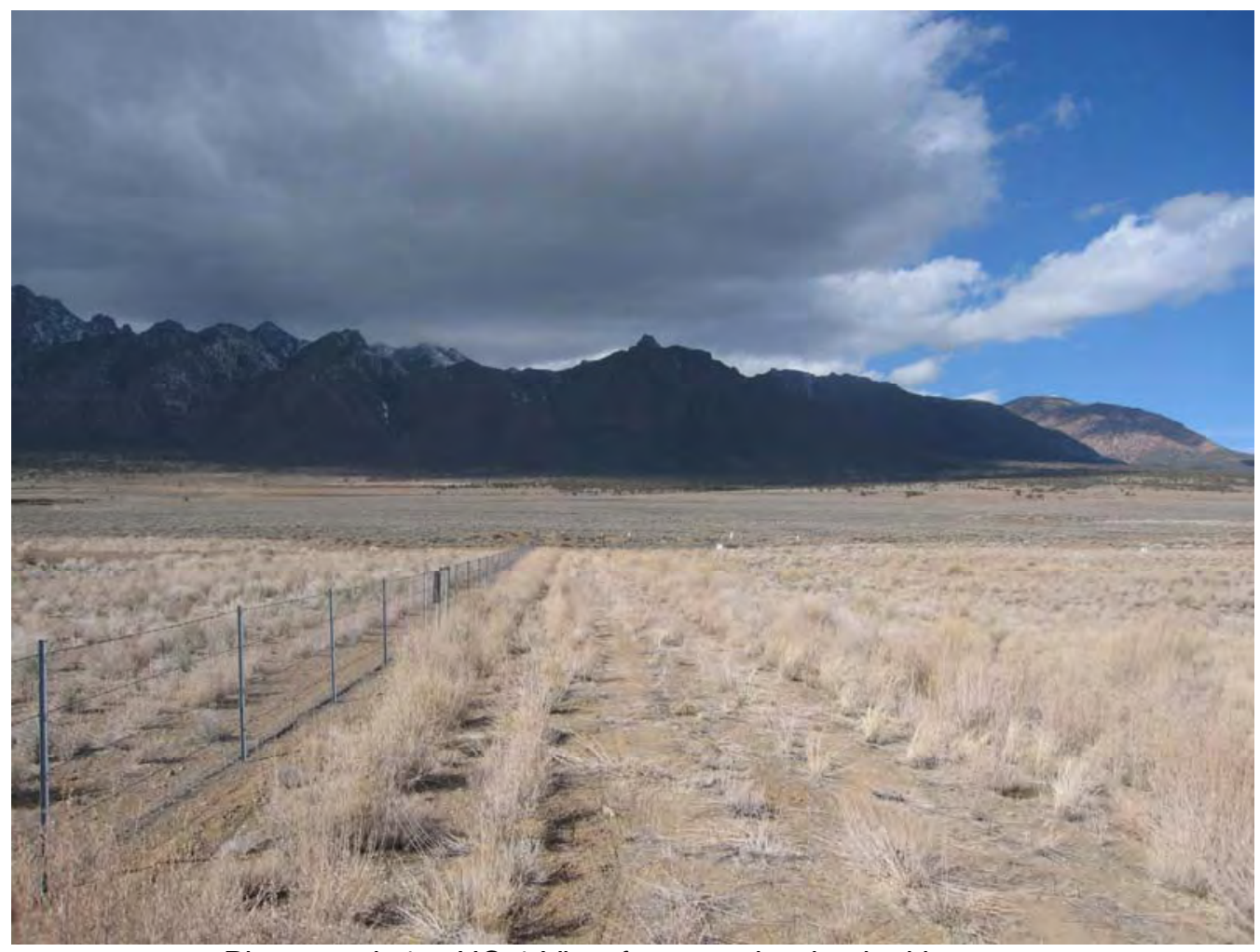

Photograph 1. UC-1 View from south edge looking west

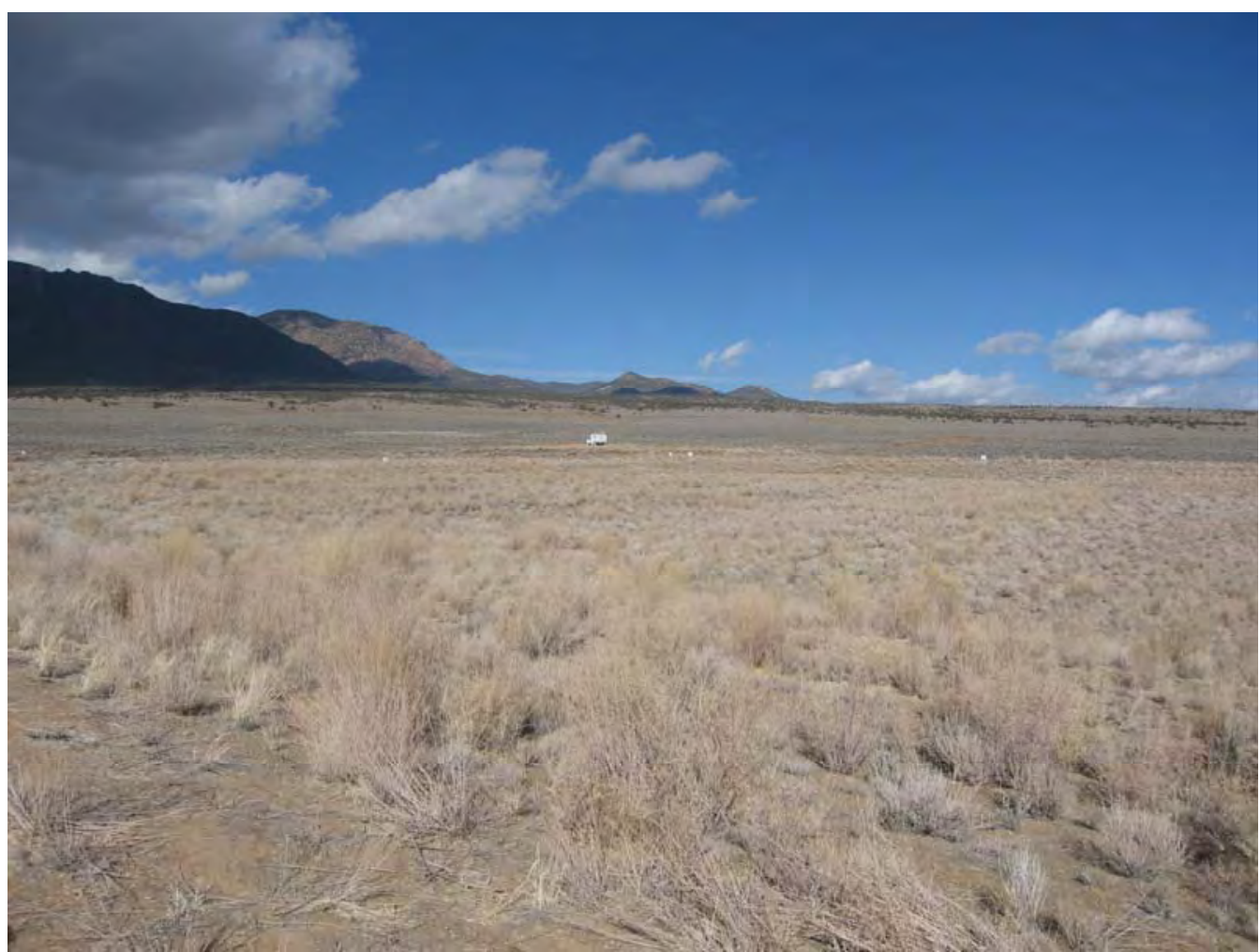

Photograph 2. UC-1 View from south edge looking northwest 


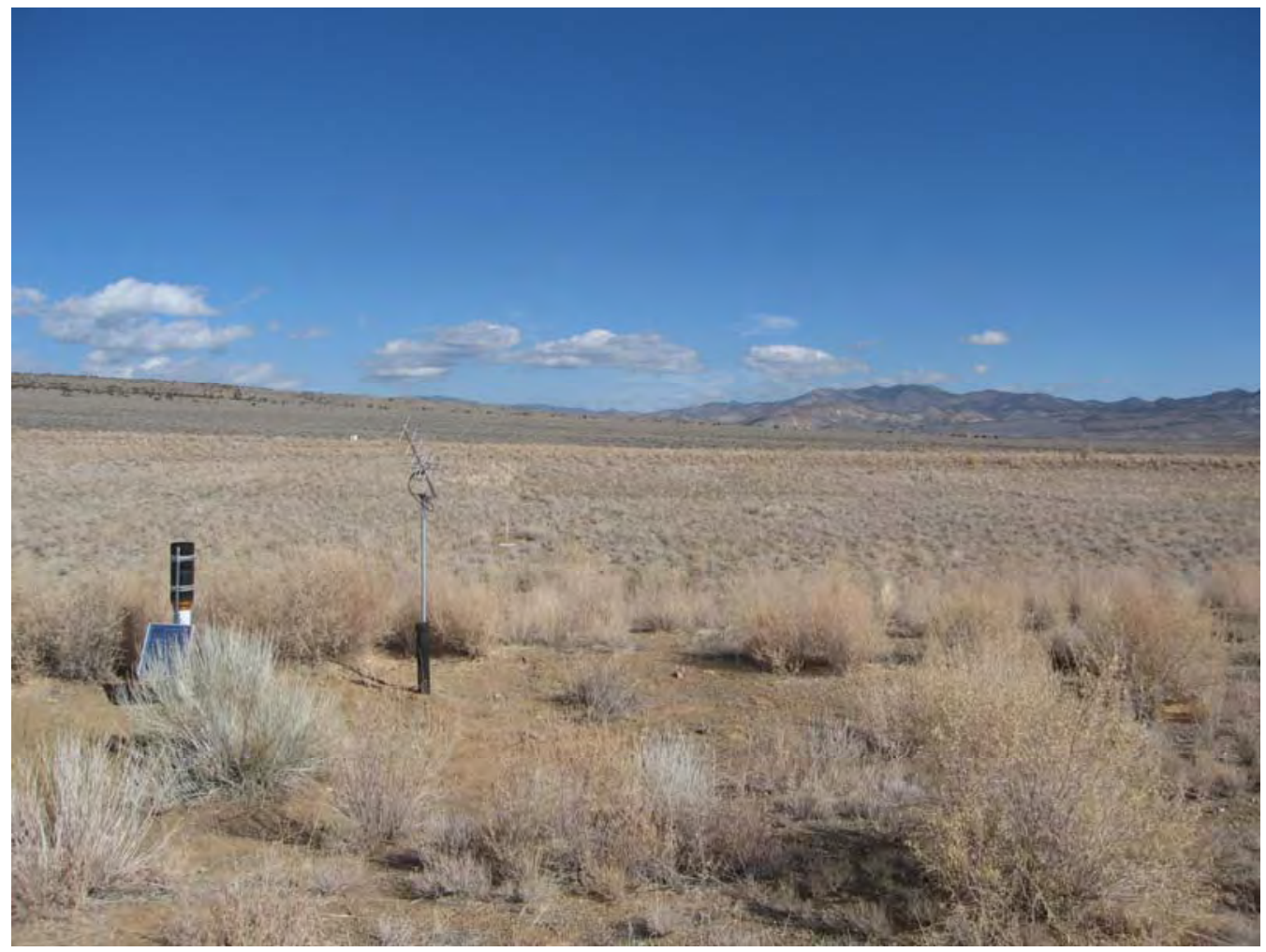

Photograph 3. UC-1 View from south edge looking north

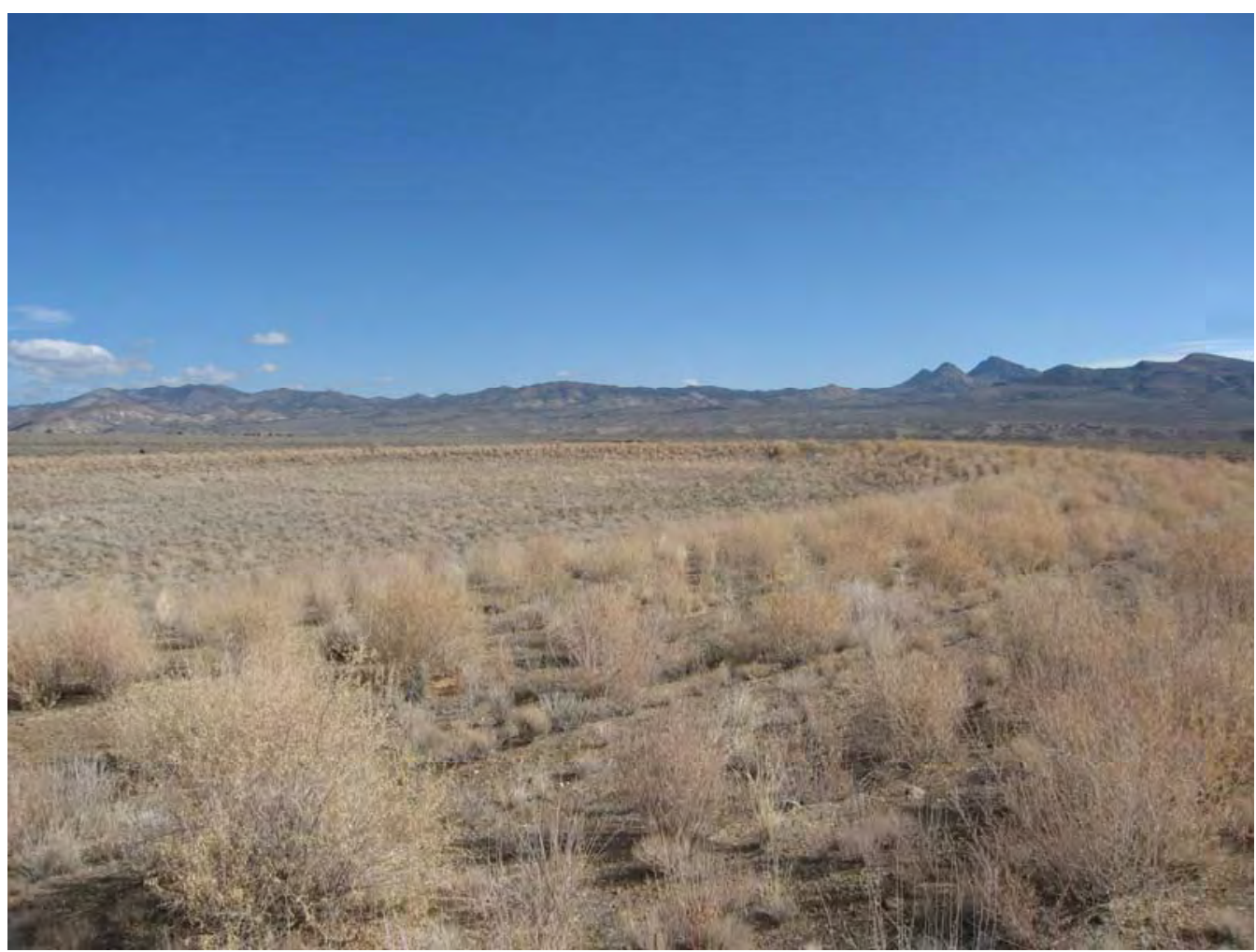

Photograph 4. UC-1 View from south edge looking northeast 


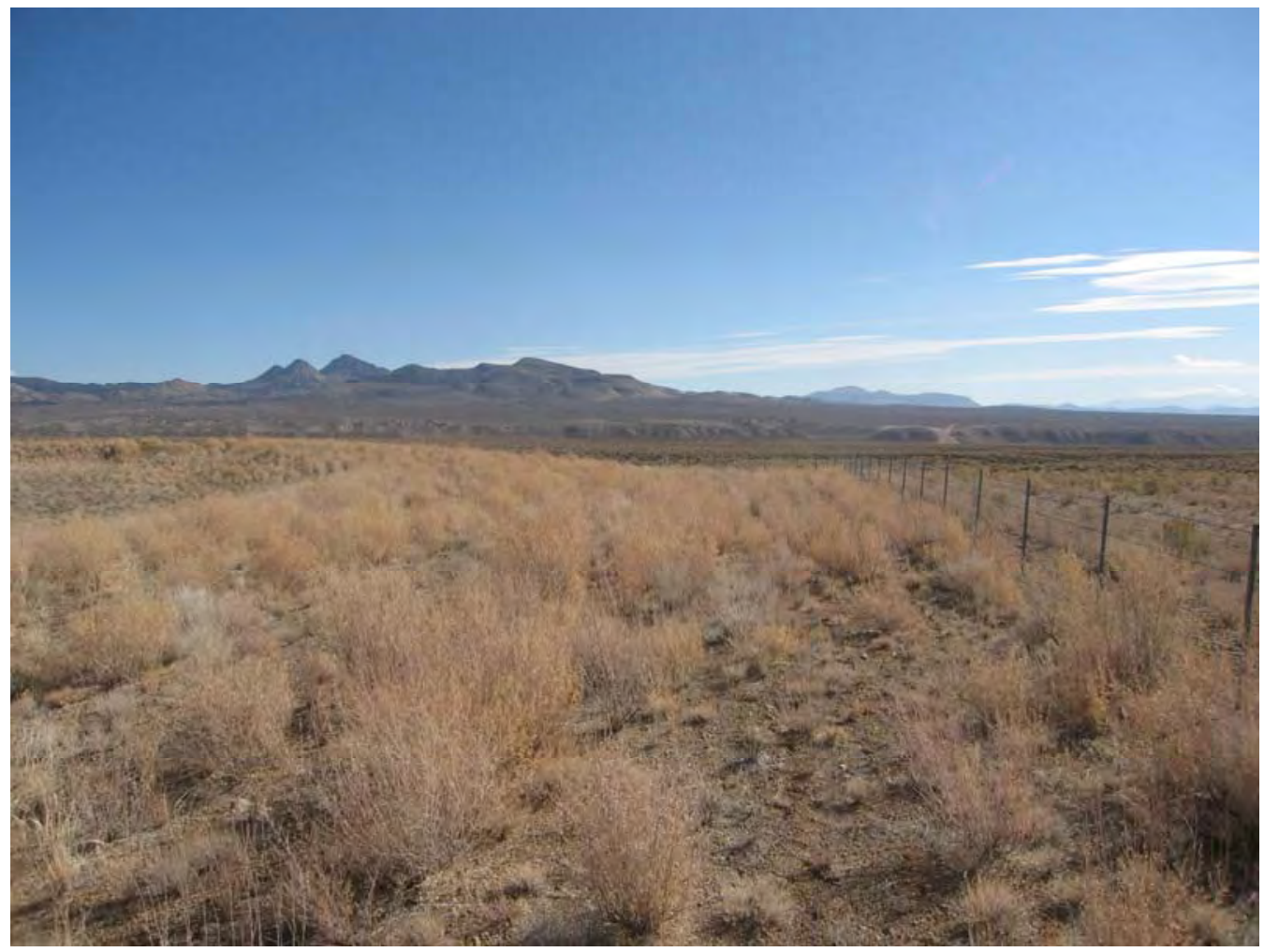

Photograph 5. UC-1 View from south edge looking east

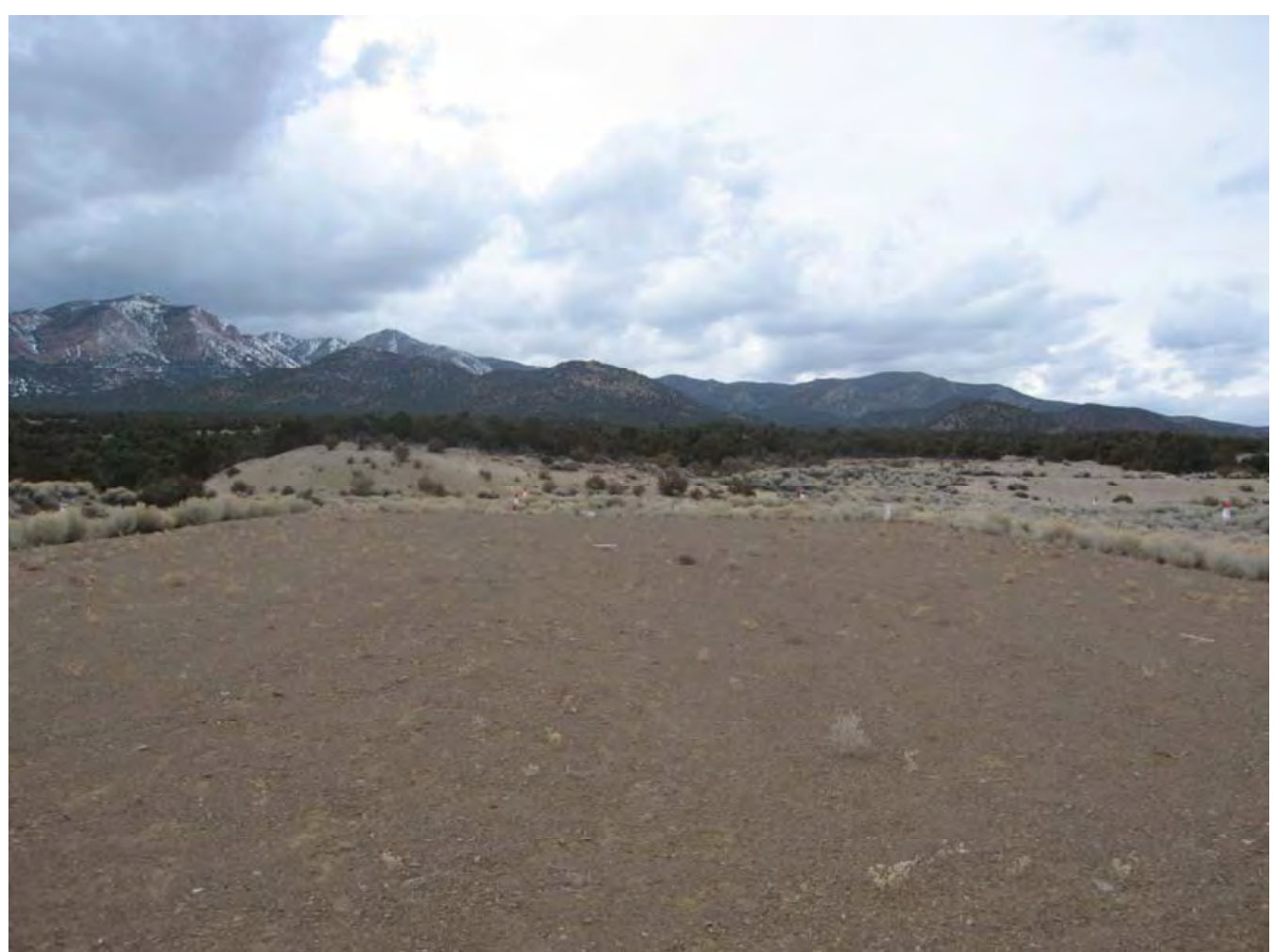

Photograph 6. UC-4 View from center looking west 


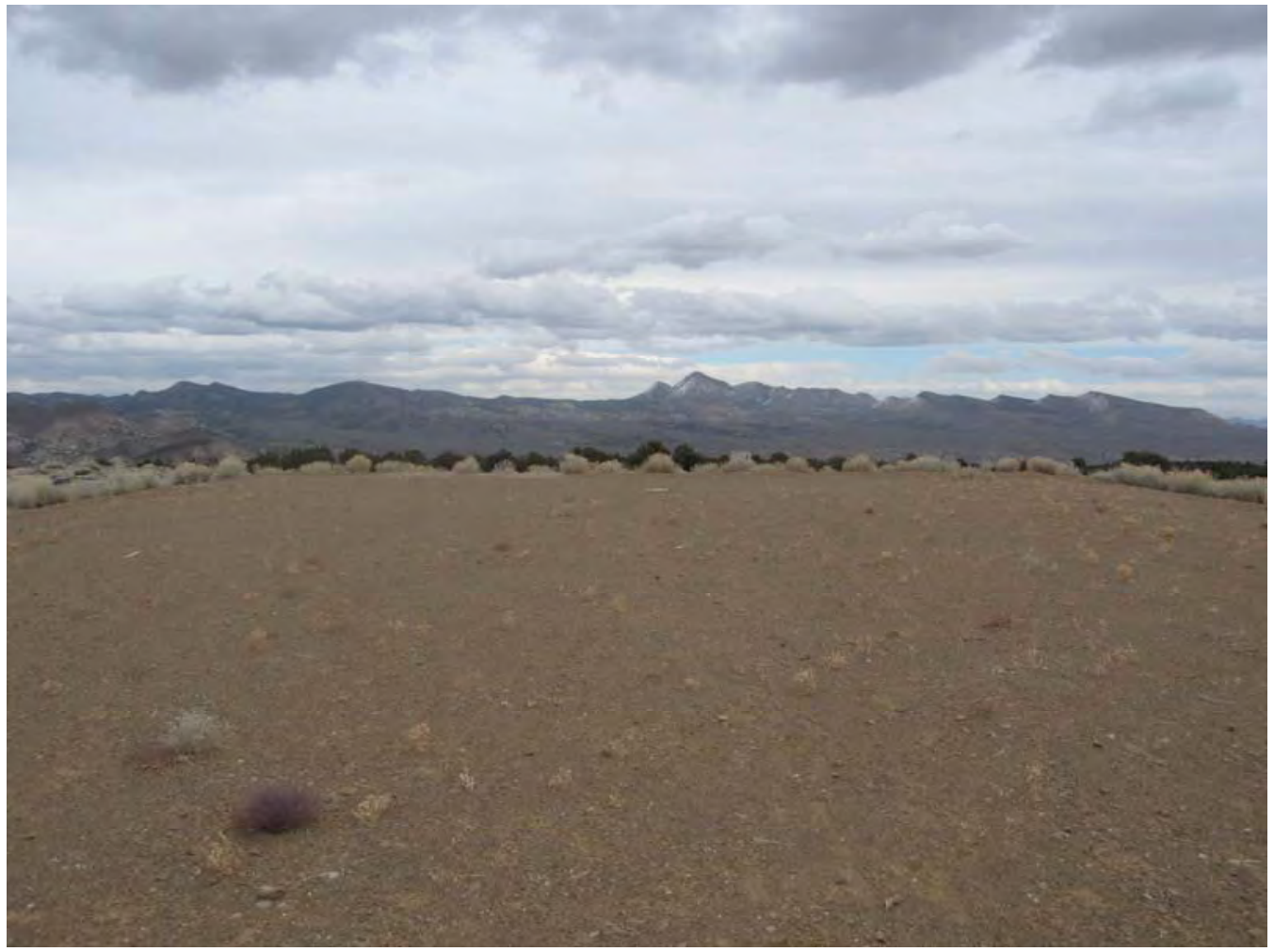

Photograph 7. UC-4 View from center looking east

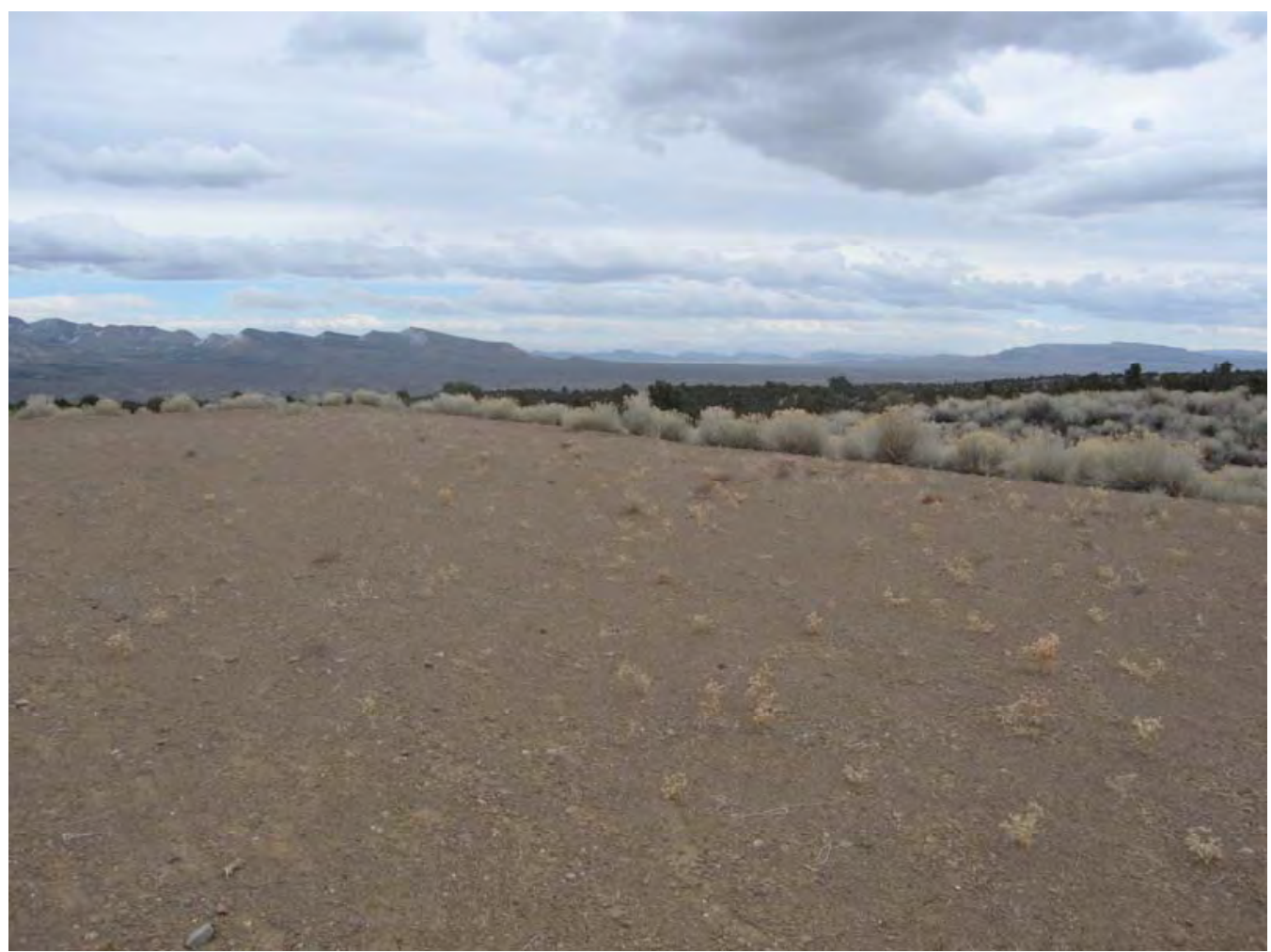

Photograph 8. UC-4 View from center looking southeast 
CAU 417: CNTA UC-1 CENTRAL MUD PIT COVER, POST-CLOSURE INSPECTION CHECKLIST

\begin{tabular}{|l|l|}
\hline \hline Date of Last Inspection: & Reason for Last Inspection: \\
\hline Responsible Agency: DOE LM & Project Manager: RICK HUTTON \\
\hline Inspection Date: MaY 15, 2007 & \\
\hline Inspector (name, title, organization): PAML S.DARR, Techulcal Lead, STOCLER \\
\hline Assistant Inspector (name, title, organization):
\end{tabular}

\section{A. GENERAL INSTRUCTIONS}

1. All checklist items must be completed and detailed comments made to document the results of the site inspection. The completed checklist is part of the field record of the inspection. Additional pages should be used as necessary to ensure that a complete record is made. Attach the additional pages and number all pages upon completion of the inspection.

3. Any checklist line item marked by an inspector in a SHADED BOX, must be fully explained or an appropriate reference to previous reports provided. The purpose of this requirement is to provide a written explanation of inspector observations and the inspector's rationale for conclusions and recommendations. Explanations are to be placed on additional attachments and cross-referenced appropriately. Explanations, in addition to narrative, will take the form of sketches, measurements, annotated site maps.

4. The site inspection is a walking inspection of the entire site including the perimeter and sufficient transects to be able to inspect the entire surface and all features specifically described in this checklist.

5. A standard set of color $35 \mathrm{~mm}$ photographs (or equivalent) is required. In addition, all anomalous features or new features (such as changes in adjacent area land use) are to be photographed. A photo log entry will be made for each photograph taken.

6. This unit will be inspected biannually with formal reporting to the Nevada Division of Environmental Protection to be done annually. The annual report will include an executive summary, this inspection checklist with field notes and photo log attached, and recommendations and conclusions.

B. PREPARATION (To be completed prior to site visit)

1. Site as-built plans and site base map reviewed.

2. Previous inspection reports reviewed.

a. Were anomalies or trends detected on previous inspections?

b. Was maintenance performed?

3. Site maintenance and repair records reviewed.

a. Has site repair resulted in a change from as-built conditions?

b. Are revised as-builts available that reflect repair changes?

C. SITE INSPECTION (To be completed during inspection)

1. Adjacent off-site features within watershed areas.

a. Have there been any changes in use of adjacent area?

b. Are there any new roads or trails?

c. Has there been a change in the position of nearby washes?

d. Has there been lateral excursion or erosion/deposition of nearby washes?

e. Are there new drainage channels?

f. Change in surrounding vegetation?

\begin{tabular}{|l|l|l|}
\hline YES & NO & EXPLANATION \\
\hline$\swarrow$ & & \\
\hline$\swarrow$ & & \\
\hline & $\swarrow$ & \\
\hline & $\swarrow$ & \\
\hline$\swarrow$ & & \\
\hline & $\swarrow$ & \\
\hline & & $N / A$ \\
\hline YES & NO & EXPLANATION \\
\hline
\end{tabular}

Security fence, signs.

a. Displacement of fences, site markers, boundary markers, or monuments?

b. Have any signs been damaged or removed? (Number of signs replaced: $\varnothing$ )

c. Were gates locked?

\begin{tabular}{|l|l|l|}
\hline & $\checkmark$ & \\
\hline & $\checkmark$ & \\
\hline & $\checkmark$ & \\
\hline & $\checkmark$ & \\
\hline & $\checkmark$ & \\
\hline & $\checkmark$ & \\
\hline
\end{tabular}

\begin{tabular}{|l|l|l||}
\hline & $\checkmark$ & \\
\hline & $\swarrow$ & \\
\hline$\checkmark$ & & \\
\hline
\end{tabular}




\section{CAU 417: CNTA UC-1 CENTRAL MUD PIT COVER, POST-CLOSURE MONITORING CHECKLIST}

3. Waste Unit cover.

a. Is there evidence of settling?

b. Is there cracking?

c. Is there evidence of erosion around the cap (wind or water)?

d. Is there evidence of animal burrowing?

e. Have the site markers been disturbed by man or natura processes?

f. Do natural processes threaten to integrity of any cover or site marker?

g. Other?

\begin{tabular}{|l|l|l|}
\hline \multicolumn{1}{|l}{ YES } & NO & \multicolumn{2}{l|}{ EXPLANATION } \\
\hline & $\swarrow$ & \\
\hline & $\cdot$ & Several cracks historically \\
\hline & $\swarrow$ & \\
\hline & $\swarrow$ & \\
\hline & $\swarrow$ & \\
\hline & $\swarrow$ & \\
\hline & & N/A \\
\hline
\end{tabular}

4. Vegetative cover.

a. Is perimeter fence or mesh fencing damaged?

b. Is there evidence of horses or rabbits on site?

c. Is organic mulch and/or plants adequate to prevent erosion?

d. Are weedy annual plants present? If yes, are they a problem?

e. Are seeded plant species found on site?

f. Is there evidence of plant mortality?

5. Photo Documentation

a. Has a photo log been prepared?

c. Number of photos exposed 5

\begin{tabular}{|l|l|l|}
\hline & $\checkmark$ & \\
\hline & $\checkmark$ & \\
\hline & $\checkmark$ & Vegetation is thinning \\
\hline$\checkmark$ & & Donot appear to be probler \\
\hline$\checkmark$ & & \\
\hline$\checkmark$ & & Drought conditious exist \\
\hline
\end{tabular}

FIELD CONCLUSIONS

1. Is there an imminent hazard to the integrity of the unit? (Immediate report required)

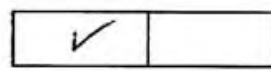

5

Person/Agency to whom report made:

2. Are more frequent inspections required?

3. Are existing maintenance/repair actions satisfactory?

4. Is other maintenance/repair necessary?

5. Is current status/condition of vegetative cover satisfactory? 6. Rationale for field conclusions: Overall integrity of cell is good. Plant thinaing due
to inadequate rainfall.

\section{E. CERTIFICATION}

I have conducted an inspection of the UC-1 Cental Mud Pit Cover, CAU 417, at the Central Nevada Test Area in accordance with the PostClosure Monitoring Plan (see Closure Report) as recorded on this checklist, attached sheets, field notes, photo logs, and photographs.

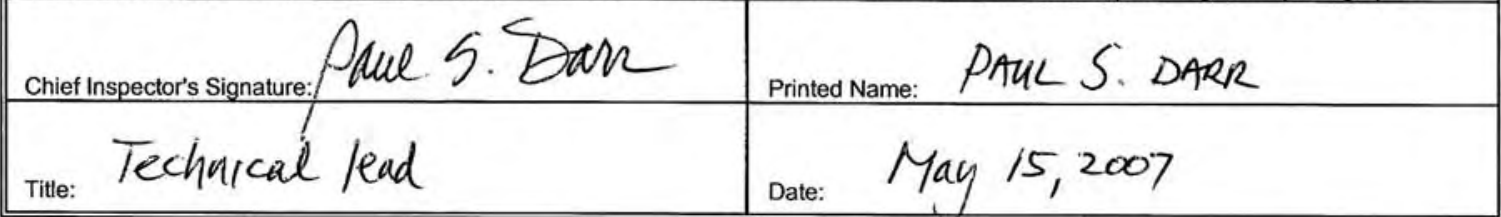




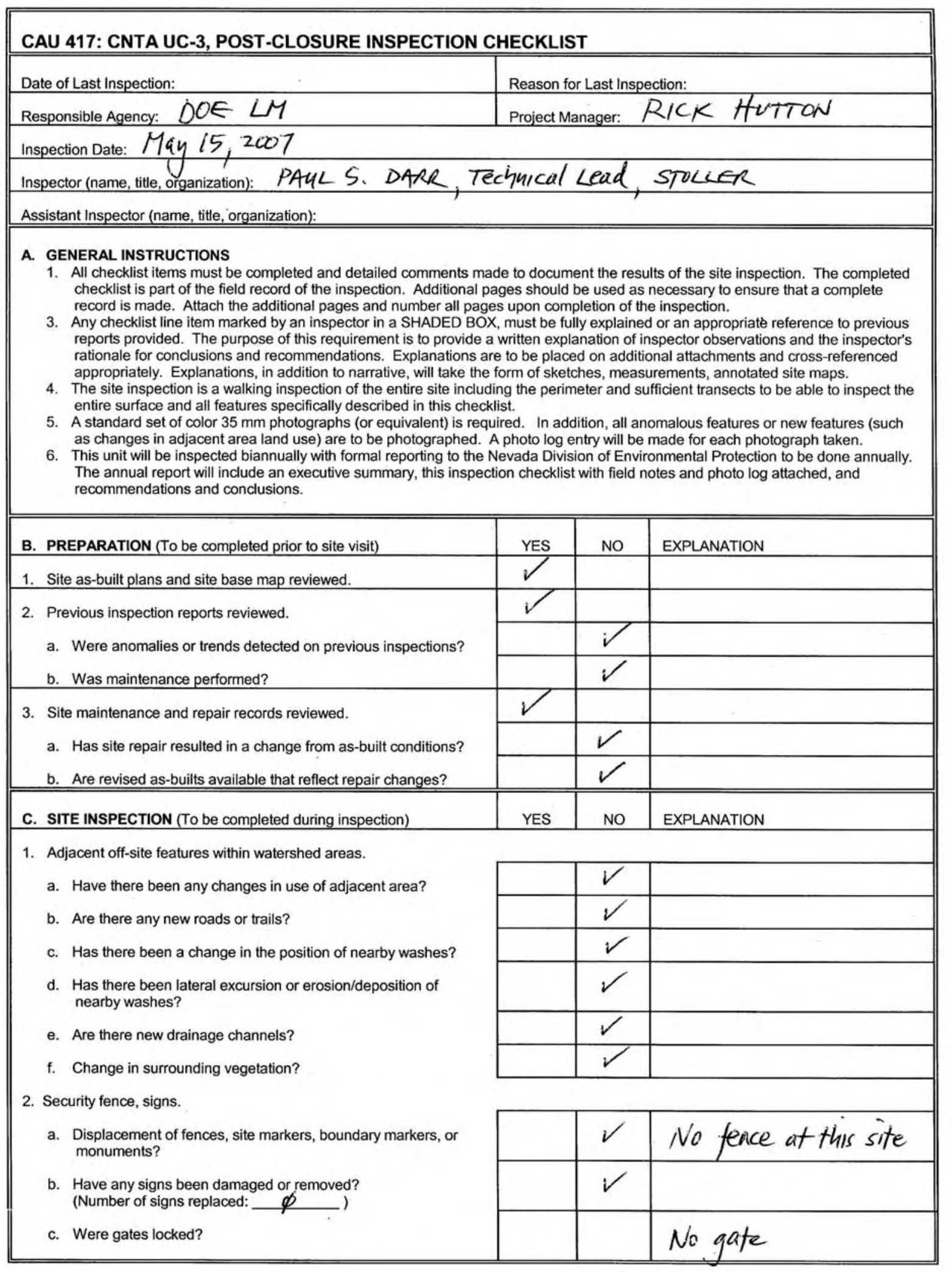




\begin{tabular}{|c|c|c|}
\hline \multicolumn{3}{|l|}{ D. FIELD CONCLUSIONS } \\
\hline $\begin{array}{l}\text { 1. Is there an imminent hazard to the integrity of the unit? } \\
\text { (Immediate report required) }\end{array}$ & & $\checkmark$ \\
\hline \multicolumn{3}{|l|}{ Person/Agency to whom report made: } \\
\hline 2. Are more frequent inspections required? & & $\checkmark$ \\
\hline 3. Are existing maintenance/repair actions satisfactory? & $\checkmark$ & \\
\hline 4. Is other maintenance/repair necessary? & & $\sqrt{ }$ \\
\hline \multicolumn{3}{|c|}{\begin{tabular}{|l|l} 
5. Is current status/condition of unit satisfactory? & \\
\end{tabular}} \\
\hline \multicolumn{3}{|c|}{ 6. Rationale for field conclusions: Site is in good condition. } \\
\hline \multicolumn{3}{|l|}{ E. CERTIFICATION } \\
\hline \multicolumn{3}{|c|}{$\begin{array}{l}\text { I have conducted an inspection of UC-3, CAU 417, at the Central Nevada Test Area in accordance with the Post-Closure Monitoring Plan } \\
\text { (see Closure Report) as recorded on this checklist, attached sheets, field notes, photo logs, and photographs. }\end{array}$} \\
\hline Chief Inspector's Signature: Arue is. Eam & Printed Name: & PAML S. DARR \\
\hline Title: Techuccal Lead & Date: & lay 15,2007 \\
\hline
\end{tabular}




\begin{tabular}{|l|l|}
\hline \hline \multicolumn{2}{||l}{ CAU 417: CNTA UC-4 MUD PIT C COVER, POST-CLOSURE INSPECTION CHECKLIST } \\
\hline \hline Date of Last Inspection: & Reason for Last Inspection: \\
\hline Responsible Agency: DOE LM & Project Manager: RICK ITUTTON \\
\hline Inspection Date: MaY 15, 2007 & \\
\hline Inspector (name, title, organization): PAUL S. DARR, Techuical LCad, STOULR \\
\hline Assistant Inspector (name, title, organization):
\end{tabular}

\section{A. GENERAL INSTRUCTIONS}

1. All checklist items must be completed and detailed comments made to document the results of the site inspection. The completed checklist is part of the field record of the inspection. Additional pages should be used as necessary to ensure that a complete record is made. Attach the additional pages and number all pages upon completion of the inspection.

3. Any checklist line item marked by an inspector in a SHADED BOX, must be fully explained or an appropriate reference to previous reports provided. The purpose of this requirement is to provide a written explanation of inspector observations and the inspector's rationale for conclusions and recommendations. Explanations are to be placed on additional attachments and cross-referenced appropriately. Explanations, in addition to narrative, will take the form of sketches, measurements, annotated site maps.

4. The site inspection is a walking inspection of the entire site including the perimeter and sufficient transects to be able to inspect the entire surface and all features specifically described in this checklist.

5. A standard set of color $35 \mathrm{~mm}$ photographs (or equivalent) is required. In addition, all anomalous features or new features (such as changes in adjacent area land use) are to be photographed. A photo log entry will be made for each photograph taken.

6. This unit will be inspected biannually with formal reporting to the Nevada Division of Environmental Protection to be done annually, The annual report will include an executive summary, this inspection checklist with field notes and photo log attached, and recommendations and conclusions.

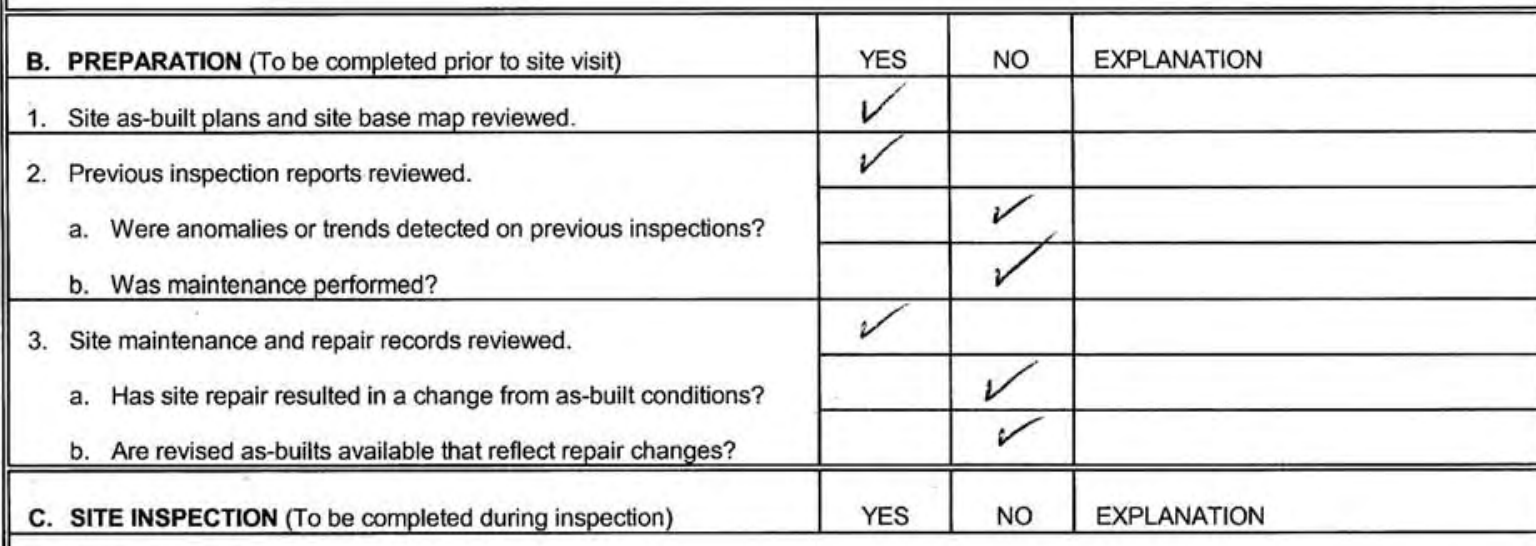

1. Adjacent off-site features within watershed areas.

a. Have there been any changes in use of adjacent area?

b. Are there any new roads or trails?

c. Has there been a change in the position of nearby washes?

d. Has there been lateral excursion or erosion/deposition of nearby washes?

e. Are there new drainage channels?

f. Change in surrounding vegetation?

\begin{tabular}{|l|l|l|}
\hline & $\checkmark$ & \\
\hline & $\checkmark$ & \\
\hline & $\checkmark$ & \\
\hline & $\checkmark$ & \\
\hline & $\checkmark$ & \\
\hline & $\checkmark$ & \\
\hline
\end{tabular}

2. Security fence, signs.

a. Displacement of fences, site markers, boundary markers, or monuments?

b. Have any signs been damaged or removed? (Number of signs replaced: $\phi^{\text {(emoved? }}$

c. Were gates locked?

\begin{tabular}{|l|l|l|}
\hline & $\checkmark$ & \\
\hline & $\checkmark$ & \\
\hline$\checkmark$ & & \\
\hline
\end{tabular}




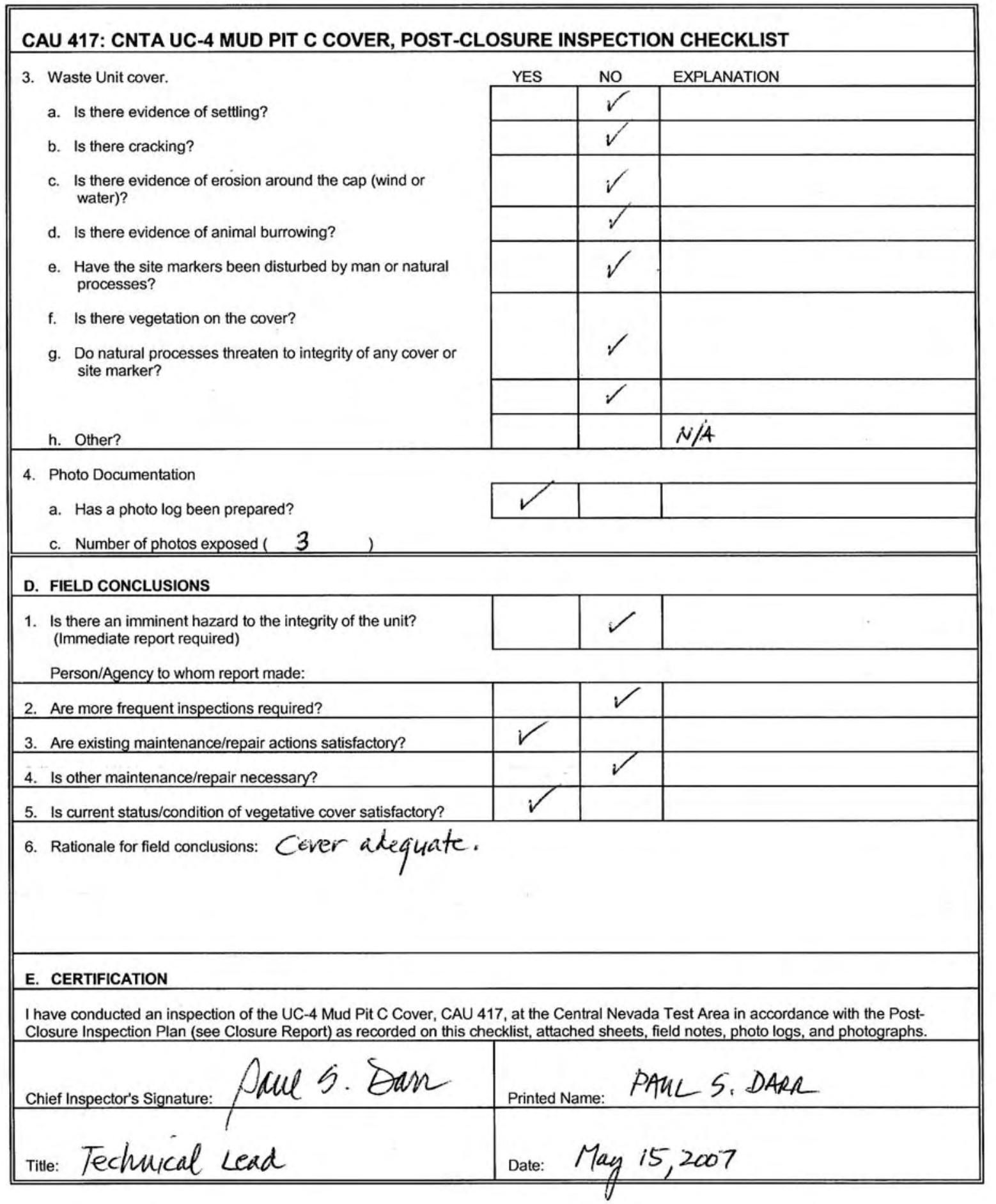




\section{Appendix B}

Historical Moisture Monitoring Data 
This page intentionally left blank 


\section{B.1 Historical Precipitation Data}

Precipitation data have been collected at the UC-1 CMP cover by a Campbell Scientific TE525 tipping bucket rain gauge fitted with a CS705 precipitation adapter for snowfall measurements. The rain gauge data are collected and stored by the data logger until the daily TDR and precipitation data are transmitted via a satellite uplink to an earth station in Wallops Island, Virginia. The data are retrieved from the earth station periodically for processing, analysis, and archive. Beginning in late 2005, the on-site rain gauge began experiencing operational difficulties. The nearest meteorological station is approximately 25 miles south of the site. Rainfall measurements from the Pancake Meteorological Station have been substituted for the on-site station.

The historical precipitation record for the UC-1 CMP cover is presented in Figure B-1.

\section{B.2 Historical Soil Moisture Monitoring Results}

\section{B.2.1 Five-Year Results}

Graphs of the TDR-derived soil moisture content for the past 5 years, combined with the precipitation data from the rain gauge, are presented in Figure B-2 through Figure B-5. Each TDR location (east and west) is composed of two separate stacks of four TDR probes, designated

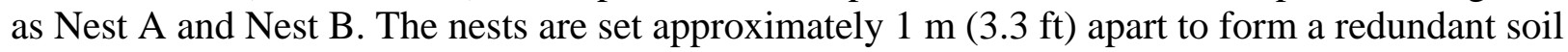
moisture measurement profile. The east nest is located near the centerline of the cover where the mud thickness is greatest, while the west nest is located farther up the flank of the CMP cover where the underlying mud layer is thinner. The east nest was placed to monitor the area where maximum soil water content would be expected, that is, near the cover drainage channel and over an area of maximum mud thickness where the weight of the cover would force the most excess water from the underlying drilling mud. The west nest was placed in an area more representative of the cover in general.

The soil moisture graphs, Figure B-2 through Figure B-5, show several responses: the initial conditions, wetting events, infiltration, and the return to steady-state conditions under both barren and vegetated conditions. The initial conditions at the beginning of the data collection reflect the disturbed soil's intrinsic moisture conditions. The installation of the TDR probes is described in detail in the CAU 417 Closure Report (NNSA/NV 2001). The trenching and compaction of each of the soil lifts disturbed the soil profile and resulted in a nonuniform vertical soil moisture profile. Consequently, some depths appeared wetter than others and will remain so until the system reaches equilibrium. Vegetation is not present directly over the TDR nests, only surrounding them. Therefore, some excess infiltration and lower than normal evapotranspiration can be expected until the vegetation over the TDR nests become established. 


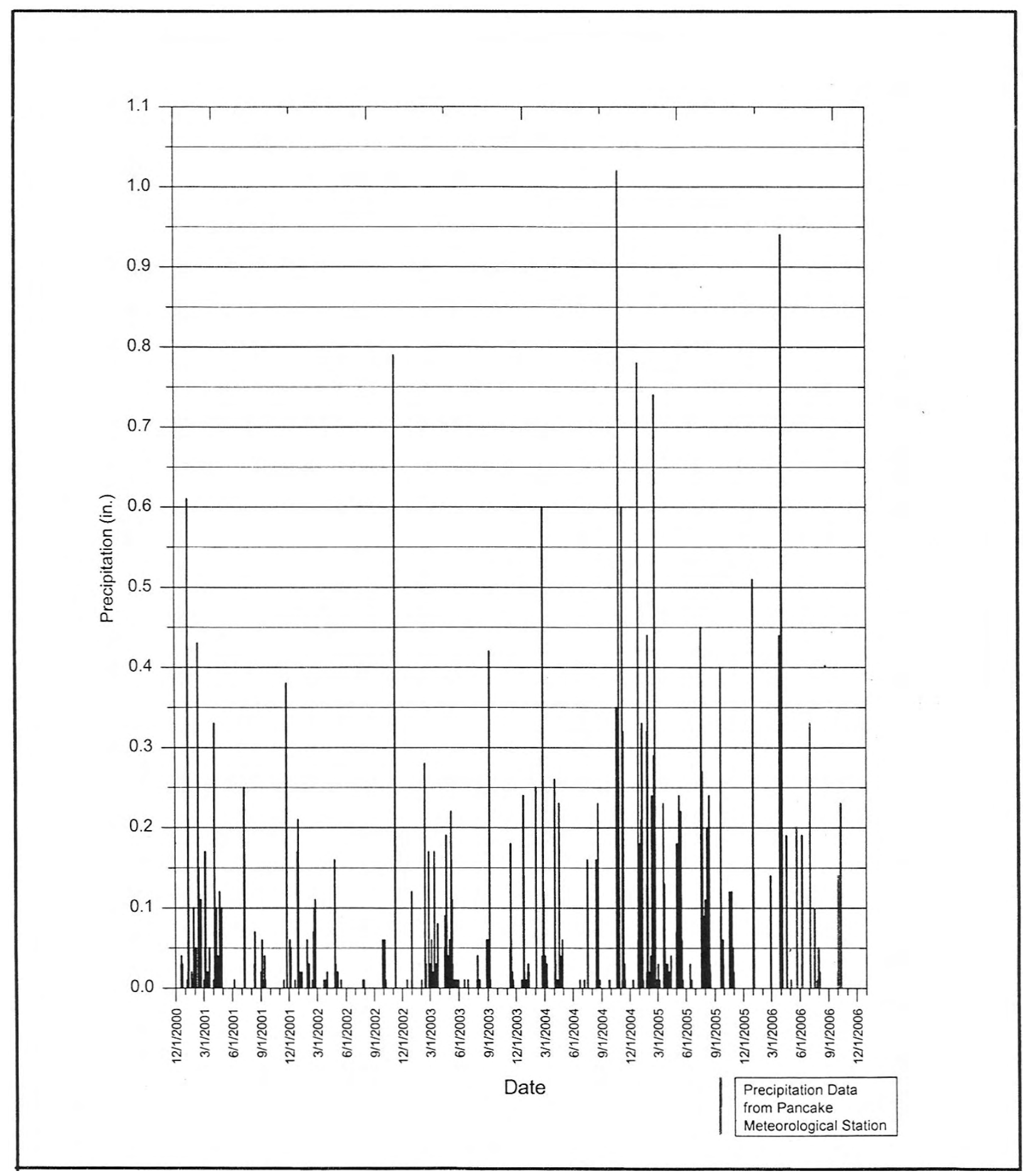

Figure B-1. UC-1 Precipitation 


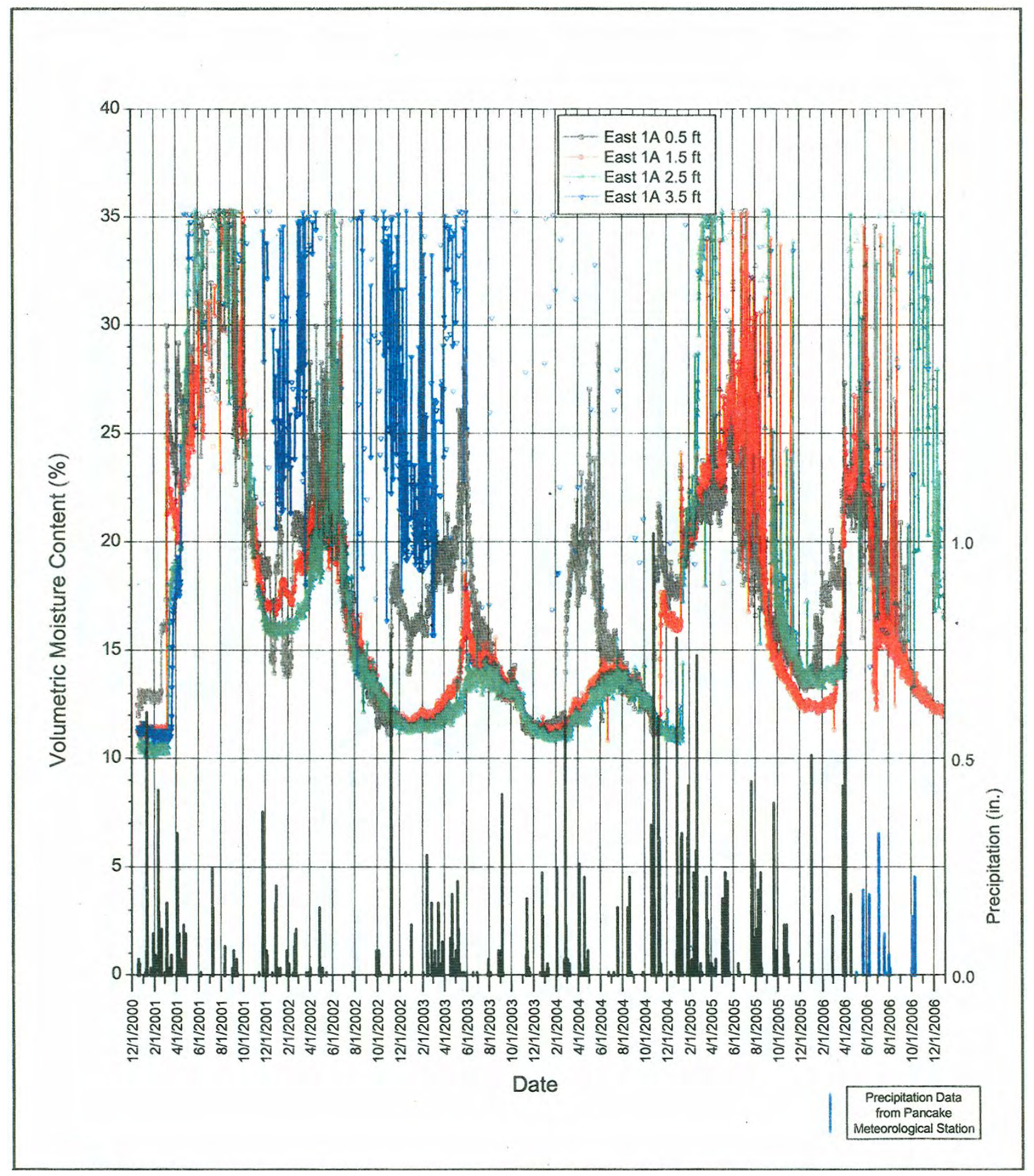

Figure B-2. Five-Year Soil Moisture Content, East TDR Nest A 


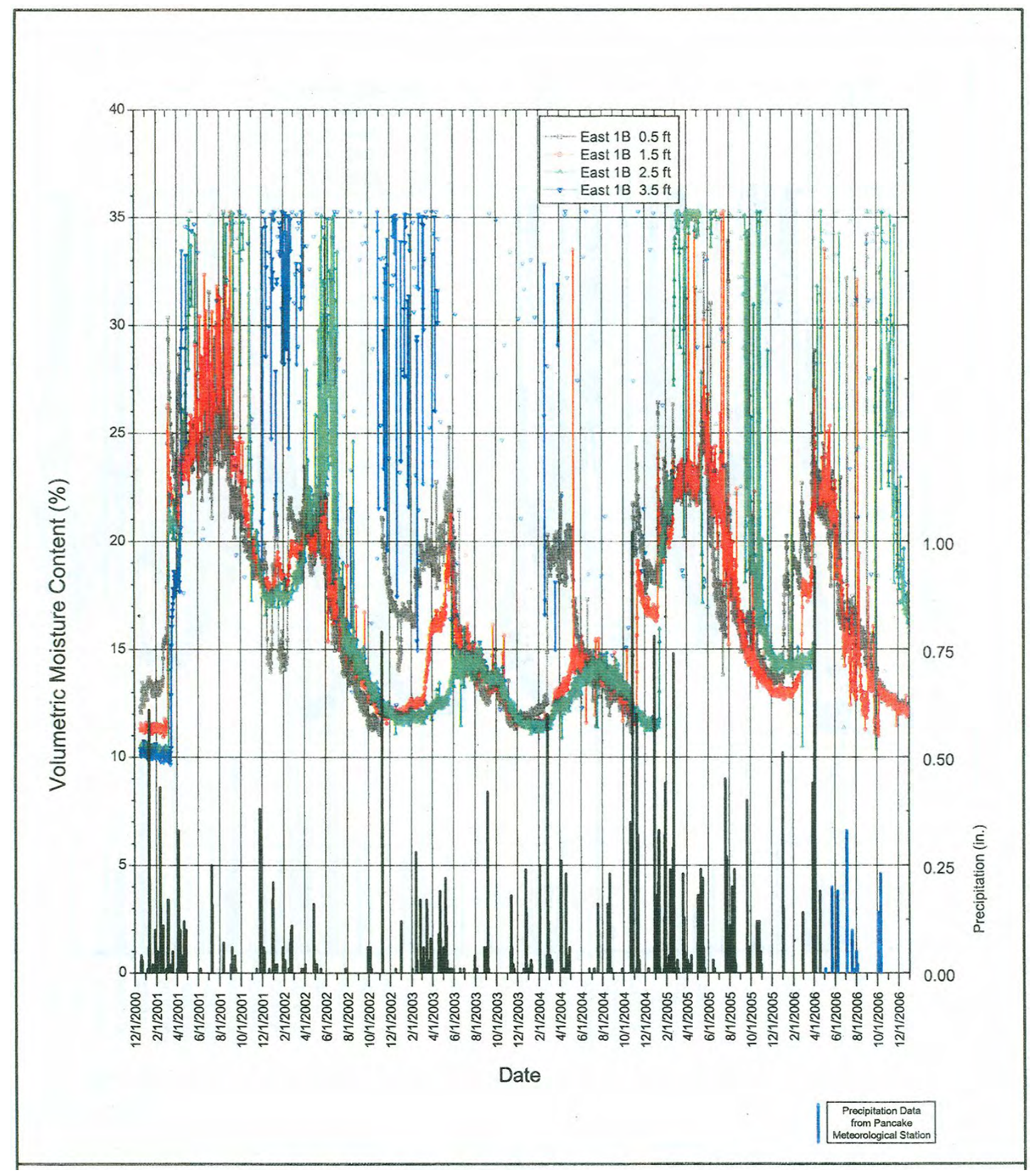

Figure B-3. Five-Year Soil Moisture Content, East TDR Nest B 


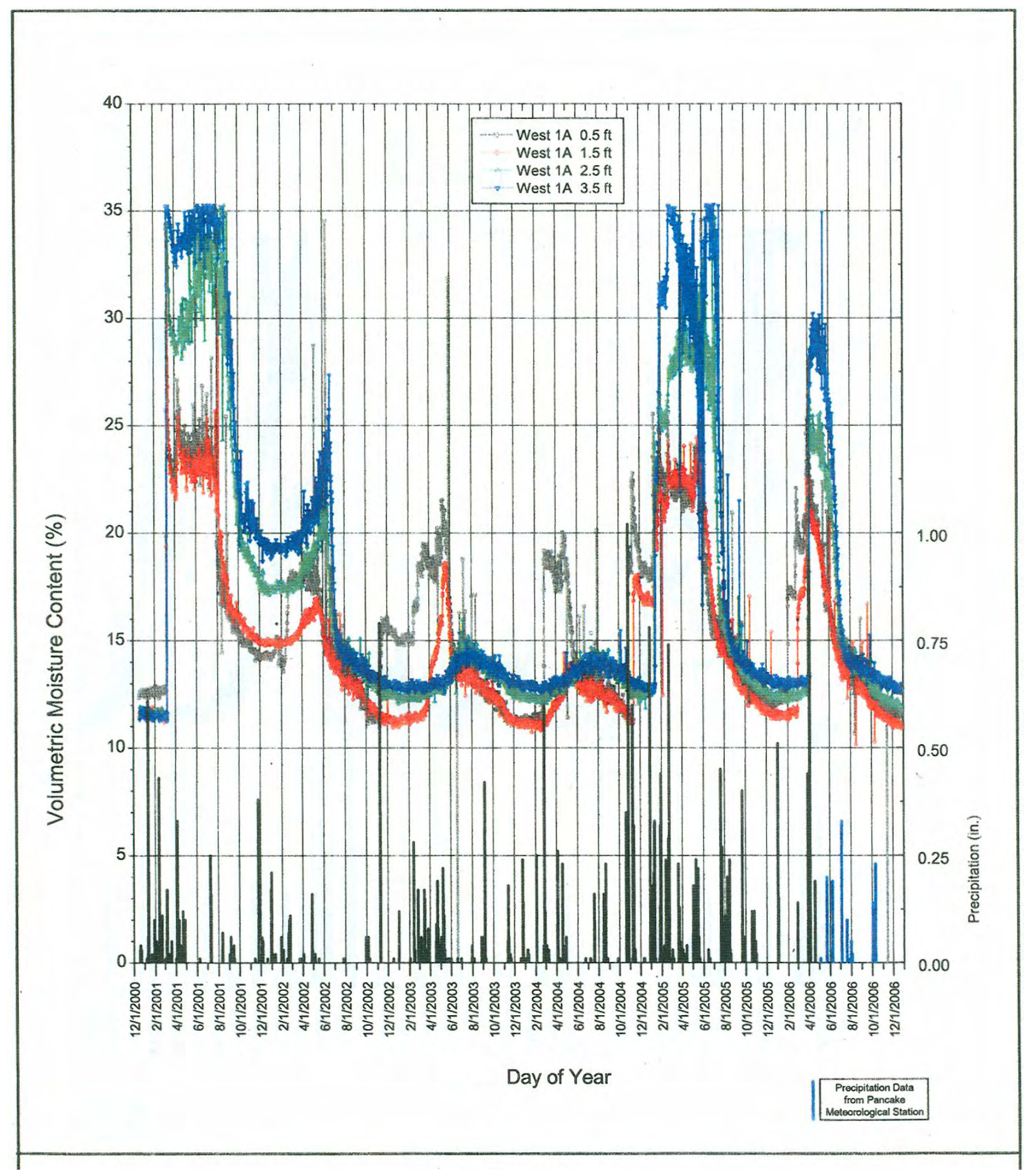

Figure B-4. Five-Year Soil Moisture Content, West TDR Nest A 


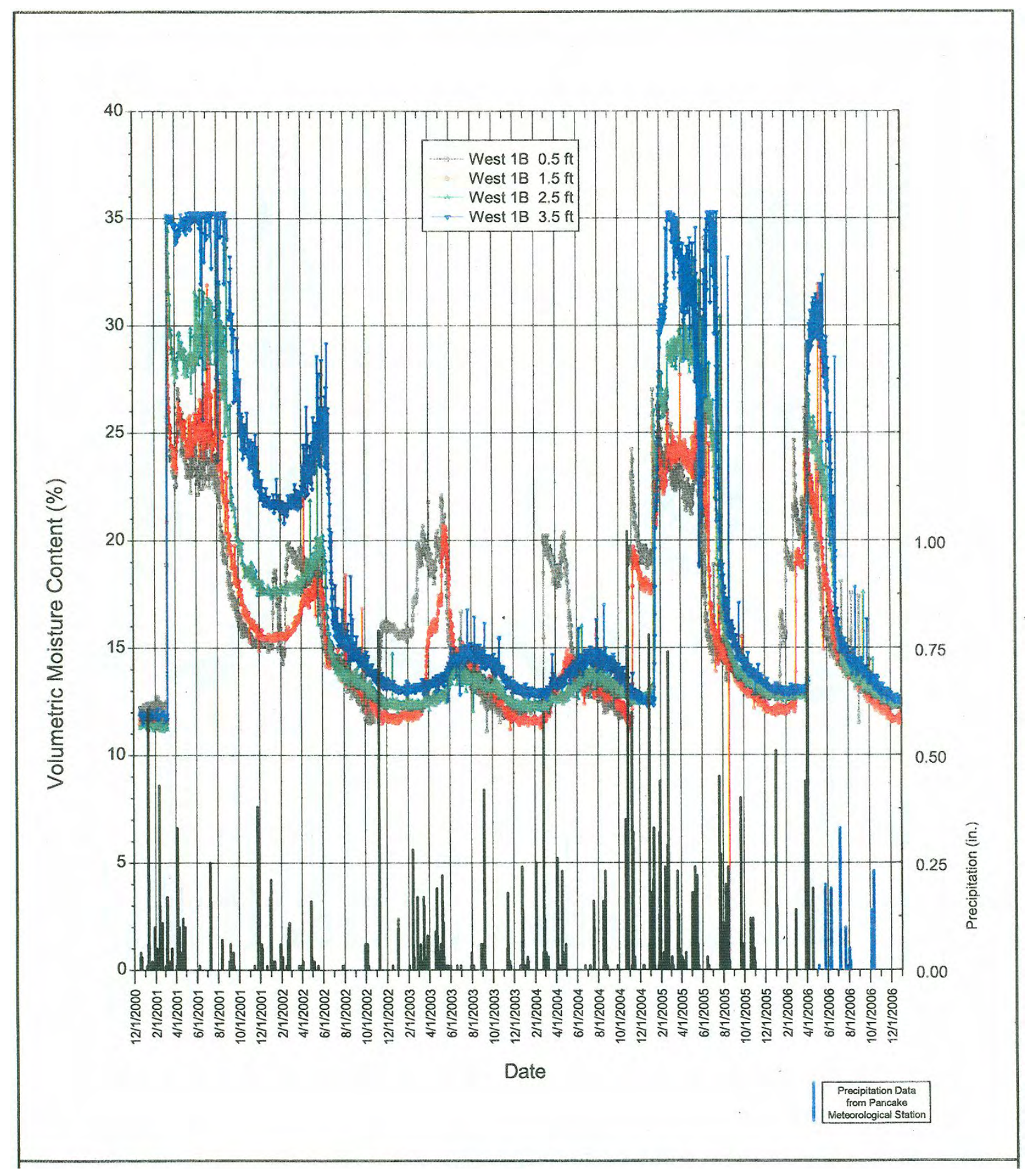

Figure B-5. Five-Year Soil Moisture Content, West TDR Nest B 
In general, wetting fronts can be seen as a rapid increase in the VMC near the surface followed by increased moisture at greater depths. All the profiles indicate a rapid increase in moisture content at the end of February 2001, as temperatures rose above the freezing point and allowed snow melt to infiltrate. This occurred before vegetation was established on the cover, showing the effect of infiltration on a nonvegetated cover. Both the east nest and west nest remained wet through July 2001. At that time, cover vegetation became established, and the cover began to dry out because of evapotranspiration over the hot summer months. TDR data for both nests show that the cover remained saturated at the 1.1-m (3.5-ft) depth. This was anticipated as the weight of the cover forced water out of the underlying drilling mud.

In general, beginning in 2002 and through 2004, less intense wetting fronts are seen at both nests during January and February. Infiltration can be seen each year through mid-June when, as a result of evapotranspiration from the vegetation and low seasonal precipitation, the soil moisture profile shows a rapid drying trend throughout the cover to a depth of $1.1 \mathrm{~m}(3.5 \mathrm{ft})$. With the exception of the 1.1-m (3.5-ft) probes in the east nests, by the end of January 2003 and January 2004, moisture content at depth is less than 15 percent and appears stable.

Data collected during 2005 indicate the cover system is performing as designed, and most VMC values decreased to less than 15 percent by the end of 2005. Because of several heavy precipitation events early in 2005, both the eastern and western nests initially showed saturated conditions throughout the cover profile. However, by June 2005, the cover dried out as a result of evapotranspiration from the cover vegetation. The one exception is at the $1.1-\mathrm{m}(3.5-\mathrm{ft}) \mathrm{depth}$ at the east nests, which continue to show saturated soil moisture conditions. The western nests show a uniformly dry profile with stable conditions below $0.76 \mathrm{~m}(2.5 \mathrm{ft})$ in depth.

Both TDR nests present similar profiles and indicate that the cover is performing as designed, with evapotranspiration effectively removing water from the cover. Because precipitation was unusually high and persistent in 2005, evapotranspiration was not as effective at removing soil moisture until the end of the year.

\section{B.2.2 Five-Year Data Trends}

\section{East TDR Nests}

The east TDR nests are located near the drainage channel at the approximate center of the cover. Run-on from precipitation events and water pressed out of the thickest portion of the underlying drilling mud were expected to produce the highest soil moisture content found on the CMP cover at the location where the east TDR nests were placed. Data obtained for both of the east nests indicate this to be the case. TDR data obtained for the 1.1-m (3.5-ft) depth are largely corrupted because of high moisture content (saturated conditions) and a high soil conductivity. The combination of these effects and the long cable length created problems in measuring the reflected signal from the TDR probes. As a result, the data are very noisy and practically missing at the 1.1-m (3.5-ft) depth for both east nests. For VMC values greater than 25 percent and high soil conductivities, the TDR data are outside the system operating limits, and the moisture content should be estimated as greater than 25 percent VMC.

Both east TDR nests indicate dry, stable conditions for the 2004 reporting period. The unusually heavy rainfall from January 2005 through May 2005 caused infiltration to a depth of 
approximately $0.76 \mathrm{~m}(2.5 \mathrm{ft})$ before the majority was removed from the cover by evapotranspiration. Moisture content measurements to approximately the $0.76 \mathrm{~m}(2.5 \mathrm{ft})$ depth are less than 15 percent VMC and appear to have stabilized.

Both east TDR nests present similar profiles and indicate that the cover is performing as designed; saturated conditions persist at the cover-mud interface, and evapotranspiration is effectively removing water from the cover.

\section{West TDR Nests}

The west TDR nests are located on the western flank of the CMP cover and represent the typical conditions to be expected over the majority of the cover.

The data obtained from both west nests were not affected by the signal loss problems observed on the east nests. The data presented are similar to those of the east nests - the initial very wet conditions extend from early March 2001 to approximately September 2001. Drying conditions extend from the cover surface to a depth of $1.1 \mathrm{~m}$ (3.5 ft) from October 2001 to approximately October 2002, at which time the cover vegetation was established. Conditions remain dry and stable through the current monitoring period, and VMC was less than 15 percent by the end of 2005.

Moisture content measurements indicate extremely wet conditions from January 2005 through May 2005, when infiltration reached to the 1.1-m (3.5-ft) depth before being removed by evapotranspiration.

Both west nests present a very similar profile and indicate the cover is performing as designed, and evapotranspiration is effectively removing water from the cover. The moisture content at all depths appears to be approaching steady state. 


\section{Appendix C}

\section{Vegetation Monitoring Report}


This page intentionally left blank 
2007 Revegetation Success Monitoring

Central Nevada Test Area

Corrective Action Unit 417

UC-1 Central Mud Pit

Field Work Conducted on

May 15, 2007 
This page intentionally left blank 


\section{C1.0 Introduction and Purpose}

The UC-1 Central Mud Pit (CMP), located within Corrective Action Unit 417 at the Central Nevada Test Area in Hot Creek Valley, was reclaimed in 2000. During reclamation, the hydrocarbon-containing drilling muds and other associated materials within the mud pit were covered with clean soil. In fall 2000, the constructed soil cover was seeded with a mix of native plant species, and in spring 2001, it was planted with 5,000 transplants. A fence was installed around the perimeter of the mud pit, enclosing an area approximately 2 hectares (5 acres) in size. Adjacent disturbances outside the fence to the south and west and a small area across the diversion channel to the southwest, totaling 1.5 hectares (3.7 acres), were also seeded in 2000.

Ecologists have monitored the success of the revegetation effort annually since October 2001. Results of these monitoring efforts have been documented in U.S. Department of Energy, National Nuclear Security Administration post-closure inspection and monitoring reports. Revegetation reached success criteria on the CMP and its perimeter areas in 2006 (Anderson 2006). The purpose of this year's revegetation assessment was to fulfill a post-closure monitoring requirement to document the health and stability of the CMP cover vegetation.

\section{C2.0 Monitoring Methods}

Because the revegetation effort on the CMP cover was considered successful in 2006, the revegetation monitoring methods used in May 2007 were less quantitative and intensive than the methods used in previous years. First, simple observations of plant health were made, and second, a comparison of vegetation cover in the CMP area with vegetation cover in a nearby, undisturbed area was made. Vegetation cover was measured semi-quantitatively by making ocular estimates in 1-meter-square sampling quadrats. Quadrats were located randomly throughout the sampled areas by choosing a direction and then pacing a random number of steps. Ten quadrats were placed on the CMP cover, and 10 were placed in the nearby undisturbed area. No quadrats were placed in the perimeter area outside the CMP fence; instead, the ecologist walked the entire area and estimated the average overall vegetation cover.

This report contains common names of the plant species identified in the field. The scientific names associated with the common names are listed in Table $\mathrm{C}-1$. Photographs are in Section C4.0.

Table C-1. Common and Scientific Names of Plant Species Identified at Central Nevada Test Area

\begin{tabular}{|l|l||}
\hline \multicolumn{1}{|c|}{ Common Name } & \multicolumn{1}{c|}{ Scientific Name } \\
\hline \hline \multicolumn{2}{|c|}{ Shrubs } \\
\hline Big sagebrush & Artemisia tridentata \\
\hline Douglas rabbitbrush & Chrysothamnus viscidiflorus \\
\hline Fourwing saltbush & Atriplex canescens \\
\hline Rubber rabbitbrush & Ericameria nauseosa \\
\hline \multicolumn{2}{|c|}{ Grasses } \\
\hline Bottlebrush squirreltail & Elymus elymoides \\
\hline Galleta grass & Pleuraphis jamesii \\
\hline Indian ricegrass & Achnatherum hymenoides \\
\hline & Forbs \\
\hline Halogeton & Halogeton glomeratus \\
\hline Prickly pear cactus & Opuntia polyacantha \\
\hline
\end{tabular}




\section{C3.0 Results and Recommendations}

Vegetation on the CMP cover was assessed on May 15, 2007. Plants within the revegetated areas, both within and outside the fenced area, appeared to be stressed from drought. Since October 2006, this area of Nevada has received only 1.6 inches of precipitation, or 27 percent of its average precipitation. Between October 2005 and September 2006, the area received a total of 3.5 inches, approximately 60 percent of average (National Weather Service 2007).

Approximately half of the Indian ricegrass plants observed within the fenced area appeared to be dormant or dead (i.e., they had not yet sprouted this year's green stems or leaves) and all of the rabbitbrush and fourwing saltbush plants had only begun to show evidence of new spring growth. Photograph 1 shows drought-stressed fourwing saltbush and rubber rabbitbrush plants on the CMP cover. Sagebrush plants did not show as much stress and appeared healthy. Average total plant cover on the CMP cover was estimated at 18 percent (Table C-2). Photographs 2-4 show views of the CMP cover vegetation.

Table C-2. Vegetation Cover (Percent) in 1-Meter-Square Quadrats on the CMP Cover

\begin{tabular}{|l|c|c|c|c|c|c|c|c|c|c||}
\hline \multicolumn{1}{|c|}{ Species/Quad } & Q1 & Q2 & Q3 & Q4 & Q5 & Q6 & Q7 & Q8 & Q9 & Q10 \\
\hline \hline Big sagebrush & 2 & 1 & 2 & & & & 3 & 4 & 5 & \\
\hline Douglas rabbitbrush & 5 & 3 & 6 & & 5 & & 6 & 3 & 2 & 8 \\
\hline Rubber rabbitbrush & & 8 & 2 & & 11 & & 12 & 14 & 8 & 17 \\
\hline Fourwing saltbush & 10 & 2 & 4 & 13 & 3 & & 2 & 2 & 3 & \\
\hline Indian ricegrass & 3 & 1 & 1 & & 1 & & 1 & 2 & & \\
\hline Total Plant Cover \% & $\mathbf{2 0}$ & $\mathbf{1 5}$ & $\mathbf{1 5}$ & $\mathbf{1 3}$ & $\mathbf{2 0}$ & $\mathbf{0}$ & $\mathbf{2 4}$ & $\mathbf{2 5}$ & $\mathbf{1 8}$ & $\mathbf{2 5}$ \\
\hline Litter & 20 & 12 & 5 & 7 & 8 & 5 & 6 & 20 & 12 & 30 \\
\hline Rock & 20 & 30 & 30 & 40 & 35 & 45 & 30 & 25 & 30 & 20 \\
\hline Bare ground & 40 & 43 & 50 & 40 & 37 & 50 & 40 & 30 & 40 & 25 \\
\hline
\end{tabular}

Other species observed: halogeton.

As in previous years, the vegetation in areas peripheral to the fenced site had been grazed heavily by rabbits and antelope (or deer). The ground was covered with scat, and only a trace of grass was found. Total plant cover was estimated at 15 percent (Table $\mathrm{C}-3$ ). This vegetation also was visibly drought stressed. Photographs 5 through 7 show site conditions.

Table C-3. Vegetation Cover (Percent) in CMP Perimeter Area

\begin{tabular}{|l|c|}
\hline \multicolumn{1}{|c|}{ Species } & Percent Cover \\
\hline \hline Big sagebrush & 4 \\
\hline Douglas rabbitbrush & trace \\
\hline Rubber rabbitbrush & 9 \\
\hline Fourwing saltbush & 2 \\
\hline Indian ricegrass & trace \\
\hline Halogeton & trace \\
\hline \multicolumn{1}{|c|}{ Total Plant Cover } & 15 \\
\hline Litter & 20 \\
\hline Rock & 20 \\
\hline Bare ground & 45 \\
\hline
\end{tabular}


The vegetation in nearby undisturbed areas was sampled to provide a comparison to the revegetated areas. Unlike in the revegetated areas, no fourwing saltbush or rubber rabbitbrush was present. This area was dominated by sagebrush and contained a slightly higher percentage and diversity of grasses (Table $\mathrm{C}-4$ ). The sagebrush appeared healthy, whereas the Douglas rabbitbrush and grasses appeared drought stressed.

Table C-4. Vegetation Cover (Percent) in 1-Meter-Square Quads in Undisturbed Area

\begin{tabular}{|l|c|c|c|c|c|c|c|c|c|c||}
\hline \multicolumn{1}{|c|}{ Species/Quad } & Q1 & Q2 & Q3 & Q4 & Q5 & Q6 & Q7 & Q8 & Q9 & Q10 \\
\hline \hline Big sagebrush & 24 & 35 & 27 & 11 & 5 & 12 & 30 & 3 & 9 & 14 \\
\hline Douglas rabbitbrush & 5 & 3 & & & 4 & & 4 & & 9 & 2 \\
\hline Galleta grass & & & 1 & 4 & 3 & & & & 2 & 1 \\
\hline Indian ricegrass & 1 & 1 & & & & & & & & \\
\hline Bottlebrush squirreltail & & 1 & 2 & & 1 & 1 & 1 & & 2 & 1 \\
\hline Total Plant Cover \% & $\mathbf{3 0}$ & $\mathbf{4 0}$ & $\mathbf{3 0}$ & $\mathbf{1 5}$ & $\mathbf{1 3}$ & $\mathbf{1 3}$ & $\mathbf{3 5}$ & $\mathbf{3}$ & $\mathbf{2 2}$ & $\mathbf{1 8}$ \\
\hline Litter & 20 & 10 & 10 & 5 & 5 & 7 & 15 & 1 & 5 & 10 \\
\hline Rock & 2 & 15 & 25 & 20 & 55 & 25 & 15 & 51 & 23 & 17 \\
\hline Bare ground & 48 & 35 & 35 & 60 & 27 & 55 & 35 & 45 & 50 & 65 \\
\hline
\end{tabular}

Other species observed: prickly pear cactus.

Given the paucity of precipitation during the last 1.5 years, revegetation of the CMP cover and perimeter area is still considered successful. In previous monitoring reports (Anderson 2005, 2006), revegetation success was measured by determining if plant cover in revegetated areas met or exceeded 70 percent of the plant cover in undisturbed areas. With this criterion, total plant cover in revegetated areas would need to be 15.4 percent or more to be considered successful. Plant cover on the CMP cover exceeds this amount, and plant cover in perimeter areas meets this amount (Table $\mathrm{C}-5$ ).

Table C-5. Comparison of Average Vegetation Cover (Percent)

\begin{tabular}{|l|c|c|c|}
\hline \multicolumn{1}{|c|}{ Sampled Area } & Total Plant Cover & Shrub Cover & Grass Cover \\
\hline UC-1 CMP & 18 & 17 & 1 \\
\hline CMP Perimeter & 15 & 15 & 0 \\
\hline Undisturbed Area & 22 & 20 & 2 \\
\hline
\end{tabular}

Given the relative success of the revegetation effort at UC-1, it is not necessary to conduct plant cover assessments every year. Inspectors should continue to observe plants in revegetated areas each year and report obvious changes in plant health or cover. If obvious changes are noted, an ecologist or reclamation specialist should visit the site and determine if action is needed. 


\section{C4.0 Photographs of Site Vegetation}

\begin{tabular}{|c|l||}
\hline $\begin{array}{c}\text { Photo } \\
\text { No. }\end{array}$ & \multicolumn{1}{|c|}{ Photograph Description } \\
\hline \hline 1 & Fourwing saltbush and rubber rabbitbrush plants showing drought stress \\
\hline 2 & View SE of CMP cover vegetation from N entry gate \\
\hline 3 & View S of CMP cover vegetation from N entry gate \\
\hline 4 & View SW of CMP cover vegetation from N entry gate \\
\hline 5 & View E of S perimeter area vegetation \\
\hline 6 & View NE of SE perimeter area vegetation \\
\hline 7 & View E of N perimeter area vegetation \\
\hline 8 & View E of undisturbed area N of CMP cover \\
\hline
\end{tabular}

\section{C5.0 References}

Anderson, D., 2005. Revegetation Success Monitoring, Corrective Action Unit 417 Central Nevada Test Area - Surface, Hot Creek Valley, Nevada, included as Appendix to Post-Closure Inspection and Monitoring Report for Corrective Action Unit 417: Central Nevada Test AreaSurface, Hot Creek Valley, Nevada For Calendar Year 2005, DOE/NV-1122, U.S. Department of Energy, National Nuclear Security Administration, Nevada Site Office, April 2006.

Anderson, D., 2006. Revegetation Success Monitoring, Central Nevada Test Area Corrective Action Unit 417, included as Appendix C to Draft Post-Closure Inspection and Monitoring Report for Corrective Action Unit 417: Central Nevada Test Area - Surface, Hot Creek Valley, Nevada, DOE/NV/25946-168, U.S. Department of Energy, National Nuclear Security Administration, Nevada Site Office, April 2007.

National Weather Service, 2007. California Nevada River Forecast Center website: www.cnrfc.noaa.gov/rainfall_data.php, data for Tonopah, Nevada. 

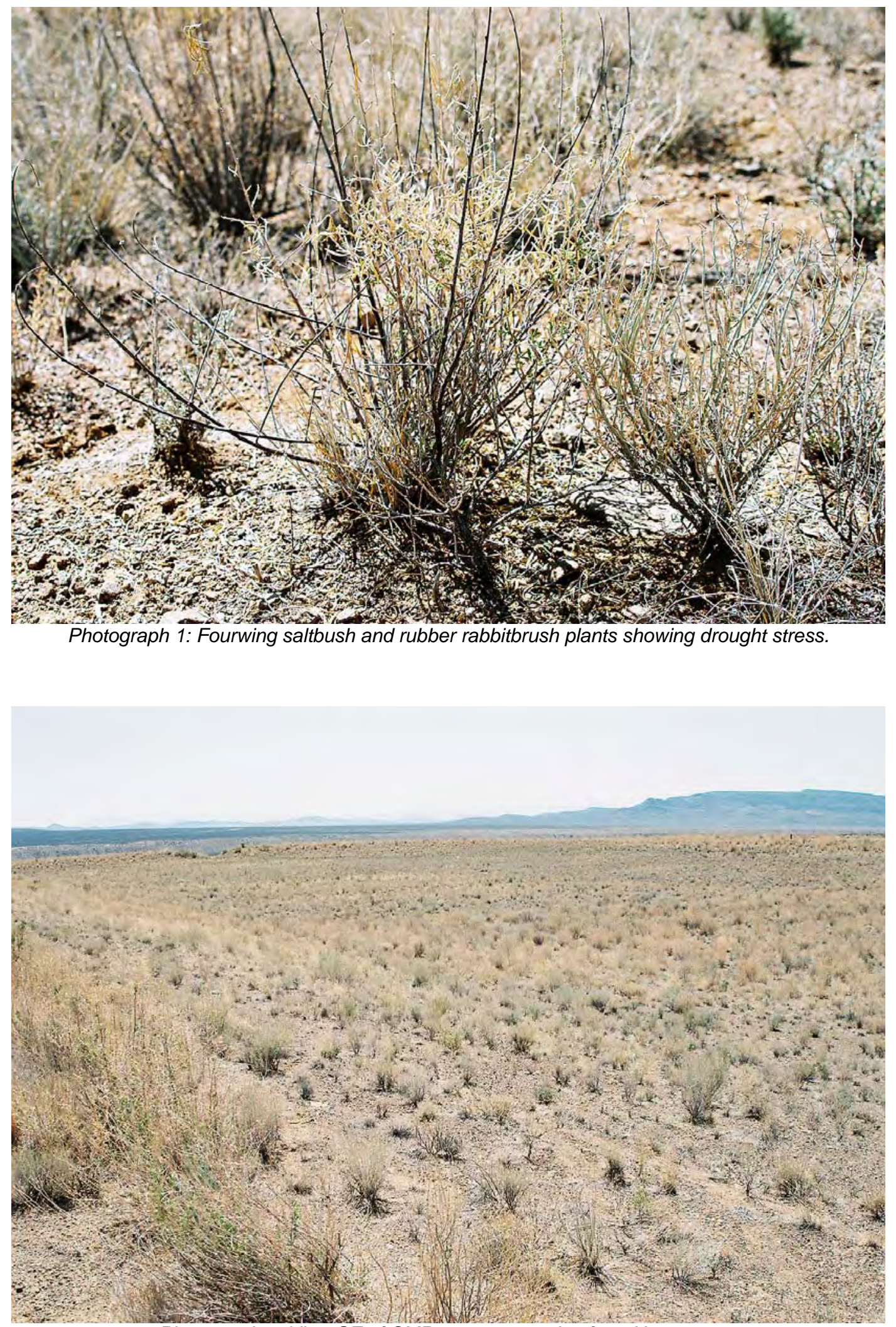

Photograph 2: View SE of CMP cover vegetation from $N$ entry gate 


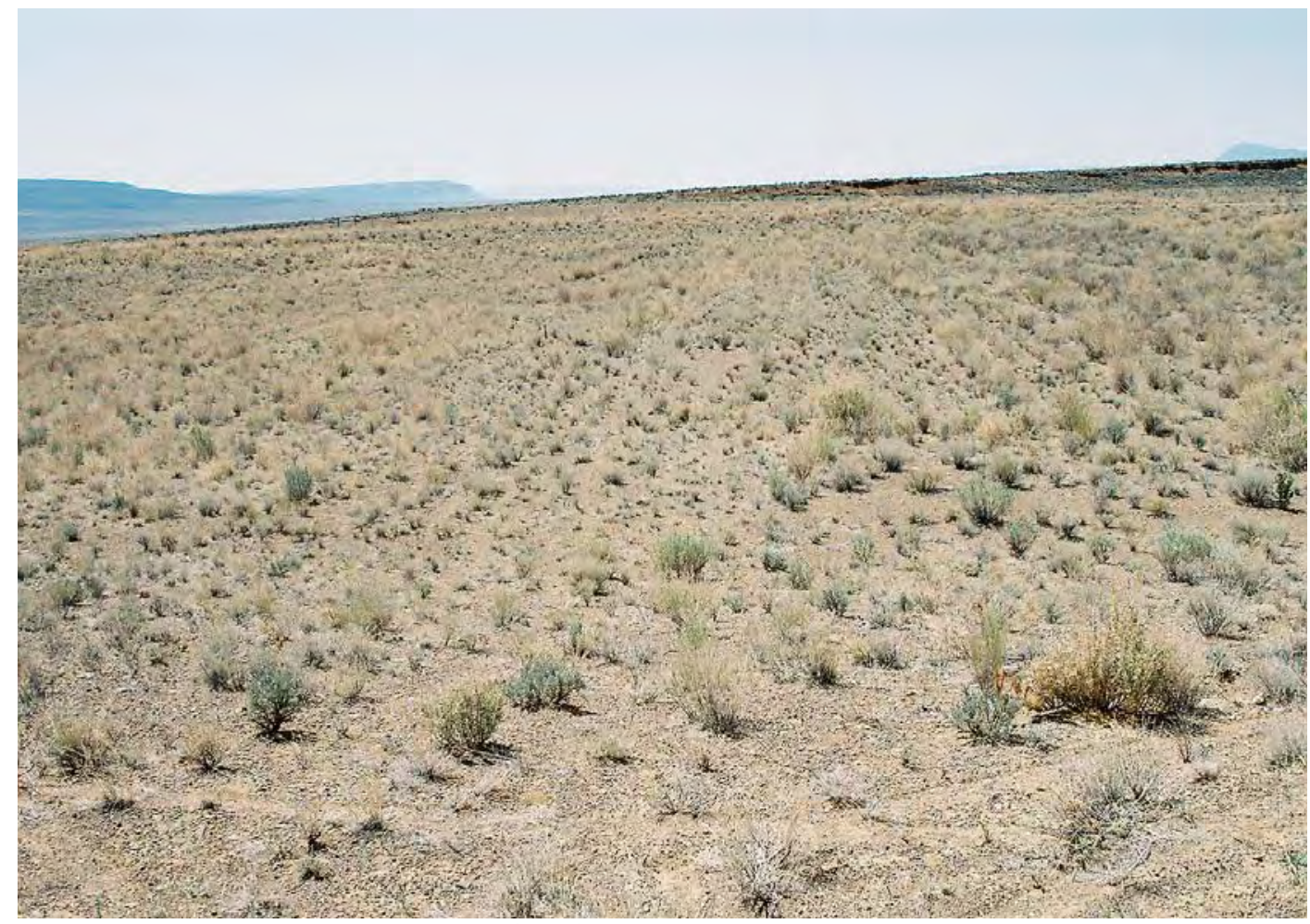

Photograph 3: View S of CMP cover vegetation from $N$ entry gate

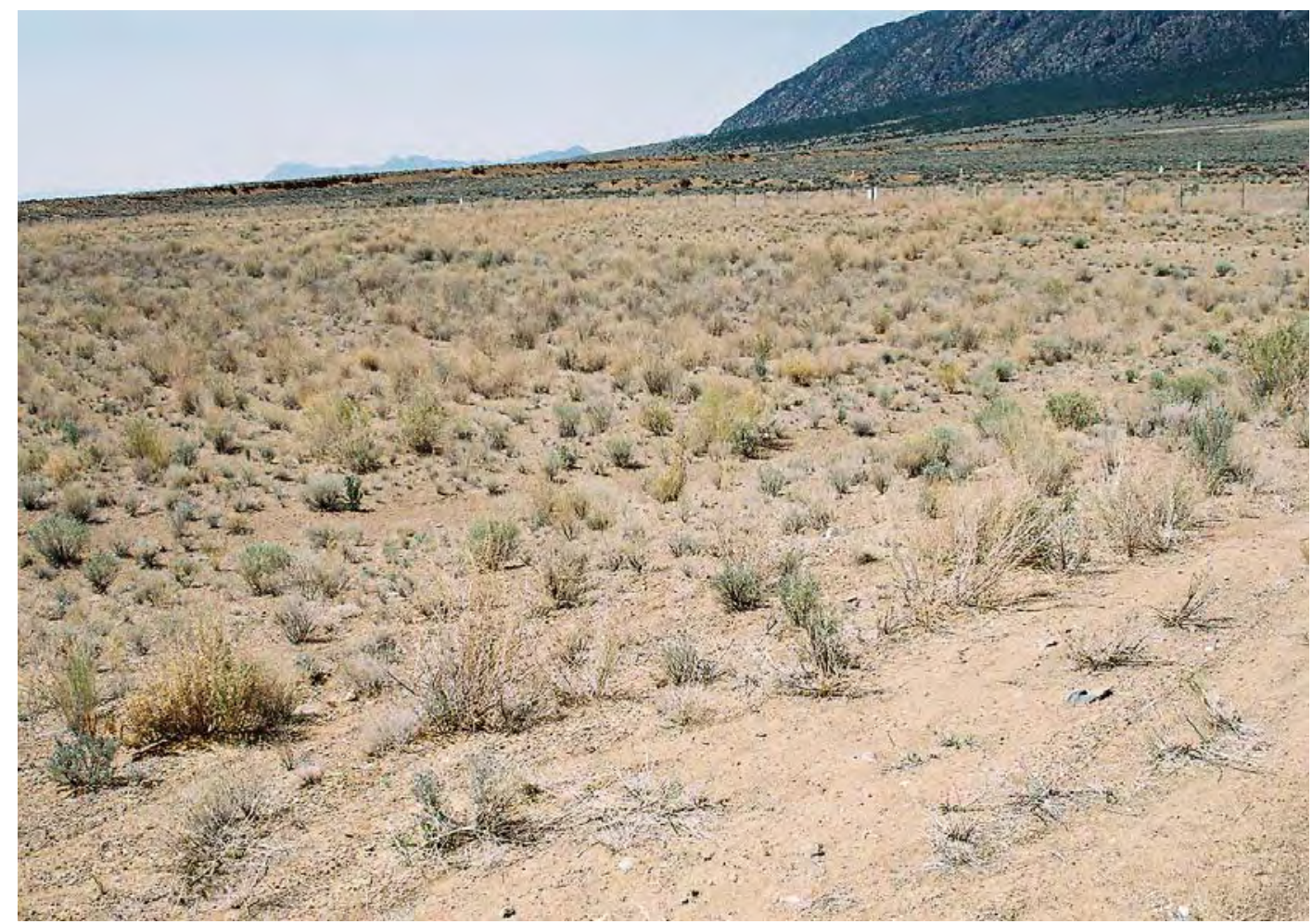

Photograph 4: View SW of CMP cover vegetation from $N$ entry gate 


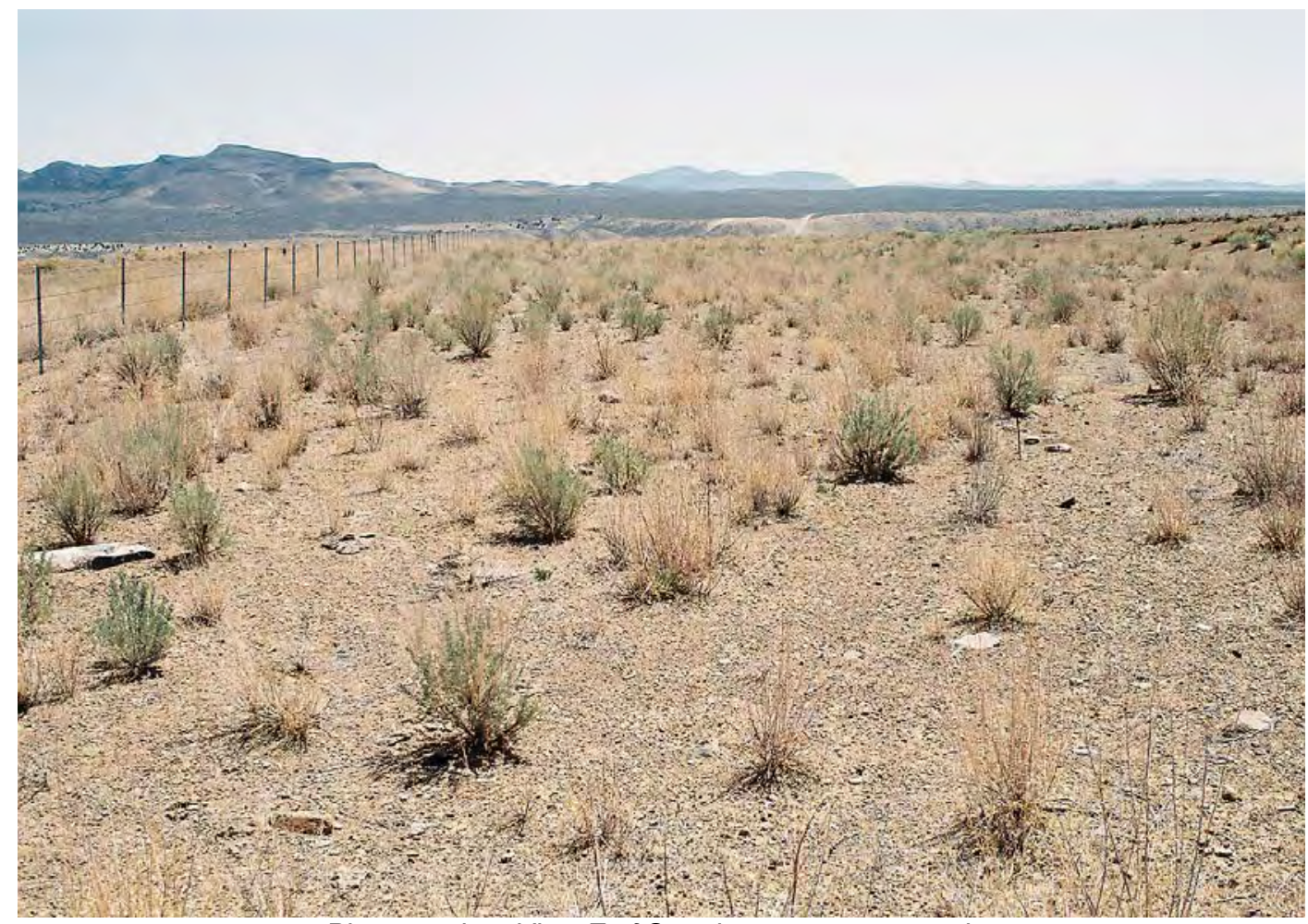

Photograph 5: View $E$ of $S$ perimeter area vegetation

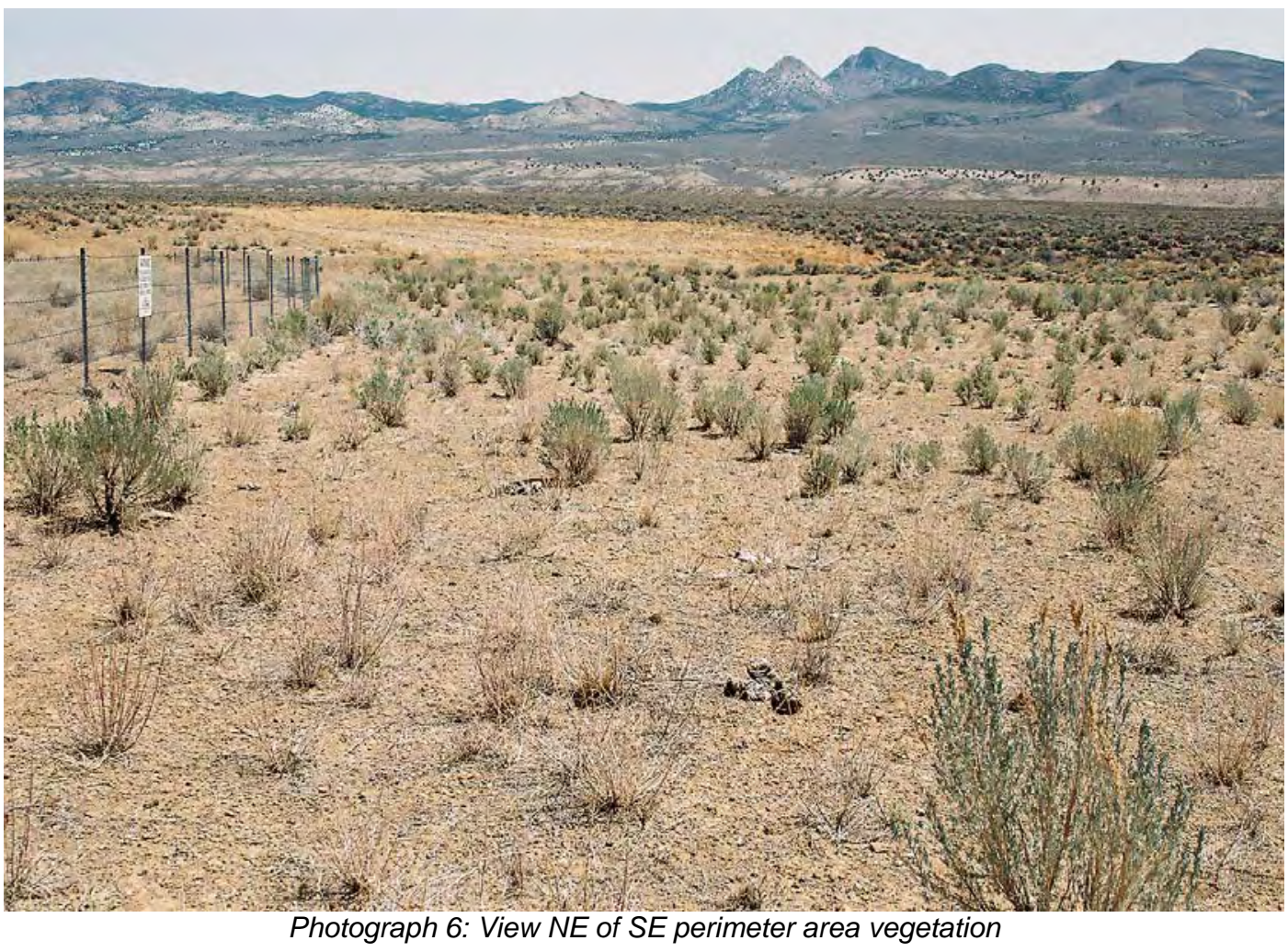




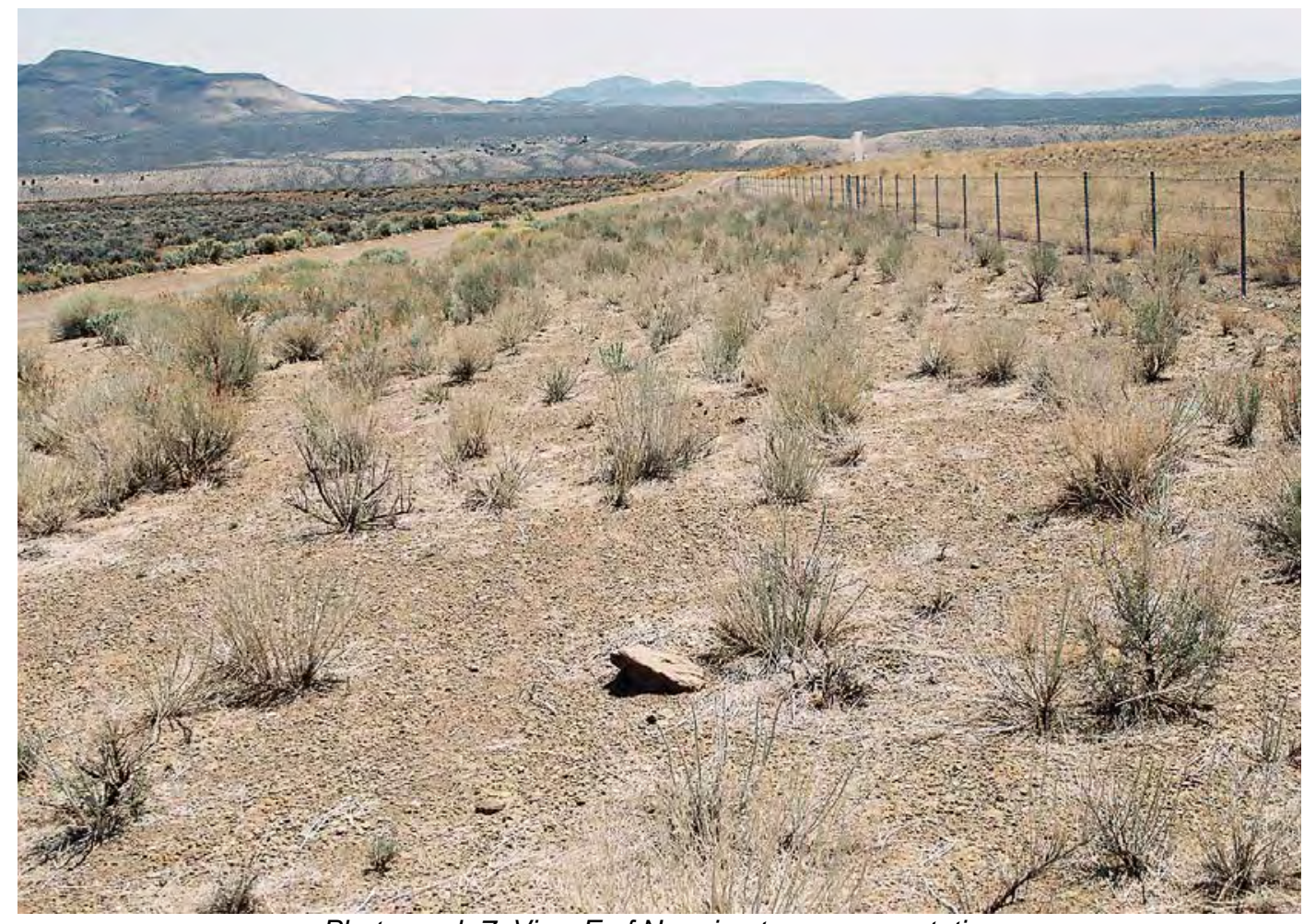

Photograph 7: View $E$ of $N$ perimeter area vegetation

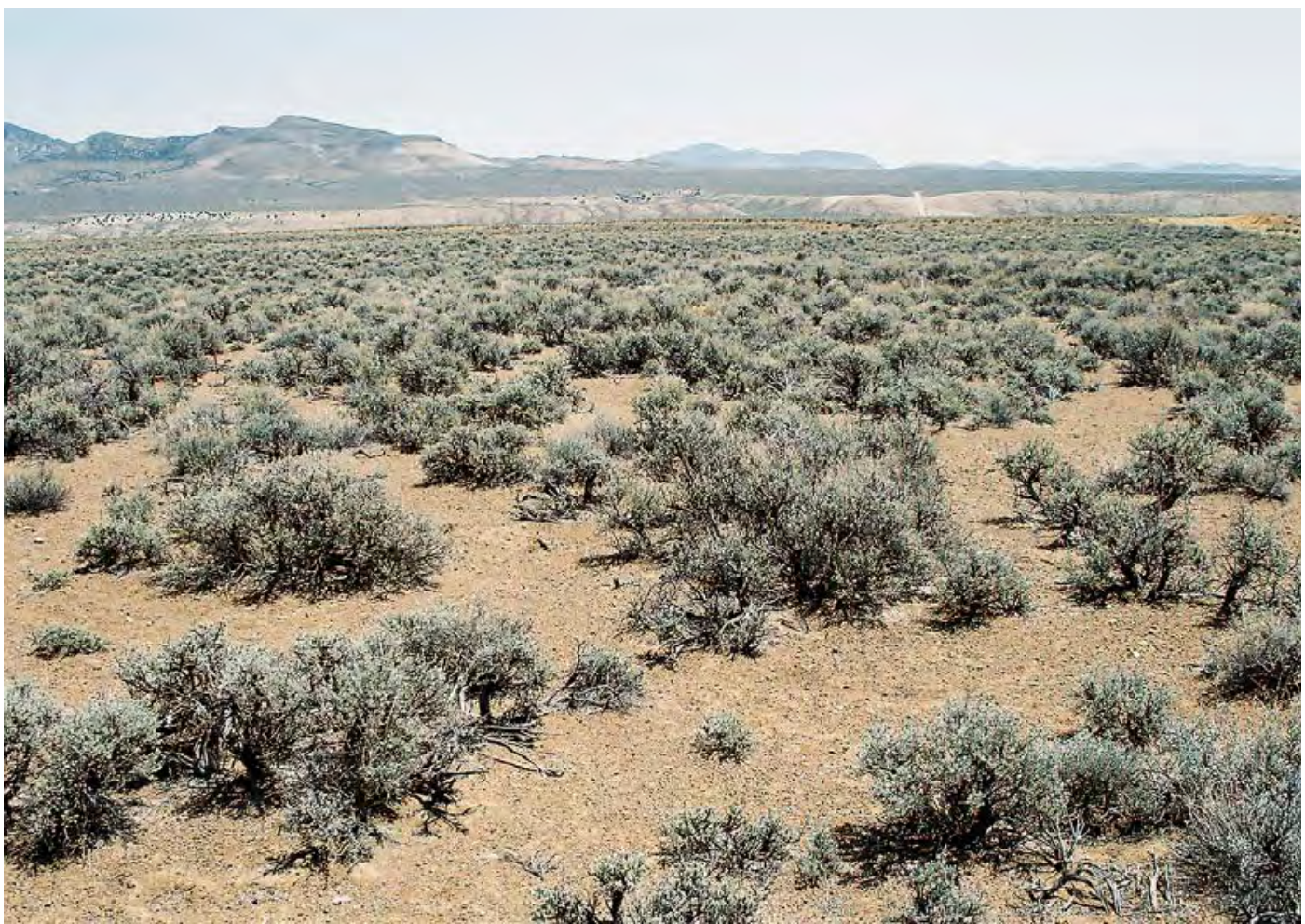

Photograph 8: View E of undisturbed area N of CMP cover 
Appendix D

Correspondence and Record of Review 
This page intentionally left blank 


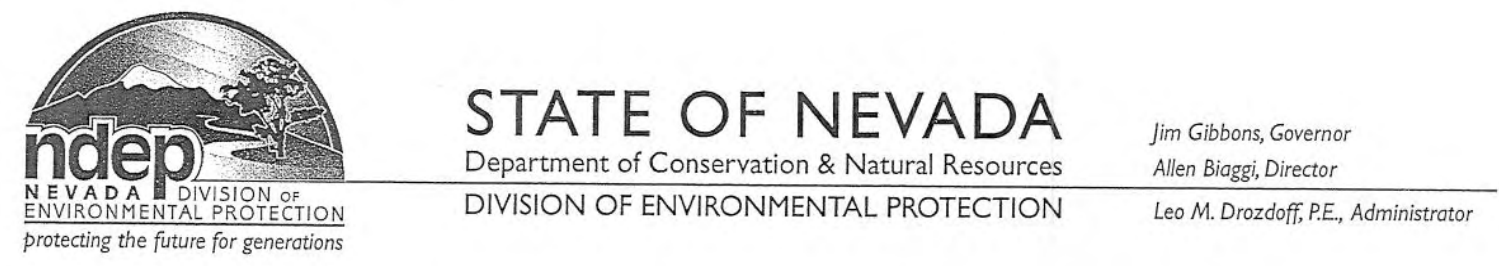

July 21,2008

Mr. Mark Kautsky

Site Manager

U.S. Department of Energy

Office of Legacy Management

2597 B $3 / 4$-Road

Grand Junction, CO 81503

RE: Post-Closure Inspection and Monitoring Report for Corrective Action Unit 417: Central Nevada Test Area Surface, Hot Creek Valley, Nevada for Calendar Year 2007 April 2008 Federal Facility Agreement and Consent Order

Dear Mr. Kautsky:

The Nevada Division of Environmental Protection, Bureau of Federal Facilities (NDEP) staff has received and reviewed the above-referenced document on the post-closure inspection and monitoring activities conducted at the Central Nevada Test Area during calendar year 2007. This document was prepared in accordance with the Federal Facility Agreement and Consent Order (FFACO) and the Closure Report for Corrective Action Unit 417. NDEP accepts the document as satisfying the annual reporting requirements and has the following comments:

1. Sections 2.3 and 2.4: The subject of the second paragraph of Section 2.3 and the first paragraph of Section 2.4 is very similar and while these two paragraphs begin in identical ways, the material presented in the middle of each paragraph can be considered contradictory. Specifically, Section 2.4 states that cover compliance will be based on the soil moisture content of the cover once steady-state conditions are reached and that it is expected to be achieved within 10 years of cover construction, which was completed in September 2000, as per cover performance modeling presented in the Corrective Action Plan. Section 2.3 does not state a timeframe for the soil moisture in the cover to reach equilibrium, only that specific cover compliance criteria will not be set until it is reached. Both paragraphs do state that once equilibrium has been reached, soil moisture compliance values will be agreed upon with the NDEP however, both Sections should be worded consistently.

2. Page 3-2, Section 3.2.1, second paragraph, third sentence: "...SM-2, SM-3, and SM-4, show..." The SM-4 should be SM-5. Please correct this in the sentence.

3. Section 3.2.2 and Figure 3.3: It is stated in Section 3.2.2 that the total subsidence of the west monument is $6.6 \mathrm{~cm}$ (2.6 in) and the east monument, $3.1 \mathrm{~cm}(1.2 \mathrm{in})$ since the baseline survey in October 1999. Figure 3.3 depicts the subsidence of the west monument as approximately $0.6 \mathrm{~m}$ or 2.6 inches but the east monument as approximately $0.9 \mathrm{~m}$ or 3.85 inches. The text of Section 3.2 .2 and Figure 3.3 should be in agreement. 
Mr. Mark Kautsky

Page 2 of 3

July 21, 2008

4. Page 3-6, Table 3-2 and Page 3-7, Figure 3-3: The values for east monument subsidence presented in Table 3-2 are not reflected in the plot in Figure 3-3. Please correct this discrepancy.

5. Page 3-8, Section 3.4, third paragraph, first sentence: There is no Figure $4-1$ in the document. The 2007 precipitation is presented in Figure 3-4. Please correct this in the document.

6. Section 4.1 and Section C3.0: It is suggested in the second paragraph of Section 4.1 that future vegetation surveys be conducted once every 2 years or as needed to help monitor the health of the vegetation. The last paragraph of Section C3.0 also conveys this recommendation. This recommendation was presented in the Post-Closure Inspection and Monitoring Report for Calendar Year 2006 and approved by the NDEP in a letter dated August 2, 2007. The NDEP still accepts this recommendation and expects that a vegetation survey will be conducted during the 2008 inspection.

7. Section 4.3: The first three Recommendations were presented in the Post-Closure Inspection and Monitoring Report for Calendar Year 2006 and approved by the NDEP in a letter dated August 2, 2007. The NDEP still accepts these recommendations.

8. Section 4.3: In regards to the last two Recommendations presented in the Report, the NDEP concurs with meeting with the Office of Legacy Management (OLM) to discuss the closure plan with respect to historical site data collected, present site condition, including the non-working east TDR nest, and future path forward. In the meantime, OLM should continue to collect data from the east TDR nest if at all possible. It is the NDEP's belief that while it may now be thought to be useless data, it may become valuable in the future. Once OLM has established soil moisture monitoring compliance criteria, as well as TDR compliance criteria, based on all the historical data, a meeting should be scheduled with the NDEP to discuss these compliance criteria and a future path forward.

9. Page C-6, Section C3.0, first paragraph: The National Weather Service 2007 reference cited lists the annual average precipitation for Tonopah as 5.84 inches. Using this figure, the 1.6 inches of precipitation received since October 2006 would be 27 percent, not 41 percent as stated in the text. The text should be corrected.

Please address any questions regarding this matter to, or schedule the meeting through, Chris Andres at (702) 486-2850 ext. 232.

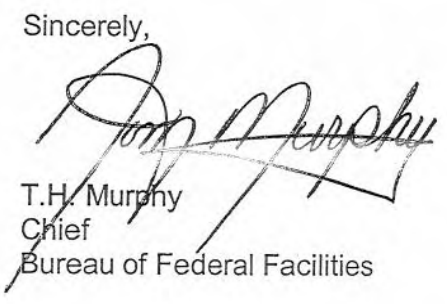


Mr. Mark Kautsky

Page 3 of 3

July 21, 2008

MM/EAJ:cda

cC: Jeffrey Fraher, DTRA/CXTS, Kirtland AFB, NM

W. R. Griffin, SNJV, Las Vegas, NV

J. B. Chapman, DRI, Las Vegas, NV

E. F. DiSanza, WMP, NNSA/NSO, Las Vegas, NV

J. B. Jones, ERP, NNSA/NSO, Las Vegas, NV

NSTec Technical Information Officer, Las Vegas, NV

FFACO Group, SNJV, Las Vegas, NV

D. Crawford, Stoller, Grand Junction, CO

R. Hutton, Stoller, Grand Junction, CO 
This page intentionally left blank 


\section{U.S. Department of Energy Office of Legacy Management}

\begin{tabular}{|c|c|c|c|c|c|}
\hline \multicolumn{6}{|c|}{ Record of Review } \\
\hline $\begin{array}{l}\text { Due Date } \\
08 / 15 / 08\end{array}$ & $\begin{array}{l}\text { Review No. } \\
1\end{array}$ & $\begin{array}{l}\text { Project } \\
\text { Legacy Management }\end{array}$ & \multicolumn{3}{|c|}{$\begin{array}{l}\text { Type of Review } \\
\text { Technical }\end{array}$} \\
\hline \multicolumn{3}{|c|}{$\begin{array}{l}\text { Document Title andior Number and Revision } \\
\text { Post-Closure Inspection and Monitoring Report for Corrective Action Unit 417: Central } \\
\text { Nevada Test Area Surface, Hot Creek Valley, Nevada for Calendar Year } 2007\end{array}$} & \multirow{2}{*}{\multicolumn{3}{|c|}{$\begin{array}{l}\text { Reviewers' Recommendation } \\
\square \text { Release Without Comment } \\
\square \text { Consider Comments } \\
\square \text { Resolve Comments and Reroute for Review }\end{array}$}} \\
\hline \multicolumn{2}{|c|}{ Author's Organization } & $\begin{array}{l}\text { Author's Phone } \\
\text { (970) } 248-7666\end{array}$ & & & \\
\hline \multicolumn{3}{|c|}{$\begin{array}{l}\text { Reviewer } \\
\text { Tim Murphy }\end{array}$} & \multicolumn{3}{|c|}{$\square$ Comments Have Been Addressed } \\
\hline \multirow{2}{*}{\multicolumn{2}{|c|}{$\begin{array}{l}\text { Reviewer's Organization } \\
\text { NDEP }\end{array}$}} & \multirow[t]{2}{*}{$\begin{array}{l}\text { Reviewer's Phone } \\
(702) 486-2850\end{array}$} & \multicolumn{3}{|c|}{$\begin{array}{l}\square \text { Comment Resolution Satisfactory } \\
\square \text { Comment Resolution Unsatisfactory }\end{array}$} \\
\hline & & & \multicolumn{3}{|r|}{ Signature of Reviewer and Date } \\
\hline $\begin{array}{l}\text { Item } \\
\text { No. }\end{array}$ & \multicolumn{2}{|c|}{ Reviewer's Comments and Recommendation } & $\begin{array}{l}\text { Reqd. } \\
\text { (Y/N) }\end{array}$ & $\begin{array}{l}\text { Item } \\
\text { No. }\end{array}$ & Author's Response (if required) \\
\hline 1 & \multicolumn{2}{|c|}{$\begin{array}{l}\text { Sections } 2.3 \text { and 2.4: the subject of the second paragraph of Section } 2.3 \\
\text { and the first paragraph of Section } 2.4 \text { is very similar and while these two } \\
\text { paragraphs begin in identical ways, the material presented in the middle of } \\
\text { each paragraph can be considered contradictory. Specifically, Section } 2.4 \\
\text { states that cover compliance will be based on the soil moisture content of } \\
\text { the cover once steady-state conditions are reached and that it is expected } \\
\text { to be achieved within } 10 \text { years of cover construction, which was } \\
\text { completed in September } 2000 \text {, as per cover performance modeling } \\
\text { presented in the Corrective Action Plan. Section } 2.3 \text { does not state a } \\
\text { timeframe for the soil moisture in the cover to reach equilibrium, only that } \\
\text { specific cover compliance criteria will not be set until it is reached. Both } \\
\text { paragrpahs do state that once equilibrium has been reached, soil moisture } \\
\text { compliance values will be agreed upon with the NDEP however, both } \\
\text { Sections should be worded consistetenly. }\end{array}$} & & 1 & Section 2.3, second paragraph has been deleted. \\
\hline 2 & \multicolumn{2}{|c|}{$\begin{array}{l}\text { Page 3-2, Section 3.2.1, second paragraph, thrid sentence: "SM-2, SM-3, } \\
\text { and SM-4, show" The SM-4 should be SM- } 5 \text {. Please correct this in the } \\
\text { sentence }\end{array}$} & & 1 & $\begin{array}{l}\text { Page 3-2, Section 3.2.1, second paragraph, fourth sentence now } \\
\text { states, "The northern monuments, SM-2, SM-3, and SM-4, along } \\
\text { with the western-most monument, SM-5, show the least }\end{array}$ \\
\hline
\end{tabular}




\section{U.S. Department of Energy Office of Legacy Management}

\section{Record of Review (continuation)}

\begin{tabular}{|c|c|c|c|c|}
\hline Review No. & \multicolumn{4}{|l|}{ Project } \\
\hline \multirow[t]{2}{*}{$\begin{array}{l}\text { Item } \\
\text { No. }\end{array}$} & Reviewer's Comments and Recommendation & $\begin{array}{l}\text { Reqd. } \\
\text { (YIN) }\end{array}$ & $\begin{array}{l}\text { Item } \\
\text { No. }\end{array}$ & Author's Response (if required) \\
\hline & & & & $\begin{array}{l}\text { subsidence because of the thinner layer of underlying mud along } \\
\text { this margin of the cover." }\end{array}$ \\
\hline 3 & $\begin{array}{l}\text { Section } 3.2 .2 \text { and Figure } 3.3: \text { It is stated in Section } 3.2 .2 \text { that the total } \\
\text { subsidence of the west monument is } 6.6 \mathrm{~cm}(2.6 \text { in) and the east } \\
\text { monument, } 3.1 \mathrm{~cm}(1.2 \text { in) since the baseline survey in October } 1999 \text {. } \\
\text { Figure } 3.3 \text { depicts the subsidence of the west monument as approximately } \\
0.6 \mathrm{~m} \text { or } 2.6 \text { inches but the east monument as approximately } 0.9 \text { mor } \\
3.85 \text { inces. The text of Section } 3.3 .3 \text { and Figure } 3.3 \text { should be in } \\
\text { agreement. }\end{array}$ & & 3 & $\begin{array}{l}\text { Figure 3.3: The east subsidence marker's graphical } \\
\text { representation was incorrect and has been corrected. }\end{array}$ \\
\hline 4 & $\begin{array}{l}\text { Page 3-6, Table 3-2 and Page 3-7, Figure 3-3: The values for east } \\
\text { monument subsidence presented in Table 3-2 are not reflected in the plot } \\
\text { in Figures 3-3. Please correct this discrepancy. }\end{array}$ & & 4 & $\begin{array}{l}\text { Figure 3.3: The east subsidence marker's graphical } \\
\text { representation was incorrect and has been corrected. }\end{array}$ \\
\hline 5 & $\begin{array}{l}\text { Page 3-8, Section 3.4, third paragraph, first sentence: There is no Figure } \\
4-1 \text { in the document. The } 2007 \text { precipitation is presented in Figure } 3-4 \text {. } \\
\text { Please correct this in the document. }\end{array}$ & & & $\begin{array}{l}\text { Page } 3-8 \text {, Section } 3.4 \text {, third paragraph, first sentence: Figure 4- } \\
1 \text { has been changed to Figure } 3-4 \text {. }\end{array}$ \\
\hline 6 & $\begin{array}{l}\text { Section } 4.1 \text { and Section C3.0: It is suggested in the second paragraph of } \\
\text { Section } 4.1 \text { that future vegetation surveys be conducted once every } 2 \\
\text { years or as needed to help monitor the health of the vegetation. The last } \\
\text { paragraph of Section C3.0 also conveys this recommendation. This } \\
\text { recommendation was presented in the Post-Closure Inspection and } \\
\text { Monitoring Report for Calendar Year } 2006 \text { and approved by the NDEP in } \\
\text { a letter dated August } 2,2007 \text {. The NDEP still accepts this } \\
\text { recommendation and expects that a vegetation survey will be conducted } \\
\text { during the } 2008 \text { inspection. }\end{array}$ & & & $\begin{array}{l}\text { Currently, a vegetation survey is being conducted every two } \\
\text { years. Due to the timing of the NDEP response approving this in } \\
\text { August } 2007 \text {, the DOE had already performed a vegetation } \\
\text { survey in } 2007 \text {. The next vegetation survey will be in } 2009 \text {. }\end{array}$ \\
\hline 7 & $\begin{array}{l}\text { Section 4.3: The first three Recommendations were presented in the } \\
\text { Post-Closure Inspection and Monitoring Report for Calendar Year } 2006 \\
\text { and approved by the NDEP in a letter dated August 2, 2007. The NDEP } \\
\text { still accepts these recommendations. }\end{array}$ & & & No comment required. \\
\hline 8 & $\begin{array}{l}\text { Section 4.3: In regards to the last two Recommendations presented in the } \\
\text { Report, the NDEP concurs with meeting with the Office of Legacy } \\
\text { Management (OLM) to discuss the closure plan with respect to historical } \\
\text { site data collected, present site condition, including the non-working east } \\
\text { TDR nest, and future path forward. In the meantime, OLM should } \\
\text { continue to collect data from the east TDR nest if at all possible. It is the } \\
\text { NDEP's belief that while it may now be thought to be uselss data, it may } \\
\text { become valuable in the future. Once OLM has established soil moisture }\end{array}$ & & & $\begin{array}{l}\text { East and west TDR data are still being collected. The lower } \\
\text { depths of the east TDR nest contain so much "noise" the data } \\
\text { collected from these lower zones are not useable. }\end{array}$ \\
\hline
\end{tabular}




\section{U.S. Department of Energy Office of Legacy Management}

Record of Review (continuation)

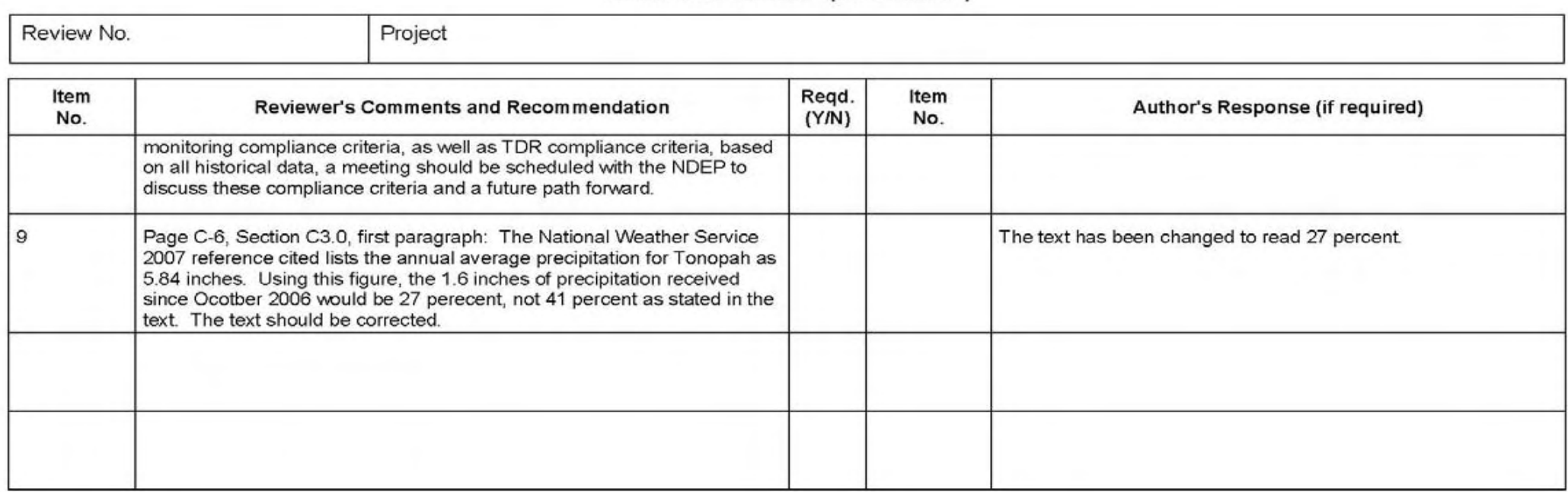


This page intentionally left blank 